\title{
A Guide to Targeting the Endocannabinoid System in Drug Design
}

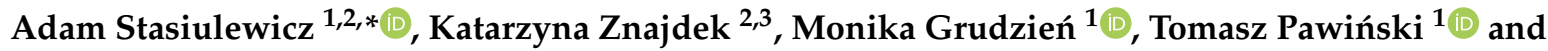 \\ Joanna I. Sulkowska $2,4,5, *$ \\ 1 Department of Drug Chemistry, Faculty of Pharmacy, Medical University of Warsaw, Banacha 1, \\ 02-097 Warsaw, Poland; monika.grudzien@wum.edu.pl (M.G.); tomasz.pawinski@wum.edu.pl (T.P.) \\ 2 Interdisciplinary Laboratory of Biological Systems Modelling, Centre of New Technologies, \\ University of Warsaw, Banacha 2c, 02-097 Warsaw, Poland; k.znajdek@cent.uw.edu.pl \\ 3 Faculty of Pharmacy, Medical University of Warsaw, Banacha 1, 02-097 Warsaw, Poland \\ 4 Faculty of Chemistry, University of Warsaw, Pasteura 1, 02-093 Warsaw, Poland \\ 5 Materials and Process Simulation Center, California Institute of Technology, Pasadena, CA 91125, USA \\ * Correspondence: a.stasiulewicz@cent.uw.edu.pl (A.S.); j.sulkowska@cent.uw.edu.pl (J.I.S.)
}

Received: 16 March 2020; Accepted: 14 April 2020; Published: 16 April 2020

\begin{abstract}
The endocannabinoid system (ECS) is one of the most crucial systems in the human organism, exhibiting multi-purpose regulatory character. It is engaged in a vast array of physiological processes, including nociception, mood regulation, cognitive functions, neurogenesis and neuroprotection, appetite, lipid metabolism, as well as cell growth and proliferation. Thus, ECS proteins, including cannabinoid receptors and their endogenous ligands' synthesizing and degrading enzymes, are promising therapeutic targets. Their modulation has been employed in or extensively studied as a treatment of multiple diseases. However, due to a complex nature of ECS and its crosstalk with other biological systems, the development of novel drugs turned out to be a challenging task. In this review, we summarize potential therapeutic applications for ECS-targeting drugs, especially focusing on promising synthetic compounds and preclinical studies. We put emphasis on modulation of specific proteins of ECS in different pathophysiological areas. In addition, we stress possible difficulties and risks and highlight proposed solutions. By presenting this review, we point out information pivotal in the spotlight of ECS-targeting drug design, as well as provide an overview of the current state of knowledge on ECS-related pharmacodynamics and show possible directions for needed research.
\end{abstract}

Keywords: endocannabinoid system; ECS; CB1; CB2; FAAH; MAGL; molecular target

\section{Introduction}

Cannabis sativa has been used for medical and recreational purposes for millennia [1]. The attention this plant has been a subject of resulted in the exploration of the way it influences the human organism. This opened a new chapter in modern pharmacology. The isolation of main constituents of Cannabis, $\Delta$ 9-tetrahydrocannabinol ( $\triangle 9$-THC) and cannabidiol (CBD) in the 1960s [2] led to the latter discovery of cannabinoid receptors (CB receptors or CBRs) [3-5] and to the identification of their endogenous ligands [6,7]. This initiated wide research on this biological system, called the endocannabinoid system (ECS). Today, we know that ECS comprises cannabinoid receptors type 1 and 2 (CB1 and CB2), their endogenous ligands - endocannabinoids (eCBs), enzymes, transporters, and other receptors. In this review, we will show the way in which the proteins of ECS may be possibly targeted in the treatment of various diseases and disorders. We will highlight recent, prominent studies, the most promising strategies, and the most interesting directions one could follow in ECS-related drug design. 
The discovery of cannabinoid receptors and endocannabinoids began the extensive research on this newly found physiological system. The considerable expansion of knowledge on ECS during the last few decades resulted in a paradigm shift. ECS, despite being named after a psychoactive plant, is in fact a very important system in the human organism. CB1 is among the most abundant receptors in the central nervous system (CNS), and is a major regulatory factor for multiple neurons, including glutaminergic, GABAergic, dopaminergic, etc. [8]. Additionally, CB1 is present in many important peripheral organs and tissues, while CB2 is most notably in immune cells [9]. Thus, ECS takes part in a vast array of physiological processes and functions, including: mood regulation, pain management, cognitive functions, reward, appetite, fat and glucose metabolism, neurogenesis and neuroprotection, inflammation and immune functions, smooth muscle contractility, cell proliferation, and many others (Figure 1A). Thus, ECS has been viewed as a potential therapeutic target in multiple diseases and disorders. Compounds aiming proteins of ECS have been used or studied as a treatment of pain, seizures, psychiatric disorders, obesity, metabolic diseases, neurodegenerative diseases, and cancer. Alas, to date, these attempts have not achieved the desired success.

ECS is a complex system that has major implications for the safety of pharmacotherapy. The multi-directional character of this system poses a threat of adverse effects. The most notorious example is rimonabant-a CB1 inverse agonist used as an anti-obesity agent. Drugs containing rimonabant were approved in Europe in 2006. Alas, they exhibited major psychiatric adverse effects, including anxiety and depression, and in some cases led to consequent suicides. Those drugs were withdrawn in 2008 [10]. On the superficial level, the idea was logical: decreasing CB1 signaling reduces appetite and fat accumulation. Unfortunately, a multi-purpose nature of ECS was neglected. Downregulation of CB1 signaling is known to negatively alter mood and emotional state, and this knowledge was available even before the approval of the drugs containing rimonabant [11]. Thus, when designing drugs targeting ECS components, one has to bear in mind the possible multi-directional effects, which may be beneficial or deleterious depending on the specific ECS-targeting drug. In addition, downregulation of endocannabinoid signaling has to be planned with caution, as ECS is crucial for regulating many physiological functions.

Analogically, activation of cannabinoid receptors may be a powerful therapeutic strategy. However, it also comes with several obstacles which may be illustrated with the instance of Cannabis sativa. This plant is recently going through a renaissance, with a considerable increase in its medical use. It seems to be a valuable alternative for some drugs. Unfortunately, the therapeutic profile of Cannabis is not perfect. Although the administration of this medicinal plant's preparations is generally well tolerated, in some cases, it may lead to possible risks of addiction, various adverse effects, and cognitive dysfunctions due to a long-term therapy [12]. Additionally, the efficacy of the use of Cannabis in several indications is constantly discussed. For example, the results of clinical trials regarding therapy of chronic pain are inconclusive $[13,14]$. Though Cannabis sativa seems to be a promising direction, cannabinoids with a potentially better pharmacological profile have been sought in other plants in recent years. For example, CB1 ligands were found in Daucus carota, Piper methysticum, and Heliopsis helianthoides. However, these phytocannabinoids have low to moderate affinities towards CB1, in some cases unknown intrinsic activities, and in most instances clinical applicability yet to be determined [15]. Thus, more research is needed in this area, and so far Cannabis holds its reign in the field. Nevertheless, the problems this plant faces show the importance of considering typical adverse effects caused by CB1 activation, and highlight the necessity of avoiding them in modern ECS-related drug design. 

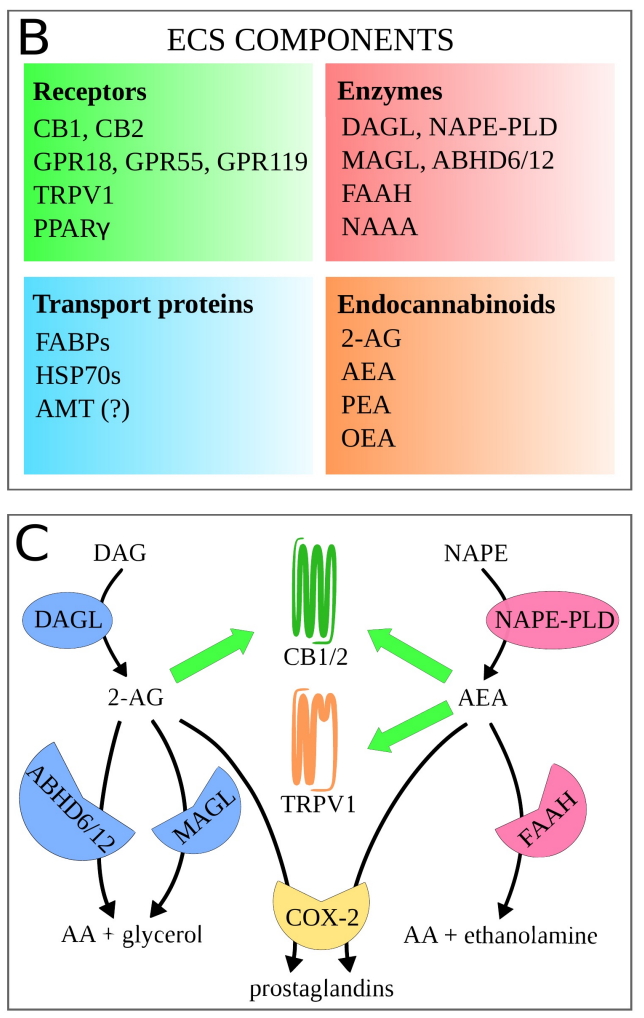

\section{A}

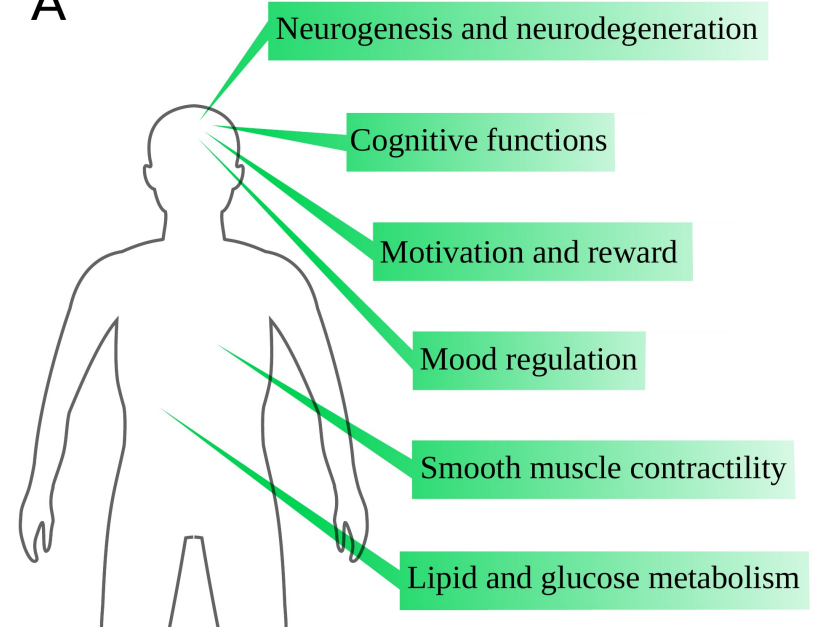

Appetite

Inflammation

Nociception

Cell growth and proliferation

Figure 1. (A) physiological processes and functions that the endocannabinoid system (ECS) takes part in. In this figure, we gathered probably the most crucial ones in terms of potential therapeutic applications, described in detail in this review; (B) components of the ECS; (C) simplified biochemical pathways of the two main endocannabinoids: 2-arachidonoylglycerol (2-AG) and N-arachidonoylethanolamine, also called anandamide (AEA). Blue shapes depict enzymes associated mainly with 2-AG, pink ones-with AEA. Green arrows indicate activation of specific receptors by the endocannabinoids. Abbreviations: 2-AG, 2-arachidonoylglycerol; AA, arachidonic acid; ABHD6/12, $\alpha / \beta$ hydrolase domain 6 or 12; AEA, N-arachidonoylethanolamine (anandamide); AMT, anandamide membrane transporter; $\mathrm{CB} 1 / 2$, cannabinoid receptor type 1 or 2; COX-2, cyclooxygenase 2; DAG, diacylglycerol; DAGL, diacylglycerol lipase; FAAH, fatty acid amide hydrolase; FABPs, fatty-acid-binding proteins; GPR18/55/119, G protein-coupled receptor 18 or 55 or 119; HSP70s, 70 kilodalton heat shock proteins; MAGL, monoacylglycerol lipase; NAAA, N-acylethanolamine acid amidase; NAPE, N-acylphosphatidylethanolamine; NAPE-PLD, N-acylphosphatidylethanolamine-hydrolyzing phospholipase D; OEA, oleoylethanolamine; PEA, palmitoylethanolamide; PPAR $\gamma$, peroxisome proliferator-activated receptor $\gamma$; TRPV1, transient receptor potential vanilloid type 1 channel.

Because of numerous problems that ECS targeting creates, which we illustrated in the above examples, this system is sometimes referred to as "undruggable". This concept was proved to be entirely wrong by some drugs known for a long time. The best example would be paracetamol (acetaminophen)_one of the most often used drugs all over the world. It was initially believed to act similarly to nonsteroidal anti-inflammatory drugs (NSAIDs) and was studied for its potential impact on the prostanoid system [16-18]. Today, we know that it has a complex mechanism of action (MOA) and acts via cyclooxygenase 3 (COX-3) inhibition [19], serotonin receptor 3 (5-HT3) antagonism [20,21], nitric oxide synthase (NOS) inhibition [22], and CB1 agonism [23]. In 2006, Ottani et al. showed that the latter mechanism may be the most important one for paracetamol's properties. They blocked CB1 with two antagonists-SR141716A and AM281. In both cases, paracetamol's analgesic activity was prevented [23]. In 2017, Sharma et al. proved that paracetamol is metabolized in vivo to $\mathrm{N}$-arachidonoylaminophenol (AM404) [24], which is the anandamide reuptake inhibitor [25], as well as weak CB1 [26] and TRPV1 agonist [27]. Another analgesic, metamizole (dipyrone), was also found 
to act via ECS [28,29]. Fenofibrate, a peroxisome proliferator-activated receptor $\alpha$ (PPAR $\alpha$ ) agonist, was proved to be a CB1 and $\mathrm{CB} 2$ agonist and at higher concentrations a $\mathrm{CB} 1$ negative allosteric modulator (NAM) [30].

The story of drugs acting via ECS does not end at the known drugs with unknown endocannabinoid MOA. The pursuit of novel ECS-targeting compounds continues. The involvement of ECS in multiple physiological processes provides an immense therapeutic potential that remains hard to be given up. Additionally, recent elucidation of CB1 [31] and CB2 [32] tertiary structures creates a new stimulus for the design of novel ligands for these two important receptors. Moreover, the knowledge on ECS physiology is constantly growing, allowing us to better understand chances and risks in targeting this system. It is worth mentioning that endocannabinoids also play a role in the pathophysiology of various diseases and disorders, thus making the ECS even more desired target. As in this review, we focus on the proteins of ECS; the readers are directed to other recent reviews which focus on eCBs' biochemistry [33] and their impact on specific pathological conditions [34]. Because of all these factors, there have been numerous attempts and proposed solutions to overcome aforementioned difficulties. The best known of these proposals include: (1) development of peripheral CB1 agonists that do not cross the blood-brain barrier, and therefore do not cause typical phytocannabinoid-like adverse effects; (2) using CB1 neutral antagonists instead of inverse agonists or CB1 peripheral antagonists/inverse agonists to avoid rimonabant-like adverse effects. These are sometimes called the "second generation" of synthetic cannabinoids [35]. In this review, we cover and highlight these and many more proposals for possibly effective and safe ECS targeting, with the division for pathophysiological areas, in which drugs could potentially be used. We also stress possible benefits and risks, and limitations of the state of knowledge on the involvement of specific molecular targets in potential applications. The data gathered in this review may be treated as a signpost. It enables the rational selection of a molecular target for drug design. In addition, it gathers information on the involvement of ECS in various physiological functions and diseases in one place and shows possible directions for much needed research.

\section{Endocannabinoid System}

ECS comprises cannabinoid receptors type 1 and 2 (CB1 and CB2), their endogenous ligands-endocannabinoids (eCBs), and enzymes responsible for $\mathrm{eCBs}^{\prime}$ synthesis and degradation (Figure 1B). eCBs include two main ones: 2-arachidonoylglycerol (2-AG) and $\mathrm{N}$-arachidonoylethanolamine, better known as anandamide (AEA), but also palmitoylethanolamide (PEA), oleoylethanolamine (OEA), and others [36]. Simplifying, 2-AG is synthesized by diacylglycerol lipase (DAGL) and degraded by monoacylglycerol lipase (MAGL or MGL) and $\alpha / \beta$ hydrolase domain 6 and 12 (ABHD6 and ABHD12) [37]. AEA is synthesized by $\mathrm{N}$-acylphosphatidylethanolamine-hydrolyzing phospholipase D (NAPE-PLD) and degraded by fatty acid amide hydrolase (FAAH) [38] (Figure 1C). Additionally, there are other proteins involved in ECS. AEA is transported by fatty-acid-binding proteins (FABPs), 70 kilodalton heat shock proteins (HSP70s), and probably anandamide membrane transporter (AMT), although AMT's existence has not been directly proven [38]. Apart from CB1 and CB2, eCBs also bind to other proteins, most notably to G protein-coupled receptor (GPCR) 18 (GPR18) [39], GPR55 [40], GPR119 [41], transient receptor potential vanilloid type 1 (TRPV1) channel [42], and peroxisome proliferator-activated receptor $\gamma$ (PPAR $\gamma$ ) [43]. As some of these are parts of other physiological systems [44], it is hard to define the borders of ECS. Therefore, we will focus on core proteins of ECS, but will also cover others when it is necessary.

\section{Molecular Mechanisms of the Main Proteins of ECS—Implications for Drug Design}

Targeting the specific proteins of ECS also requires knowledge of basic concepts and nuances in their pharmacology at a molecular level. As this is a very broad topic, and there are many research articles and reviews regarding this area [45-48], we will limit this section to information that is crucial 
for understanding consecutive parts and will highlight the concepts vital for modern ECS-related drug design.

The main proteins of ECS, CB1 and CB2 are G protein-coupled receptors. As such, their ligands are characterized with both binding affinity and intrinsic activity. It is important that CBRs exhibit constitutive activity $[49,50]$, and thus their ligands' intrinsic activities vary from agonist, through partial agonist and antagonist, to inverse agonist. As up and downregulation of ECS-mediated signaling are desired in specific pathophysiological conditions, CBRs agonists and antagosists/inverse agonists may act as drugs. In the case of CB1, the distinction between antagonists and inverse agonists is especially important because of the psychiatric adverse effects of the latter. It is believed that these difficulties may be overcome by utilization of CB1 antagonists [51]. Antagonists are sometimes referred to as "neutral" in order to emphasize that a compound is an antagonist, not an inverse agonist.

CBRs are coupled mainly to $\mathrm{G}_{\mathrm{i} / \mathrm{o}} \alpha$ subunits $\left(\mathrm{G} \alpha_{\mathrm{i} / \mathrm{o}}\right)$. Upon agonist binding, or constitutively, the receptor's conformation changes from inactive to active. This allows for exchanging guanosine diphosphate (GDP) for guanosine triphosphate (GTP) on the $\alpha$ subunit of the G protein. Then, $\mathrm{G} \alpha$ dissociates from $\mathrm{G} \beta \gamma$ dimer and from the CBR. $\mathrm{G} \alpha$ inhibits adenylyl cyclase (AC) and subsequently the cyclic adenosine monophosphate (cAMP)-dependent pathway. $\mathrm{G} \beta \gamma$ regulates mitogen activated protein kinases (MAPKs). Additionally, G $\beta \gamma$ of CB1 affects calcium and potassium channels [52]. However, CBRs bind also to other $\mathrm{G}$ protein types and to non-G proteins, most notably $\beta$-arrestin, and thus CBRs' activation may lead to the onset of various signaling pathways [53]. The occurrence and ratios of different messenger proteins depend heavily on their expression which is tissue- or cell-specific [53,54]. Thus, it is important to explore the possibilities of designing site-specific CBRs agonists and/or delivery systems. Moreover, CBRs exhibit biased signaling, which means that structurally diverse agonists stabilize different ranges of active conformations of the receptors, and consequently lead to a preference for activation of different biochemical pathways [53]. Development of CB1 biased agonists may be possibly a valid strategy to avoid phytocannabinoid-like adverse effects [55].

Another possible way to design potential CBRs-targeting drugs with desired pharmacological profile is the utilization of the allostery. Both CB1 and CB2 comprise probably a few allosteric binding sites [56-58]. Allosteric modulators may have a few advantages in comparison to the orthosteric ligands. Allosteric binding sites in GPCRs are less conserved than orthosteric ones, thus simplifying the design of selective compounds [59]. Allosteric modulators act in the presence of the orthosteric ligands, including eCBs. Thus, allosteric modulators retain the spacial and temporal nature of the endocannabinoid signaling. This implicates several possible pharmacodynamical advantages, including: not exhibiting constant and long lasting activation or inhibition, saturability (ceiling effect), and potential for lesser CBR desensitization or downregulation. These features may result in reduction of the risks of adverse effects, behavioral tolerance, and overdosing [60-63]. Moreover, it was shown that CBRs' allosteric modulators may also exhibit biased signaling [64,65].

Although CB1 and CB2 are the most extensively studied proteins of ECS, there are also important factors regarding other molecular targets. In the case of eCB degrading enzymes, MAGL and FAAH, it is important to distinguish between reversible and irreversible inhibition [66,67]. For MAGL, it was shown that its irreversible inhibitors, through prolonged inactivation of this enzyme, may cause physical dependence, CB1 desensitization, and impaired eCB-dependent synaptic plasticity [68]. Moreover, MAGL and FAAH form homodimers [66,69]. Recently, FAAH dimers have been proven to be dependent on the signaling between their subunits and its allosteric regulation. Thus, it may be possible to design allosteric modulators of FAAH [69]. TRPV1 is a non-selective channel. It may be activated by ions, capsaicin, and other chemical or physical stimuli. Some of these stimuli allosterically control the transition from close to open conformation of TRPV1, importantly through different allosteric paths and distinct conformational changes [70,71]. This characteristic may be utilized in order to design TRPV1 allosteric modulators with specific allosteric mechanisms, and thus lacking typical adverse effects [47]. 


\section{Nervous System}

\subsection{Pain}

Today, the endocannabinoid system is an obvious and well-established target for the therapy of pain. ECS is a part of an endogenous antinociceptive system. Activation of CBRs in peripheral, spinal, and supraspinal neurons suppresses nociceptive transmission. Moreover, CBRs are present in immune cells and regulate inflammatory responses [72,73]. Thus, CBRs' ligands may be a valuable alternative or adjunctive to opioids [74]. However, the administration of drugs targeting the ECS, especially CB1, comes with a risk of cognitive adverse effects [75] or disruption of ECS regulation of reward system [76,77]. One of the strategies to avoid the aforementioned obstacles is to design ligands acting only on peripheral CB1. Recently developed 4-2-[-(1E)-1[(4-propylnaphthalen-1-yl)methylidene]-1H-inden-3-yl]ethylmorpholine (PrNMI) is an example of a peripherally restricted cannabinoid (PRCB). In rat model $(0.25 \mathrm{mg} / \mathrm{kg})$, it suppressed chemotherapy-induced peripheral neuropathy (CIPN) allodynia via CB1 agonism [78]. Another possible way to avoid CB1-related adverse effects is modulating CB1 allosterically which was achieved by GAT211 - a new CB1 positive allosteric modulator (PAM). It showed efficacy in inflammatory and neuropathic pain models in mice $(10-20 \mathrm{mg} / \mathrm{kg})$. Additionally, it did not create physical dependence and its therapeutic efficacy, without tolerance, was maintained for a longer time than for CB1 orthosteric agonists or MAGL inhibitors [79].

There is also an increasing number of research on CB2 impact on nociception. Some evidence aims especially at neuropathic pain, for which CB2 on microglia and CNS-infiltrating macrophages plays an important role [80]. Recently, the first positive allosteric modulator of CB2 has been synthesized and exhibited antinociceptive activity (5-20 $\mathrm{mg} / \mathrm{kg}$ ) in a rodent neuropathic pain model [81].

In addition, other proteins of ECS are targeted in the fight against pain. The selective MAGL inhibitor, ABD-1970 (1-2 mg/kg), displayed antinociceptive and antipruritic activity in a rodent model, without causing typical cannabinoid adverse effects [82]. Selective FAAH inhibitors (10 mg/ $\mathrm{kg}$ ) were shown to be effective against neuropathic pain in mice [83]. However, the increase in AEA levels by FAAH inhibition leads not only to CB1 activation and consequent analgesic effect. Activation of presynaptic TRPV1 by AEA exhibits pro-nociceptive activity. Additionally, AEA is metabolized also to pro-inflammatory prostaglandins (PG) by COX. Therefore, dual FAAH/TRPV1 and FAAH/COX-2 inhibitors are proposed for the therapy of pain [84].

As ECS is an abundant system, it interacts and cooperates with other pharmacological systems and crosses other biochemical pathways. This is important in terms of mechanisms of action of several antinociceptive drugs. Ketamine, a non-competitive N-methyl-D-aspartate (NMDA) receptor antagonist, was found to act also via ECS. CB1 antagonist, AM251 (2-4 $\mu \mathrm{g}$ intracerebroventricularly), completely prevented ketamine's $(4 \mu \mathrm{g})$ central antinociception in rodent model. On the other hand, the inhibition of AEA reuptake by VDM11 $(4 \mu \mathrm{g})$ increased antinociception caused by a low dose of ketamine $(2 \mu \mathrm{g})$ [85]. Indomethacin morpholinamide (IMMA) $(10 \mathrm{mg} / \mathrm{kg})$, a novel COX-2 inhibitor, successfully reduced hyperalgesia and allodynia in the rodent model. CB2 antagonist, AM630 $(3 \mathrm{mg} / \mathrm{kg}$ intraperitoneally), partially reversed IMMA's action. This compound has a complex MOA, including reduction in prostaglandin $E_{2}$ (PGE2) synthesis and CB2 activation [86]. Other studies focused on aripiprazole, an antypsychotic drug and a ligand of multiple dopamine (DA) and serotonin (5-HT) receptors. It was shown that aripiprazole $(0.1-10 \mathrm{mg} / \mathrm{kg}$ intraperitoneally) exhibits antinociceptive action in a rodent model [87]. In mice, aripiprazole's $(0.1 \mathrm{mg})$ antinociceptive activity was prevented by both $\mathrm{CB} 1$ and $\mathrm{CB} 2$ antagonists. On the other hand, pain-relieving effects of aripiprazole were enhanced by co-administration of FAAH inhibitor, MAGL inhibitor, and AEA reuptake inhibitor [88]. Moreover, a case study on psychiatric patients showed that aripiprazole (2.5-15 mg/day) may exhibit antinociceptive action also in humans [89]. However, more research is needed in this area. 


\subsection{Seizures}

There is a constant debate on the possible use of Cannabis sativa and its constituents in seizures and epilepsy. Although this subject seems to be still open, it is a fact that ECS can impact aforementioned conditions [90]. CB1 agonists, such as WIN55,212, decreased seizure severity in rodent models. It has been shown that CB1 acts synergistically with 5-HT2B receptor, as co-administration of WIN55,212 (2 mg/ kg, intraperitoneally) and 5-HT2B agonist RO60-0175 (3 mg/kg, intraperitoneally) decreased seizure severity and additionally reduced the incidence of seizures, while RO60-0175 (1-10 $\mathrm{mg} / \mathrm{kg}$, intraperitoneally) had no effect on its own [91]. The other possible direction is MAGL or FAAH inhibition. Although the increase in 2-AG and AEA levels should logically be connected with anti-seizure activity via CB1, recent studies on rodents indicate that only MAGL inhibition (e.g., JJKK048-1 mg/ $\mathrm{kg}$ ) results in anti-seizure activity, with 2-AG activating CB1 [92]. FAAH inhibition (e.g., URB597-80-160 $\mu \mathrm{g}$ intracerebroventricularly) leads to the increase in intracellular AEA levels, consequent TRPV1 activation and finally to pro-seizure activity [93,94]. On the other hand, anandamide reuptake inhibitor, LY21813240 $(2.5 \mathrm{mg} / \mathrm{kg})$, exhibited anti-seizure effects mediated by CB1 in the rodent model [92]. Therefore, it is important to distinguish between the increase in extracellular and intracellular levels of AEA. In addition, ABHD6 inhibitor, WWL70 (5 mg/ kg), led to anti-seizure activity in the rodent model, though contrary to MAGL inhibition, in a CB1-independent manner [92]. It is possible that this mechanism is connected with the ABHD6 regulation of $\alpha$-amino-3-hydroxy-5-methyl-4-isoxazolepropionic acid (AMPA) receptor [95]. Synaptic components of ECS are depicted in Figure 2.

Paracetamol is an analgesic and antipyretic drug. Interestingly, it was shown to exhibit anticonvulsant activity in vitro [96] and in rodent models (150-450 mg/ kg intraperitoneally). It was hypothesized that this activity may be caused by AM404, an active metabolite of paracetamol, known to inhibit AEA reuptake, and activate TRPV1 and CB1 [97]. A later study proved that paracetamol's anti-seizure activity in mice $(300-450 \mathrm{mg} / \mathrm{kg}$ intraperitoneally) is CB1-independent, as AM251 (CB1 inverse agonist) did not prevent this activity. Additionally, TRPV1 antagonists reduced paracetamol anticonvulsant activity. All this information suggests that in rodents paracetamol displays anti-seizure properties via indirect TRPV1 agonism (through AM404), although more research is needed [98]. The contrary results showing that both TRPV1 agonism and antagonism may exhibit anti-seizure activity could be caused by influencing TRPV1 in different parts of the brain or TRPV1 in presynaptic or postsynaptic neurons. Moreover, it is important to state that paracetamol does not exhibit anticonvulsant activity in humans. When targeting ECS in coping with epilepsy and seizures, it is crucial to note considerable differences in the effects of ECS modulation in different species [99].

In the area of seizures, the greatest success was achieved by CBD. Epidiolex, an oral solution containing CBD, is an approved drug, with indications for two forms of epilepsy: Lennox-Gastaut syndrome and Dravet syndrome [100] (see: Section 11. Approved drugs and clinical trials). CBD has a complex mechanism of action, including CB1 negative allosteric modulation, TRPV1 agonism, and GPR55 antagonism. Moreover, it is a 5-HT1A agonist and interacts with multiple other pharmacologically relevant proteins $[40,101-103]$. The exact mechanism of CBD anticonvulsant activity is not entirely clear $[104,105]$. However, there have been multiple studies regarding this matter and CBD probably exhibits its anti-seizure properties not by the impact on CB1 or TRPV1 but rather via GPR55, 5-HT1A, and other molecular targets [104]. Thus, it may be a valid direction to study GPR55 antagonists as potential antiseizure drugs. 


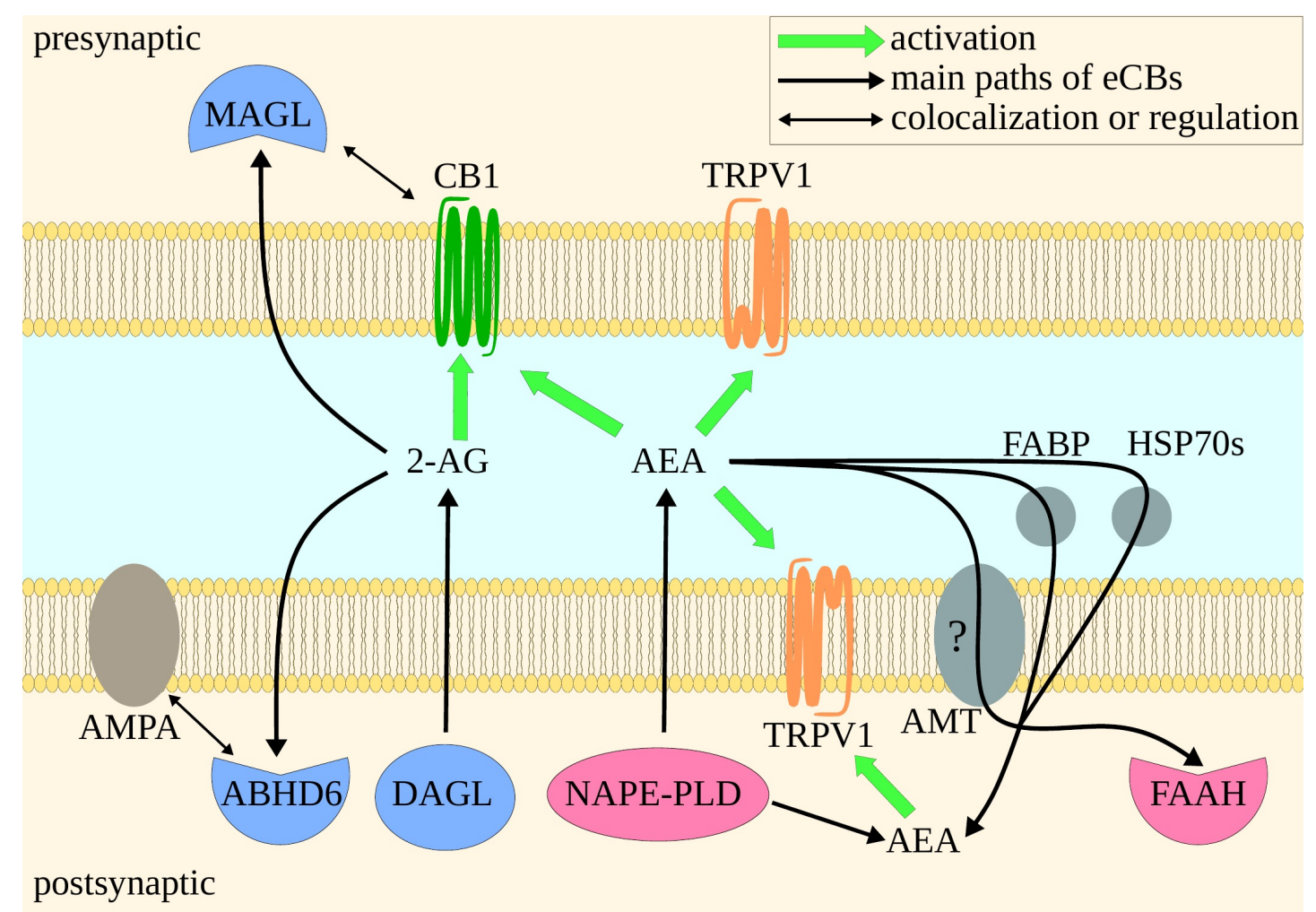

Figure 2. Simplified presentation of endocannabinoid signaling in the synaptic cleft. 2-AG is synthesized by DAGL in the postsynaptic neuron. After being excreted to the cleft, 2-AG activates presynaptic CB1. Finally, it is degraded by either MAGL in the postsynaptic neuron or by one of the ABHD's in the presynaptic one. MAGL is colocalized with CB1. ABHD6 regulates AMPA. This is probably important for CB1-independent anti-seizure activity of ABHD6 inhibitors [92,95]. AEA is synthesized by NAPE-PLD. AEA may activate both CB1 and TRPV1, although the latter case is more complex. AEA may act on postsynaptic and presynaptic TRPV1. FABP, HSP70s, and probably AMT take part in AEA reuptake. Blocking this transport may be a valid therapeutic strategy, as it increases AEA extracellular levels, and thus leads to proportionally stronger activation of presynaptic TRPV1 than normal. FAAH inhibition, on the other hand, leads eventually to activation of TRPV1 in both synaptic neurons $[93,94]$. Green arrows indicate activation of receptors. Bold black arrows show main paths of 2-AG and AEA. Thin black arrows depict colocalization of CB1 and MAGL, and regulation of AMPA by ABHD6. Proteins are colored depending on their functions: enzymes associated mainly with 2-AG (blue), enzymes associated mainly with AEA (pink), eCB reuptake proteins (gray).

\subsection{Anxiety}

ECS is known to be a vital system for emotional processing and mood control. It takes part in regulation of stress and anxiety [106]. This can be a major problem in terms of adverse effects of new synthetic compounds acting via ECS, as shown by rimonabant [10]. On the other hand, targeting ECS may be a valid strategy to design novel psychotropic drugs, including anxiolytics.

Rimonabant, a potent CB1 inverse agonist, was an active ingredient of approved drugs used as anti-obesity agents. Due to rimonabant's major psychiatric adverse effects, including depression and anxiety [10], those drugs were withdrawn. Additionally, several studies reported a link between downregulation of ECS with anxiety-like behaviors even before, also in the case of rimonabant itself $[11,107]$. Logically, CB1 agonists were believed to be a promising direction for developing a new class of anxiolytic drugs. Although cannabinoids are generally well tolerated, direct CB1 agonism in some cases may come with a risk of other psychotropic adverse effects [108-110]. Therefore, other ECS directions have been explored. 
One of the most prominent strategies is to inhibit eCB degrading enzymes, MAGL and FAAH, in order to indirectly activate CB1 by 2-AG and AEA, respectively. In a study on rodents, URB602, a MAGL inhibitor (300-1000 pM injection), reduced NMDA infusion-induced panic effects via CB1and CB2-dependent manner [111]. There is evidence on impact of FAAH activity on anxiety. FAAH overexpression in hippocampal CA1-CA3 glutamatergic neurons in a rodent model led to decreased AEA level in hippocampus, and resulted in anxiety-like behavior [112]. Certain FAAH genotypes result in increased activity of this enzyme, and in turn in reduced AEA levels [113,114]. Several recent studies target FAAH. URB597 $(0.3 \mathrm{mg} / \mathrm{kg})$, an FAAH inhibitor, proved to reduce anxiety in a CB1-dependent manner in a rodent model [115]. Another compound, PF-04457845 (4 mg/day), was tested in a human trial and showed an increase in recall of fear extinction memory and reduced negative effects of stress. Such molecules may be potentially used in the treatment of post-traumatic stress disorder (PTSD) [116]. Counterintuitively, FAAH overexpression in basolateral complex of amygdala (BLA) reduced anxiety-like behaviors. This may be connected with a lower AEA level increasing GABA transmission in BLA [117]. This is important information, as it shows the complexity of ECS and the importance of not only targeting a proper protein, but also its specific anatomical population.

ECS is also related to stress activation of hypothalamic-pituitary-adrenal axis (HPA). The administration of AEA ( $50 \mathrm{ng} / 5 \mu \mathrm{L}$ intracerebroventricularly) proved to decrease levels of corticosterone in rodent model. In hypothalamus, both CB1 and CB2 were involved. In adrenal gland, AEA's effects were caused by activation of TRPV1 [118]. Though CB1 antagonism usually leads to anxiety-like symptoms, it has been shown that CB1 antagonism in a specific region may have the opposite effect. Site specific CB1 antagonism (rimonabant- $0.15 \mu \mathrm{g} / 0.1 \mu \mathrm{L}$ ) in the lateral habenula $(\mathrm{LHb})$ reduced anxiety-like behavior in a rodent model [119].

\subsection{Depression}

ECS takes part in emotional regulation and, similarly to anxiety, downregulation of endocannabinoid signaling correlates with depressive behaviors [120]. The most important strategy to target ECS in depressive disorders is direct or indirect CB1 activation. WIN55,212-2, a CB1 and CB2 agonist, prevented anhedonia in a rodent model $(0.5 \mathrm{mg} / \mathrm{kg})$ [121]. New studies on ECS and depression show possible importance of CB2. Its deletion in dopaminergic neurons resulted in depressive behavior [122]. This opens up a possibility of targeting CB2 with agonists or using non-specific CB1 and CB2 agonists. Interestingly, a study on mice showed that the administration of either CB1 agonist ACPA $(1 \mathrm{mg} / \mathrm{kg})$, CB1 antagonist AM251 (1 mg/kg), CB2 agonist GP1a $(2 \mathrm{mg} / \mathrm{kg})$, or CB2 antagonist AM630 $(0.5 \mathrm{mg} / \mathrm{kg})$ had anti-depressive effects. Additionally, the co-administration of a small, ineffective dose of ketamine $(5 \mathrm{mg} / \mathrm{kg})$ with CB1 or CB2 antagonist led to antidepressant action [123]. Antidepressant effects of AM251 $(10 \mathrm{mg} / \mathrm{kg})$ had been shown before in rodent models [124]. It was suggested that antidepressant or depressogenic effects of CB1 antagonists may be dependent on time of administration of a drug, with chronic exposure favoring depression [120,125]. In addition, eCB degrading enzymes are targeted in depressive disorders. URB597 $(0.3 \mathrm{mg} / \mathrm{kg})$ - a FAAH inhibitor, prevented anhedonia in a rodent model [121]. Another FAAH inhibitor, PF3845 (10 mg/kg), decreased passive behavioral coping to acute stress in mice [126].

\subsection{Addictions}

ECS takes part in regulation of motivation and reward effects [77]. It is widely known that Cannabis sativa has a mild potential for addiction, caused mainly by activation of CB1 [127,128]. It may be both an inconvenience in drug design and a potential strategy for developing anti-addiction drugs.

CB1 inverse agonists may cause serious psychiatric adverse effects [11]. One of the possible ways to omit this problem is the design of CB1 neutral antagonists. AM4113 was tested in a rodent model of opioid addiction. It inhibited opioid self-administration, without rimonabant-like adverse effects (3-10 mg/kg/day) [129]. The same compound decreased also alcohol consumption in mice $(1-3 \mathrm{mg} / \mathrm{kg} /$ day) [130]. Another prominent strategy is the development of CB1 allosteric modulators. 
ORG27569 (1.0-5.6 mg/kg), a CB1 NAM, reduced cocaine and methamphetamine seeking behavior in rats [131]. However, the exact mechanism of this action is unknown. Moreover, it has been shown that this compound may act in CB1-independent manner [62,132]. Thus, the utilization of CB1 NAMs in the treatment of addictions requires more research. A study on mice showed interactions between CB1 and ghrelin receptor, as administration of CB1 peripheral inverse agonist JD5037 (3 mg/kg/day) led to the reduction in alcohol intake. This was prevented in rodents lacking ghrelin or its receptor. It suggests the important impact of peripheral CB1 in healthy mammals on addictions. Therefore, CB1 peripheral antagonism emerges as a valid strategy with the reduced risk of central adverse effects [133].

On the other hand, CB1 agonists may also be helpful in some cases, for example in withdrawal syndromes [134], as chronic exposure to drugs of abuse impairs eCB transmission [77]. CB1 positive allosteric modulators may prove to be useful in this area. ZCZ011 $(10-40 \mathrm{mg} / \mathrm{kg})$, a CB1 PAM, attenuated $\triangle 9$-THC withdrawal somatic symptoms in mice [135]. Additionally, ECS activation within insula by JZL184 (10 mg/kg), a MAGL inhibitor, via CB1-dependent manner helped to relieve abstinence-related affective symptoms in a rodent model [136]. Interestingly, physical exercise has been shown to increase eCB levels, and thus may also be implemented in the treatment of withdrawal syndromes $[137,138]$.

The second most prominent target in ECS for fighting addiction is the CB2. It was found, among others, in brain regions responsible for reward $[139,140]$. In the rodent model, the administration of CB2 antagonist, AM630 (1 mg/ $\mathrm{kg})$, increased ethanol intake, while CB2 agonist, JWH133 (1 mg/kg), had opposite effects [141]. Combining CB1 antagonism with CB2 agonism may be a reasonable strategy because of recent findings that opposing action on these two receptors has a synergistic effect on reward processing [142]. It has to be stressed that evidence for this approach is limited. However, it may be potentially beneficial to conduct more research on the co-administration of compounds with opposing actions on CBRs, and to consider combination drugs. Nevertheless, targeting CB2 requires caution. There is evidence that CB2 impact on addictions may be more complex. In a study on rodents, it was found that both CB2 agonism and antagonism reduced rewarding effects of alcohol, although through different mechanisms [143]. Therefore, more research is needed before considering CB2 as a safe target in the treatment of addictions.

\subsection{Cognitive Functions}

ECS involvement in cognitive functions is complex, and it is safe to say that ECS "regulates" learning and memory. There has been multiple evidence that CB1 activation impairs memory [144], while CB1 antagonists may enhance it [145]. For example, in traumatic brain injury (TBI), symptoms include impaired spacial learning and memory. This is connected with increased 2-AG levels. The administration of CB1 antagonist AM281 $(3 \mathrm{mg} / \mathrm{kg})$ ameliorated aforementioned symptoms in mice [146]. The same compound $(2.5-5 \mathrm{mg} / \mathrm{kg})$ also improved cognitive deficits caused by scopolamine in the rodent model [147]. Rimonabant $(1 \mathrm{mg} / \mathrm{kg})$ improved memory in Down syndrome mice [148]. Pregnenolone (2-6 mg/kg), an endogenous CB1 NAM, reduced memory impairment caused by $\triangle 9$-THC administration in rodent models [149].

On the other hand, several studies prove that ECS signaling activation may enhance cognitive functions. Recently, a study showed that low doses of $\Delta 9-\mathrm{THC}(3 \mathrm{mg} / \mathrm{kg} /$ day) improved cognitive performance of old mice by enhancing gene expression, in which CB1 was crucial. It shows that activation of this receptor is an example of hormesis, with high doses of agonists exhibiting deleterious and low doses-a beneficial effect on cognitive functions. Moreover, in the case of the modulation of CB1 transmission, the age is also a very important factor [150]. Additionally, patients using medicinal Cannabis improved their cognitive performance after chronic administration of this plant. In addition, functional magnetic resonance imaging showed positive changes in their brain activation patterns. However, clinical relevance of these findings remains to be clarified, as there are several concerns, e.g., concentrations of $\triangle 9-\mathrm{THC}$ and CBD, and their influence on the outcome in comparison to the recreationally used Cannabis [151]. The odd positive impact of ECS activation on cognitive 
enhancement may be also due to CB2 anti-inflammatory action [152] or the impact of emotional state on learning and memory, all of which are modulated by ECS [153-155]. Other directions of enhancing memory or learning in the ECS mediated manner include MAGL or FAAH inhibition. Interestingly, MAGL inhibitor, JZL184 (0.5 mg/kg), enhances memory consolidation via CB2-dependent manner in rats [156]. The FAAH inhibitor, URB597 $(0.3 \mathrm{mg} / \mathrm{kg} /$ day or $0.5 \mathrm{mg} / \mathrm{kg}$ intraperitoneally), does the same through both CB1 and CB2 activation in rodent models $[154,157,158]$. ECS's possible influence on the nervous system is presented in Table 1.

Table 1. Potential ECS-mediated ways to treat nervous system-related disorders.

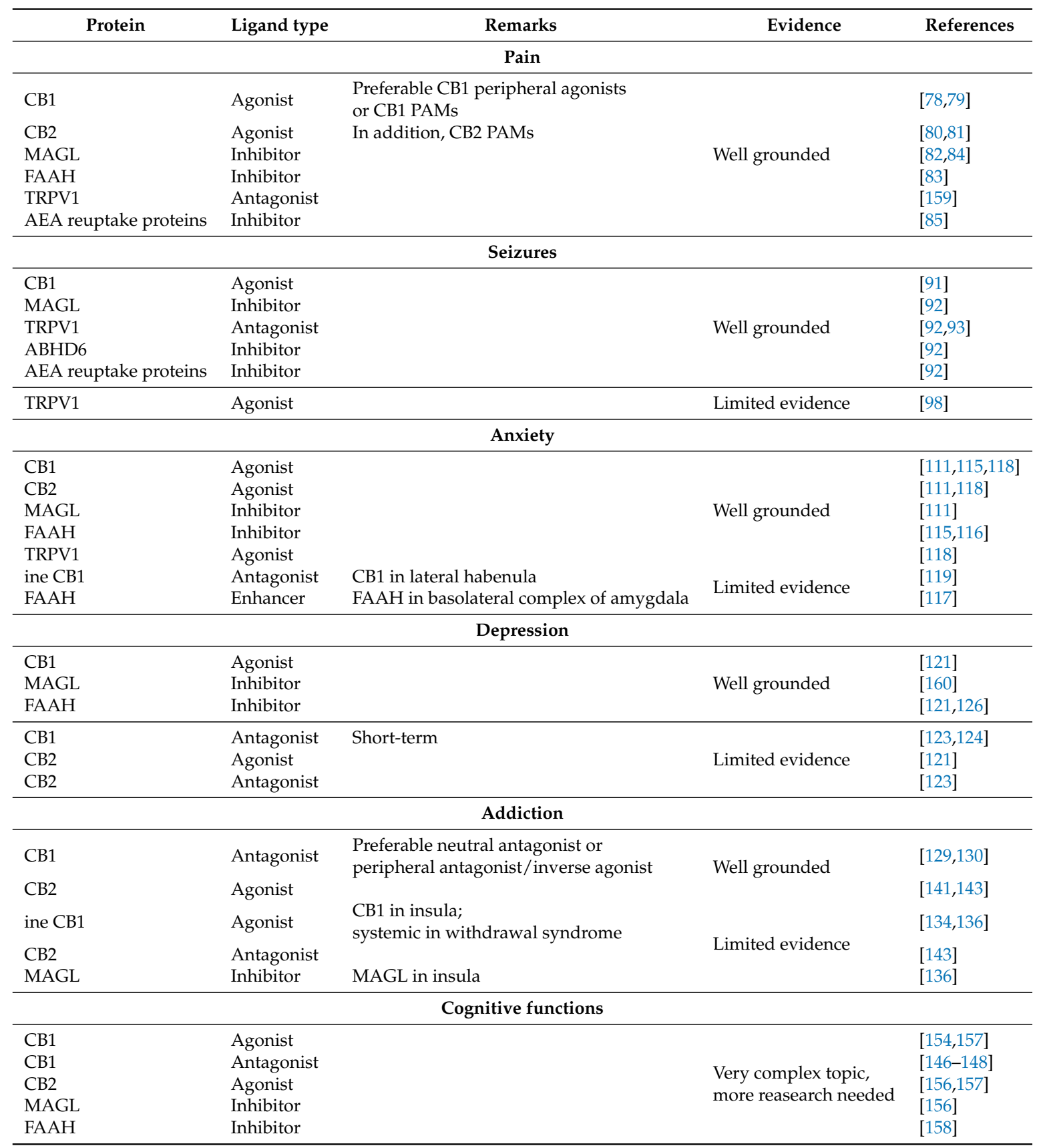

\section{Neurodegeneration}

ECS takes part in the regulation of neurogenesis and neurodegeneration [161]. Most studies suggest that endocannabinoid signaling is usually beneficial in this context. CB1, CB2, and GPR55 take 
part in the regulation of neurogenesis. CB1 and GPR55 are crucial for proliferation and differentiation of neural stem cells (NSCs) [162-164]. Additionally, CB1 and CB2 control the development of astrocytes [165]. Therefore, CB1, CB2, and GPR55 agonists, as well as MAGL inhibitors may be worth being investigated in the context of neurogenesis, although, to date, there is no solid evidence to legitimize such path.

Endocannabinoid signaling may also be beneficial because of its impact on attenuating neurotoxicity and neuroinflammation. It has been shown that deletion of CB1 accelerates brain aging through tumor necrosis factor $\alpha$ (TNF- $\alpha$ ) [166], while CB1 agonism decreases neuroinflammation [167]. There have also been studies on FAAH inhibition impact on decreasing neuroinflammation [168] and exitoxicity in rodent models [169]. Moreover, a GPR55 inverse agonist, KIT 17, in vitro inhibited PGE2 release in microglia (cells important for CNS immune functions), and thus may be further studied as a potential anti-neuroinflammatory agent [170]. As a system important for neuronal growth and death, ECS has been targeted in studies regarding Alzheimer's, Parkinson's, and Huntington's diseases, and others, such as amyotrophic lateral sclerosis (ALS).

In Alzheimer's disease (AD), it has been shown that CB1 deletion worsens the symptoms [171]. CB1 agonist, ACEA ( $3 \mathrm{mg} / \mathrm{kg}$ ), exhibited anti-apoptotic action on neurons and reduced cognitive impairment in the AD rodent model [172]. Lipoxin $A_{4}$, an endogenous $C B 1$ positive allosteric modulator, was shown to have protective properties against $\beta$-amyloid-induced spacial memory impairment in mice [173]. Due to its presence in microglia, CB2 may also be a promising target [174]. Interestingly, CB2 forms heterodimers with GPR18, which exhibit considerable interactions, thus GPR18 may be a promising target, although more research is needed [175]. Moreover, $\beta$-amyloid promotes MAGL overexpression. Therefore, increasing 2-AG concentration via MAGL inhibition has therapeutic potential in AD. Indeed, MAGL inhibitor forsythiaside in vitro decreased neuroinflammation via CB1-dependent nuclear factor- $\kappa$ B (NF- $\kappa$ B) pathway [176]. TRPV1 agonist, capsaicin, reduced $\beta$-amyloid-induced degradation of hippocampal neuron functions in vitro [177].

As ECS modulates nigrostriatal pathway and dopaminergic transmission, it may find its place in Parkinson disease therapy. Targeting CB1 and GPR55 was proposed [178]. In addition, FAAH inhibitor, URB597 (0.2 $\mathrm{mg} / \mathrm{kg}$ every 3 days for 30 days), was shown to decrease dopaminergic neuronal death and improve motor functions in the rodent exitoxicity model [179].

In addition, CB1 is downregulated in Huntington's [180,181]. GAT229 (10 mg/kg/day), a CB1 PAM, positively affected motor functions and gene expression, as well as delayed the onset of symptoms in the mice model of Huntington's disease [182]. MAGL inhibitor, JZL-184 (18 mg/kg, intraperitoneally), was shown to restore dopaminergic signaling in CB1-dependent way, and thus normalize behavior in mouse model [183]. ECS targeting is also proposed in treatment of spinocerebellar ataxias (SCAs), although there is some contrary evidence. CB1 agonism is believed to prevent neurotoxicity [184]. On the other hand, some older studies indicate that enhancing CB1-dependent signaling may affect in ataxic symptoms $[185,186]$. CB2 activation is proposed for neuroprotection [187].

FAAH inhibitor, PF3845, attenuated development of human immunodeficiency virus 1 (HIV-1) associated neurocognitive disorders (HAND) in CB1- and CB2-dependent manner in vitro. CB1 activation was proved to decrease intracellular Ca levels, thus decreasing neurotoxic glutaminergic activity. CB2 activation was responsible for reduction of neuronal death and degradation [188].

While CB1 agonism is usually the proper direction in fighting neurodegenerative diseases, there are exceptions-for example, in focal cortical dysplasia (FCD), where upregulation of CB1 leads to increased mTORC1 (mammalian target of rapamycin complex 1) signaling, and thus to malformations in cortical development. Rimonabant was proved to decrease mTORC1 overactivation in vitro [189].

\section{Inflammatory and Autoimmune Diseases}

CB2 is distributed mainly in cells of the immune system [9]. Therefore, it is natural that this receptor has been viewed as a potential target for the treatment of inflammatory and autoimmune 
diseases. There are numerous studies proving that CB2 activation leads to anti-inflammatory action. In various mammalian models, CB2 agonists inhibit recruitment of leukocytes, and decrease levels of TNF- $\alpha$ and interleukin $1 \beta$ (IL-1 $\beta$ ) [190], IL-6, IL-18, monocyte chemoattractant protein 1 (MCP-1) [191], and reactive oxygen species (ROS) [192]. Additionally, CB2 agonism results in 5' AMP-activated protein kinase (AMPK) activation and subsequent reduction in anabolic processes and promotion of oxidative phosphorylation (OXPKOS), and thus anti-inflammatory effect [193-195]. CB2 agonists may be employed in the treatment of rheumatoid arthritis, atherosclerosis, inflammatory bowel disease [192], and ocular inflammations [196].

On the other hand, CB2 antagonists may be of use as well. Lipopolysaccharides (LPS, endotoxins) are molecules on the membrane of Gram-negative bacteria. Normally, LPS exposure leads to inflammatory response, among others, in the form of increased TNF secretion. Prolonged exposure to LPS results in toll-like receptor 4 (TLR4) activation, subsequent increase in 2-AG production in mast cells, CB2 activation, and finally hyporesponsivity of mast cells, called endotoxin tolerance (ET). CB2 antagonist, AM630, prevented ET in vitro [197], and thus CB2 antagonists may be studied further as a potential treatment for immunoparalysis.

Apart from CB2, also other components of ECS take part in the regulation of immune processes. Their impact is complex, in part because of interdependence of ECS and the prostanoid system [198]. AEA and PEA usually exhibit anti-inflammatory effects, while 2-AG may act both anti- or pro-inflammatory $[199,200]$. Alongside CB2, CB1 also contributes to the homeostasis of the immune system. Unfortunately, its functions are not straightforward. Increased expression of CB1 was shown to promote oxidative stress and inflammation [201]. Contrarily, CB1 agonists decreased mast cell activation in vitro, exhibiting also anti-inflammatory activity in the rodent model, and are proposed as anti-inflammatory agents in psoriasis and dermatitis [202]. Moreover, as we showed above, CB1 agonists exhibit anti-neuroinflammatory properties. In addition, the MAGL inhibitor JZL184 $(4 \mathrm{mg} / \mathrm{kg})$ reduced TNF- $\alpha$ levels in a CB1-dependent manner in mice [203]. FAAH inhibitors proved to be anti-inflammatory agents in vitro and in rodent models. In detail, they reduce PGE2 production, downregulate COX-2, reduce expression of pro-inflammatory cytokines, reduce inducible nitric oxide synthase (iNOS) activity, and alleviate TLR3 mediated fever $[168,204,205]$. The role of TRPV1 remains unclear. Some studies suggest that TRPV1 activation leads to the release of pro-inflammatory cytokines in asthma, and TRPV1 antagonists could be used in the treatment of this disease [206]. Other publications show that TRPV1 agonists reduce TNF- $\alpha$ production in rodent models and may be employed in inflammatory diseases [207]. Additionally, GPR55 seems to be a promising target. AEA was shown to inhibit mast cells degranulation in vitro via CB2 and GPR55 activation, and CB2-GPR55 heterodimers were probably involved [208]. On the other hand, GPR55 antagonists exhibited anti-neuroinflammatory action in vitro [170].

ECS proteins may also be used in the treatment of autoimmune diseases. Dual CB2/PPAR $\gamma$ agonists, JBT-101 (5 mg/kg), and EHP-101 (a lipidic formulation of VCE-004.8) (20 mg/kg) alleviated skin fibrosis in rodent models of systemic sclerosis (SSc). Moreover, JBT-101 (ajulemic acid, Lenabasum) (5-20 mg) was shown to exert anti-inflammatory action in a human skin inflammation study [209,210]. JBT-101 reached phase III or II clinical trials for several indications (see: Section 11. Approved drugs and clinical trials). In addition, CB2/PPAR $\gamma$ agonist with CB1 antagonistic property, VCE-004.3, was proposed for the treatment of SSc, based on promising in vitro results [211]. Dual CB1/iNOS inhibitor, MRI-1867 (10 mg/kg), exhibited antifibrotic activity in the rodent model of pulmonary fibrosis [212]. Alteration in ECS proteins expression was shown in psoriasis, with an increase in CB1 in psoriatic arthritis, CB2 in psoriasis vulgaris, and GPR55 in both forms of the disease. In addition, elevated levels of 2-AG and AEA were observed [201]. Therefore, ECS seems to be a reasonable target in psoriasis, although more research is needed. Surprisingly, CB2 activation was found to play a pathogenic role in renal fibrosis. XL-001 (20 mg/ $\mathrm{kg}$ intraperitoneally), a CB2 inverse agonist designed using in silico methods, reduced inflammation and ameliorated kidney fibrosis in the rodent model [213]. 


\section{Metabolic Diseases}

One of the main functions of ECS is the control of energy homeostasis. Endocannabinoid signaling favors energy intake and storage, as well as affects metabolism and thus it can contribute to the development of obesity and metabolic syndrome [214].

\subsection{Obesity}

Cannabinoids are known to increase appetite, even in a satiated state, and the consumption of highly palatable food [77]. This orexigenic effect is mediated via CB1 activation in forebrain glutamatergic neurons, hypothalamus, and in a mesolimbic dopamine system [215]. Thus, a pharmacological modulation of CB1 may be used to control food intake [216].

In spite of CNS-supervised mechanisms, ECS also participates in the peripheral control of energy metabolism. First of all, CBRs regulate the conversion of white adipose tissue (WAT) into thermogenic, positively influencing energy balance beige adipose tissue in process called browning. This transformation is enhanced either by CB1 inhibition or CB2 activation [214]. Moreover, the CB1 activation promotes adipogenesis, liver lipogenesis, and may exert a pro-inflammatory effect [215] while CB2 mediates inhibition of obese-related inflammation and thus decreases the risk of adverse outcomes in obesity [214].

Considering this, CB1 antagonists or inverse agonists as well as CB2 agonists seem to be a useful tool in the treatment of obesity and related symptoms. Indeed, rimonabant $(20 \mathrm{mg} /$ day $)$ proved to be efficient in reducing body weight and in improving cardiovascular and metabolic risk factors in phase III clinical trial [217]. However, its severe psychiatric adverse effects suggest that the central CB1 inverse agonism is not the right direction. Peripheral antagonism of CB1 and thus avoiding central effects appears to be a reasonable option. Recently, significant research has been conducted on peripherally restricted CB1 antagonists or inverse agonists [218]. For instance, AJ5012 (10-20 mg/ kg/day), a peripheral CB1 antagonist, was reported to cause a significant weight loss, increase energy expenditure, ameliorate glycemic control and insulin sensitivity, and to reduce inflammation in rodent model [219]. Similarly, AJ5018 (10 mg/ $\mathrm{kg} /$ day) was shown to improve metabolic abnormalities and suppress adipose tissue inflammation via moderation of macrophage infiltration, activation of the NLRP3 inflammasome, and reducing production of pro-inflammatory cytokines in mice [220]. Neither compound elicits neurobehavioral adverse effects due to low brain penetrance. Other possible strategy is the employment of CB1 neutral antagonists instead of inverse agonists. Such compounds (e.g., PIMSR $-10 \mathrm{mg} / \mathrm{kg} /$ day) were shown to effectively reduce body weight and adiposity in mice and may be safer in terms of psychiatric adverse effects [221]. Moreover, CB1 NAMs have been proposed as well. PSNCBAM-1 (30 mg/ kg intraperitoneally) significantly reduced food intake and decreased body weight in a rodent model [222]. Administration of ORG27569 (5.6-10 mg/ kg/day) also led to hypophagic effect in mice [223]. However, more research is needed, as it was shown that ORG27569 in some cases may act in a CB1-independent manner [62,132].

In addition, GPR55 participates in the regulation of energy metabolism. Its deficiency was found to significantly decrease insulin signaling in adipose tissue, liver, and skeletal muscle, reduce physical activity, and enhance adiposity via increased lipogenic proteins expression in adipose tissue in rodents [224]. Recently, dual GPR55 and GPR18 agonists, such as O-1602 (5 mg/kg/day) and O-1918 $(1 \mathrm{mg} / \mathrm{kg} /$ day), were shown to improve albuminuria and decrease body weight and body fat in rats, unfortunately, also causing changes in liver and kidney morphology and increased inflammation [225].

\subsection{Diabetes}

Apart from the ECS role in obesity, ECS deregulation contributes to occurrence and progression of type 2 diabetes mellitus (T2DM) [226,227]. Considering CB1 participation, its activation was shown to decrease insulin signaling, reduce proliferation and viability of pancreatic $\beta$-cells, and to promote pancreatic inflammation [228,229]. CB1 antagonists (e.g., JD5037-3 mg/kg) were shown to reverse 
diabetic neuropathy (DN) in mice via modulation of glucose transporter 2 (GLUT-2) expression and activity in renal proximal tubule cells $[230,231]$. Furthermore, AM6545 $(10 \mathrm{mg} / \mathrm{kg} /$ day $)$, a peripheral CB1 antagonist, combined with angiotensin-converting enzyme (ACE) inhibitor, was shown to reverse albuminuria, nephrin loss, and to inhibit inflammation in rodent model of DN [232]. In addition, suppressing CB1 expression by microRNA-29a decreased pro-inflammatory and pro-fibrogenic mediators' levels as well as mitigated renal hypertrophy in mice [233].

On the contrary, CB2 generally exerts the opposite effect on diabetes and DN. The CB2 activation enhances insulin release, decreases pro-inflammatory cytokines' levels, and attenuates oxidative stress [234]. In addition, activation of CB2 by HU308 ( $3 \mathrm{mg} / \mathrm{kg} /$ day) exerted a cardioprotective effect in diabetic cardiomyopathy in mice [235].

Other GPCR, GPR55 elicits a beneficial impact on T2DM due to increasing insulin secretion, improving glucose tolerance, and a positive effect on $\beta$-cells' viability [229]. For instance, GPR55 agonists, such as O-1602, were demonstrated to reduce endoplasmic reticulum (ER) stress-induced apoptosis in pancreatic $\beta$-cells in vitro [236].

It is interesting that GPR119 enhances both insulin and glucagon-like peptide-1 secretion $[237,238]$. A significant number of GPR119 agonists took part in clinical trials, from which the majority was discontinued [239]. However, multi-target drugs may be a promising strategy, as a dual GPR119 agonist and dipeptidyl peptidase 4 (DPP4) inhibitor, HBK001 (30 mg/ $\mathrm{kg})$, was demonstrated to meaningfully improve glucose homeostasis and $\beta$-cell function in the rodent model [240].

\subsection{Hepatic Diseases}

ECS partially controls hepatic glucose and lipid metabolism as well as influences fibrogenesis and inflammation. Thus, ECS members, especially CB1 and GPR119, are promising targets in the treatment of liver diseases [241]. While CB1 promotes fibrogenesis, activation of CB2 results in antifibrogenic responses [241]. CB1 inhibition with rimonabant $(10 \mathrm{mg} / \mathrm{kg} /$ day $)$ in the mice model of nonalcoholic fatty liver disease (NAFLD) improved adipokine profile, decreased glucose plasma concentration, and reduced inflammation in adipose tissues and liver [242] and in the rat model of nonalcoholic steatohepatitis (NASH) inhibited hepatic fat infiltration, inflammation, fibrogenesis, and cellular death [243]. In addition, APD668 (30 mg/kg), a GPR119 agonist, was shown to reduce circulating cholesterol, glucose, triglyceride, and hepatic injury markers in rodent NASH model [244]. Therefore, GPR119 agonists may be useful for the treatment of dyslipidemia and NASH.

\section{Cardiovascular Diseases}

According to the latest systematic review, Cannabis use may result in cardiovascular adverse effects, including ischemic stroke [245]. Nonetheless, plenty of studies reported that the modulation of ECS results in the alleviation of hypertension, atherosclerosis, myocardial ischemia, and related diseases [246].

\subsection{Hypertension}

The ECS control of blood pressure (BP) involves various neuronal and non-neuronal mechanisms. Based on various human and animal studies, $\mathrm{CB} 1$ is suggested to play a major role in these actions and while central activation of CB1 increases BP, peripheral activation tends to lower BP [246,247]. However, the activation of either or both CBRs was demonstrated to increase contractility in vascular smooth muscles in vitro [248].

Cannabinoids, acting peripherally, are generally known to decrease BP. However, the final outcome depends on the type of a cannabinoid ligand, model of hypertension as well as age and sex [247]. For instance, AEA (5 mg/ $\mathrm{kg} /$ week) decreased BP and reversed all altered cardiovascular markers and parameters in hypertensive rats [249].

Lately, FAAH inhibitors are investigated as antihypertensive drugs. PF-3845 (0.45-0.9 $\mu \mathrm{M} / \mathrm{kg})$, a selective FAAH inhibitor, reduced mean arterial pressure and increased diuresis in mice [250]. 
Another FAAH inhibitor, URB597 (1 mg/kg twice a day), lowered BP and heart rate in older but not in younger rats [251]. However, special caution must be taken in drugs targeting FAAH, as URB597 ( $1 \mathrm{mg} / \mathrm{kg}$ twice a day) was reported to disturb the kidney redox system as well as phospholipid ROS-dependent and enzymatic-dependent metabolism in the rodent model [252].

In addition, using TRPV1 agonists may be an interesting way to modulate BP centrally as TRPV1 in ventral medial prefrontal cortex was reported to facilitate the cardiac baroreflex response in rats through stimulating the NMDA activation and NO synthesis. [253]. However, based on in vitro study, TRPV1 activation may aggravate idiopathic pulmonary arterial hypertension (IPAH) [254].

\subsection{Atherosclerosis}

As ECS is known to regulate inflammatory and metabolic processes, its modulation seems to be useful in atherosclerosis. ECS components are suggested to modulate vascular inflammation, leukocyte migration, macrophage cholesterol metabolism, and plaque stability [255].

CB1 activation generally exerts a deleterious effect in atherosclerosis. CB1 agonists such as AEA or HU-210 promoted endothelial dysfunction via ROS generation and promotion of apoptosis in vitro [256]. Moreover, rimonabant $(8 \mathrm{mg} / \mathrm{kg} /$ day $)$ decreased atherosclerotic lesions in the aorta and increased serum adiponectin levels in mice [257]. On the contrary, CB2 activation exerts atheroprotective actions due to its anti-inflammatory and anti-proliferative properties [255], and this may be achieved via MAGL inhibition. MAGL genetic deficiency or inhibition with JZL184 (16 mg/kg 3 times a week) were shown to limit plaque formation in mice. Furthermore, the CB2 activation by 2-AG mediated atheroprotective B1a lymphocyte phenotype [258].

GPR55 agonism might be an interesting strategy to modulate arterial inflammation [255]. For instance, PEA ( $3 \mathrm{mg} / \mathrm{kg} /$ day), acting via GPR55 and PPAR $\alpha$ in early atherosclerosis stabilized plaque in pre-established phase of the disease in mice. GPR55 activation promoted anti-inflammatory and pro-resolving macrophage subtype [259]. In addition, GPR55 role in regulating neutrophil degranulation in atherosclerosis was demonstrated in rodent model by the use of GPR55 antagonist CID16020046 (0.5 mg/kg 5 times a week) [260].

\subsection{Myocardial Dysfunctions}

The data on cardioprotective impact of endocannabinoids are conflicting and are based mainly on studies on rodents. Some studies suggest 2-AG deleterious impact in myocardial infraction (MI) via CB2 activation and myeloid cells recruitment, as shown by the MAGL inhibitor, JZL184 $(16 \mathrm{mg} / \mathrm{kg})$ in mice [261]. According to another study on rodents, the CB2 activation promotes myocardial adaptation to pressure overload and remodeling via apoptosis prevention, inflammation and oxidative stress reduction, and regulation of contractile elements' expression in cardiomyocytes [262]. Furthermore, according to several in vivo studies, activation of CB2 and TRPV1 modulates myocardial damage during myocardial ischemia [246].

MAGL inhibition gives promising results in the case of cardiac arrest. Administration of single dose of URB602 $(5 \mathrm{mg} / \mathrm{kg})$, a MAGL inhibitor, turned out to significantly improve survival rate and reduce myocardial injury in the rodent model [263].

\section{Cancer}

Although, to date, the use of cannabinoids in cancer is limited to alleviating symptoms like nausea or pain, a plethora of studies revealed both their antitumor and protumorigenic properties. As most components of ECS are overexpressed in tumor cells, its modulation appears to be a promising approach, as shown in Figure 3. 


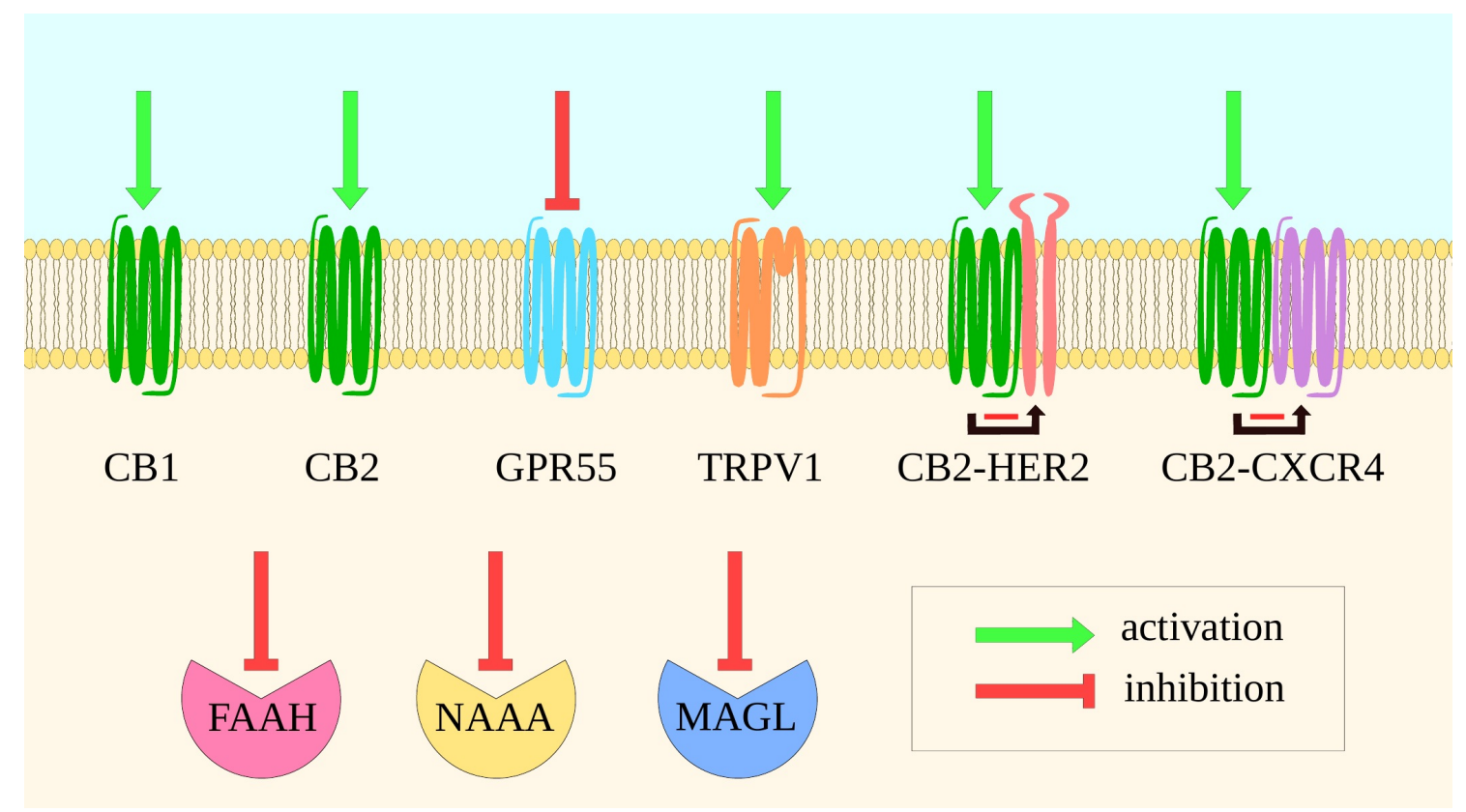

Figure 3. A schematic presentation of ECS components targeted in cancer. The figure shows typical and new directions of ECS modulation in neoplasm diseases. Well-investigated directions include the activation of CBRs or TRPV1, suppression of GPR55 signaling as well as the inhibition of FAAH and MAGL. Promising targets may be another cannabinoid degrading enzyme, NAAA [264] as well as CB2 heteromers, such as CB2-HER2 and CB2-CXCR4, as activation of CB2 inhibits HER2 and CXCR4 signaling, respectively $[265,266]$. Green arrows indicate protein activation, red arrows-inhibition. Black arrows with red lines show HER2 or CXCR4 inhibition by CB2 activation in respective heterodimers.

Multiple $\mathrm{CB} 1$ and $\mathrm{CB} 2$ agonists were shown to elicit antitumor properties both in vitro and in vivo (for a review, see: [267]). For instance, CB2 agonist, LV50 elicited cytotoxic effect in lymphoblastoid cells with high specificity to neoplasm cells [268], and WIN 55,212-2, CB1/2 agonist was able to arrest cell cycle and cause apoptosis in renal carcinoma in vitro [269]. In addition, allosteric CB1 modulators inhibiting cell proliferation in vitro [270] are a promising approach. Such compounds may allow for avoiding CB1 activation-related adverse effects. However, there is a report on tumor-progressive roles of CB1 agonist in melanoma cells [271].

CB2 may exist in heteromers in various cancer subtypes. CB2 forms heteromers with human epidermal growth factor receptor 2 (HER2) in HER2+ breast cancer cells. CB2 regulates HER2 signaling, leading to a prooncogenic effect. However, the $\mathrm{CB} 2$ activation with an exogenous agonist disrupts the HER2 protumoral action in vitro [266]. CB2 can be found in connection with C-X-C chemokine receptor type 4 (CXCR4) in breast and prostate cancer cells. In vitro, CB2 activation was shown to reduce CXCR4-mediated cancer functions such as chemotaxis [265].

Concerning eCBs, they generally exert tumor-suppressive effect, based on clinical observations [272]. In vitro, AEA was demonstrated to decrease invasion and metastasis by upregulating a tissue inhibitor of matrix metalloproteinases-1 (TIMP-1) [273] and to induce apoptosis via oxidative stress in COX-2- [274] and TRPV1-dependent manner [275]. 2-AG (20 mg/kg/day) showed similar properties in the rodent model, at the same time suppressing tumor immune-mediated surveillance [276]. Therefore, inhibition of degrading enzymes and thus upregulation of eCBs' levels seems to be a valid strategy.

High levels of MAGL were shown to be associated with tumor malignancy, based on clinical observations and in vivo studies [277-279]. Concerning pathomechanism of MAGL, formation of protumorigenic lipid signals rather than lowering eCBs' levels causes procancerogenic effects [280]. Recent research is focused on highly selective reversible MAGL inhibitors with anticancer 
properties [281]. For instance, JZL184 was reported to reduce cancer cells growth, induce apoptosis, and prevent invasion in vitro $[279,282]$ as well as suppress osteolytic bone metastasis and alleviate cachexia and bone mass loss in rodents (8-16 mg/ $\mathrm{kg}$ ) [283]. Another MAGL inhibitor, URB602 $(5 \mathrm{mg} / \mathrm{kg})$, suppressed progression of colon cancer in mice [284].

FAAH inhibitors were also proved to exert antiproliferative and proapoptotic action in multiple in vitro studies, especially in combination with ethanolamines [285]. Furthermore, there appeared a proposition of development of dual FAAH inhibitors and PPAR agonists as a multi-target approach in anticancer therapy [286]. In addition, 1,2-dihydro-2-oxo-pyridine-3-carboxamides, influencing at least two components of ECS, showed cytotoxic activity in lymphoblastoid cells [287].

$\mathrm{N}$-acylethanolamine acid amidase (NAAA), another eCB degrading enzyme, was reported as a promising tool in cancer therapy, as NAAA inhibitors reduced bladder cancer cells proliferation and inhibited migration in vitro [264].

TRPV1 is extensively investigated in neoplasms. Its stimulation with AEA or CBD led to apoptosis and inhibited proliferation of different types of tumor cells $[275,285]$.

GPR55 appears to be a promising target as well. Its activation with lysophosphatidylinositol (LPI) was demonstrated to elicit a tumor promoting effect in colon (in vitro) [288], colorectal (in vitro and in vivo) [289], and breast carcinoma (in vitro and in vivo) [290,291]. In this spotlight, LPI-GPR55 axis inhibitors may be an effective strategy to suppress cancer progression. Moreover, a GPR55 peptide ligand was shown to suppress the proliferation of B-lymphoblastoid cell lines [292].

In addition, combining cannabinoids with other anticancer therapies brings enhanced results [293]. For example, in the case of triple negative breast cancer, the combination of photodynamic therapy with CB2 agonist (JWH-133) $(40 \mathrm{nmol})$ resulted in synergistic inhibition of tumor growth and extended survival time in mice [294].

\section{Other}

\subsection{Respiratory Disorders}

The data on the role of ECS in asthma are ambiguous. On the one hand, the Cannabis use is known to elicit deleterious effects on the respiratory tract and to exacerbate asthma symptoms [295]. On the other hand, targeting CBRs may be effective in asthma treatment due to bronchodilatory action. This effect is caused by CB1 activation and subsequent inhibition of release of acetylcholine and other mediators from parasympathetic terminals in bronchi [296]. In addition, the CB1 activation by ACEA $(7.5 \mathrm{mg} / \mathrm{kg} /$ day $)$ prevents 5 -HT-induced tracheal hyperactivity in mice [297]. Furthermore, CBD $(5-10 \mathrm{mg} / \mathrm{kg}$ ) was recently reported to decrease the inflammatory and remodelling processes in a murine model of allergic asthma probably via CB1/CB2 signaling and in receptor-independent manner [298].

CBRs are also involved in pulmonary fibrosis. Studies showed that CB1 exerts proinflammatory and profibrotic effect in pulmonary fibrosis $[299,300]$ and peripherally restricted dual inhibitor of CB1 and iNOS, MRI-1867 (10 mg/kg/day), partially attenuated fibrosis in rodent models [301]. Concerning CB2, its agonist, JWH $133(1 \mathrm{mg} / \mathrm{kg})$, attenuated nicotine-induced fibrosis while AM630 (0.5 mg/ $\mathrm{kg})$, a CB2 antagonist, enhanced it in mice [302].

\subsection{Gastroenterology}

ECS controls gastrointestinal (GI) tract (GIT) motility, sensitivity, and inflammatory processes, and thus appears to be an interesting target in the treatment of GI diseases, with a significant role in inflammatory bowel disease (IBD) [303]. Although the data on ECS tone in IBD is not consistent, the eCBs level is generally increased, from which LPI, an endogenous GPR55 agonist, may exert a pro-inflammatory effect, based on clinical observations [304]. A number of CB1 and CB2 agonists were proven to be effective in ameliorating IBD symptoms in animal models. However, clinical studies on THC and CBD in IBD treatment in most cases failed to meet the primary endpoint, 
but an improvement was observed [305]. According to recent research, AM9405 (0.1-1 mg/kg), a peripheral CB1 and 5-HT3 agonist, suppressed hypermotility of the GI tract and reduced pain in the rodent model [306]. In terms of other GI disorders, a retrospective human study showed that nabilone (1-10 mg/kg), a CB1 agonist, efficiently reduced diarrhea and induced weight gain showing a reasonable safety profile [307]. In another study, a CB1 positive allosteric modulator, ZCZ011 (10-40 mg/kg), combined with an ineffective dose of MAGL inhibitor JZL184 $(1 \mathrm{mg} / \mathrm{kg}$ intraperitoneally), exhibited antiulcerogenic properties in a rodent model [135]. In addition, inhibition of eCBs degrading enzymes is a promising approach, as numerous FAAH inhibitors and one MAGL inhibitor were shown to reduce IBD symptoms in animal models [305].

Endocannabinoid signaling is also known for its anti-emetic properties. This is associated mostly with an activation of both central CB1 and peripheral CB1 in GIT. Thus, CB1 agonists may act as anti-emetic agents. On the other hand, CB1 inverse agonists exert emetogenic properties, as shown by the example of rimonabant in clinical trials [308]. Cannabinoids are also potent solutions for chemotherapy-induced nausea that is unresponsive to traditional drugs (see: Section 11. Approved drugs and clinical trials) [309]. Moreover, CB2 and TRPV1 agonists are also proposed as anti-emetic drugs, based on results of animal studies. [308,310].

\subsection{Osteology}

ECS is involved in osteoclast/osteoblast activity with the emphasis on CBRs and TRPV1 function. CB1 activation generally inhibits osteogenic signaling [44]. In addition, the downregulation of CB1 expression in hypothalamus by central adiponectin in the epigenetic mechanism was reported to promote peripheral bone formation in mice [311]. Importantly, the action of CB1 antagonists is age-dependent: rimonabant $(0.2 \mathrm{mg} / \mathrm{kg})$ prevented osteoporosis in young rats but aggravated it in older ones [312].

On the contrary, CB2 activation promotes bone matrix deposition. For instance, CB2 agonists, HU-308, and its more potent enantiomer HU-433 were shown to stimulate osteoblast proliferation and osteoclast differentiation in vitro [313].

TRPV1 activation leads to osteoclasts differentiation in the RANKL-mediated pathway. TRPV1 antagonist, SC0030, inhibited this process in vitro [314]. Considering this, dual CB2 agonists and TRPV1 antagonists are proposed as a promising tool in bone mass loss treatment [44].

\subsection{Reproductive System}

Concerning female reproductive system, ECS affects the hypothalamic-pituitary-ovarian (HPO) axis, steroid hormones production, and secretion, as well as controlling ovaries and uterus functioning. Changes in ECS in female reproductive tissues may cause pathological states [315]. For example, based on clinical observations, increased AEA plasma level and decreased FAAH endometrium level are probably involved in pathogenesis of polycystic ovarian syndrome [316]. CBRs may also be associated with adenomyosis, as their expression is significantly lowered independent on cycle phase in endometrium of adenomyosis bearing patients [317]. CB1 agonists are investigated as a possible treatment for endometriosis with contradictory results. While WIN 55,212-2 limited cell proliferation in vitro, methanandamide $(5 \mathrm{mg} / \mathrm{kg})$ contributed to development of ectopic lesions in mice [318]. However, modulation of ECS in gynecological disorders has lot of limitations. ECS is activated with spatial and temporal specificity, plasma, and local levels of ECS components often differ and mechanisms underlying ECS regulation of female reproductive system and the crosstalk with HPO axis are not fully revealed [315].

When it comes to male reproductive system, CB1 is present in nerves in corpus cavernosum [319] and is responsible for Cannabis-related erectile dysfunction [320]. While designing CB1 agonists, one may expect possible sexual adverse effects. On the other hand, CB1 antagonists were proposed for the treatment of erectile dysfunction, e.g., SR $141716 \mathrm{~A}(1 \mathrm{mg} / \mathrm{kg}$ twice a day), interestingly exhibiting action via central CB1 in hypothalamus, based on a study on rodents [321]. Due to the localization of 
CB1 population important in this context, the CB1 peripheral antagonists or inverse agonists may be a valid strategy as well.

\subsection{Dermatology}

Members of ECS regulate key aspects of skin homeostasis, including immune modulation, inflammation, cell proliferation, and differentiation as well as regulation of sebaceous glands, hair growth, pigmentation, and wound healing and thus its dysregulation contributes to various cutaneous diseases (for a review, see: [322,323]). According to a recent study, inhibition of eCB reuptake in human sebocytes with VDM11 exerts an anti-inflammatory effect as well as elevates sebaceous lipid production and eCB levels. This may be beneficial in treatment of skin conditions accompanied with inflammation and dryness [324].

\subsection{Genetic Disorders}

Targeting CB1 may be an interesting approach to treat genetic disorders like Duchenne muscular dystrophy. CB1 expression is upregulated on the onset of this disease. As CB1 signaling inhibition by rimonabant resulted in the promotion of human satellite cell differentiation in vitro, increase of muscle regeneration, and improvement of locomotor activity in dystrophic mice $(0.5 \mathrm{mg} / \mathrm{kg} 3$ times a week), CB1 antagonism appears to be useful in treatment of muscular dystrophies [325]. It is interesting that CBD and cannabidivarin (CBDV) elicit similar effects [326].

\section{Approved Drugs and Clinical Trials}

We described a plethora of possible therapeutic areas, in which ECS proteins may potentially be targeted. The advancement of the aforementioned research varies. Many of these proposals are supported by limited evidence. While it may be worth exploring some of them more deeply, and potentially to employ such ideas in the future drug design, many of these directions will probably turn out to be a blind alley. However, there are also drugs and drug candidates with solid information about their action and safety verified by clinical trials (Table 2).

Several drugs reached the market. These include mainly THC, CBD, and their analogs or combinations. Drugs containing dronabinol $(\triangle 9-\mathrm{THC})$ were approved by the Food and Drug Administration (FDA) for 1) nausea and vomiting associated with cancer chemotherapy in patients who have failed to respond adequately to conventional antiemetic treatments, and for 2) anorexia associated with weight loss in patients with acquired immunodeficiency syndrome (AIDS) [309,327-329]. Cesamet, a drug containing THC analog-nabilone, also was approved for the first aforementioned indication [330,331]. Alas, administration of THC and its derivatives alone comes with risks of adverse effects, as such drugs have a narrow therapeutic window [332]. However, combination of THC, a CB1/2 partial agonist, with CBD was shown to attenuate THC-derived psychiatric adverse effects [333], which is also important in the case of the proportions of these compounds in Cannabis [334]. Combinations of THC and CBD are approved in multiple countries for the treatment of spasticity and pain in multiple sclerosis or cancer pain [335,336]. In addition, CBD alone has its place in medicine. Epidiolex, an oral solution containing CBD, was approved by FDA in two forms of epilepsy: Lennox-Gastaut syndrome and Dravet syndrome [100]. CBD has a complex mechanism of action, including CB1 negative allosteric modulation, TRPV1 agonism, GPR55 antagonism, and 5-HT1A agonism, and interacts with multiple other pharmacologically relevant receptors and channels [40,101-103]. Other examples of drugs that reached the market include Acomplia or Zimulti, containing rimonabant, a CB1 inverse agonist, as an active ingredient. They were approved in Europe for the treatment of obesity but were withdrawn due to major phychatric adverse effects [10]. These examples show that drugs or combinations of drugs targeting various ECS proteins may exhibit more desirable therapeutic profiles than compounds acting on a single molecular target. Such strategy might be valid in the context of not disrupting the homeostasis of ECS. However, the combination of THC and CBD is the most extensively studied example of this direction. In order to work on other potential ECS-related multi-target drugs, the ECS 
itself has to be better understood, which includes exploring multiple effects of the endocannabinoid signaling modulation. Moreover, CB1 activation or inhibition has to be planned with caution, as aside from desired effects, it may also lead to adverse ones, especially due to the impact on central CB1.

Because of a great potential of targeting ECS, new potential drugs are constantly developed. Some of them are being tested in clinical trials. Among them, CB2 agonists reached the most advanced phases. Because this receptor is distributed mainly in the immune cells [9], CB2 agonists were naturally investigated as a potential treatment for autoimmune and inflammatory conditions. JBT-101 (Lenabasum) is currently in phase III trials for diffuse cutaneous systemic sclerosis and for dermatomyositis, and in phase II trials for cystic fibrosis, systemic sclerosis, and systemic lupus erythematosus [337,338]. APD371 (Olorinab) reached phase II trials for abdominal pain in Crohn's disease and for irritable bowel syndrome [339].

As targeting CB1 comes with risks of central adverse effects, some prospective drugs were designed to overcome this issue by acting only on peripheral CB1. NEO1940 (ART27.13) is a peripheral CB1 and CB2 agonist with a phase II trial planned for cancer related anorexia. Phase I trials showed desired weight gain [340]. CRB-4001, a peripheral CB1 inverse agonist is waiting for phase I trial as a potential drug for nonalcoholic steatohepatitis [341,342].

Other proteins of ECS are targeted by compounds that reached clinical trials as well. In the area of eCB degrading enzymes, ABX-1431, a MAGL inhibitor is the most promising drug candidate. It reached a phase II trial for the treatment of Tourette's syndrome and chronic motor tic disorder [343].

Several FAAH inhibitors were tested in clinical trials as prospects for new analgesic drugs. A few examples include PF-04457845 [344], JNJ-42165279 [345], and BIA 10-2474 [346]. Unfortunately, all of them reached at most phase II. They proved to be either not effective or led to neurological disorders. Causes of the undesirable therapeutic profile of FAAH inhibitors remain not entirely clear. The proposed explanations suggest the pro-nociceptive activity due to the activation of presynaptic TRPV1 by AEA, and AEA being metabolized to pro-inflammatory prostaglandins by COX. As the up-to-date failures show, FAAH inhibition seems to be a risky direction in drug design. Possible solutions to overcome the obstacles, and to utilize FAAH-targeting compounds in medicine include dual FAAH/TRPV1 and FAAH/COX-2 inhibitors, although these proposals require more evidence [84].

NEO6860, a TRPV1 antagonist, was tested for osteoarthritis pain in a phase II trial. Thus far, it did not exhibit desired effects in comparison to placebo [347]. However, phase I trials showed analgesic activity. Moreover, NEO6860 administration did not lead to hyperthermia, which is a major problem in the case of TRPV1 antagonists $[159,348]$. Thus, further studies on this compound may be potentially rewarding. 
Table 2. Approved drugs and compounds in clinical trials.

\begin{tabular}{|c|c|c|c|c|c|}
\hline $\begin{array}{c}\text { Name of the } \\
\text { Active Ingredient }\end{array}$ & Mechanism of Action & Indications & Status & Remarks & $\begin{array}{c}\text { References } \\
\text { Clinical Trial IDs }\end{array}$ \\
\hline $\begin{array}{l}\text { Dronabinol } \\
(\mathrm{THC})\end{array}$ & CB1 and CB2 partial agonist & $\begin{array}{l}\text { Nausea and emesis associated with cancer chemotherapy } \\
\text { Anorexia associated with weight loss in AIDS }\end{array}$ & FDA approved & Problems with therapeutic window & {$[309,327-329]$} \\
\hline Nabilone & CB1 and CB2 partial agonist & Nausea and emesis associated with cancer chemotherapy & FDA approved & Problems with therapeutic window & {$[330,331]$} \\
\hline CBD & $\begin{array}{l}\text { CB1 negative allosteric modulator, } \\
\text { TRPV1 agonist, GPR55 antagonist, } \\
\text { 5-HT1A agonist, interacts with } \\
\text { multiple other proteins }\end{array}$ & $\begin{array}{l}\text { Lennox-Gastaut syndrome and Dravet syndrome } \\
\text { (forms of epilepsy) }\end{array}$ & FDA approved & & {$[40,100-103]$} \\
\hline $\mathrm{THC}+\mathrm{CBD}$ & See: dronabinol and CBD & $\begin{array}{l}\text { Spasticity and pain in multiple sclerosis } \\
\text { Cancer pain }\end{array}$ & $\begin{array}{l}\text { Approved in } \\
\text { multiple countries }\end{array}$ & & {$[335,336]$} \\
\hline Rimonabant & CB1 inverse agonist & Obesity & Withdrawn & $\begin{array}{l}\text { Psychiatric adverse effects } \\
\text { including depression and anxiety; } \\
\text { subsequent suicides }\end{array}$ & [10] \\
\hline \multirow{2}{*}{$\begin{array}{l}\text { JBT-101 } \\
\text { (Lenabasum) }\end{array}$} & \multirow{2}{*}{ CB2 agonist } & $\begin{array}{l}\text { Diffuse cutaneous systemic sclerosis } \\
\text { Dermatomyositis }\end{array}$ & Phase III trials & & \multirow{2}{*}{$\begin{array}{l}{[338]} \\
\text { NCT03398837 } \\
\text { NCT03813160 } \\
{[349,350]} \\
\text { NCT02465450 } \\
\text { NCT02465437 } \\
\text { NCT04043455 }\end{array}$} \\
\hline & & $\begin{array}{l}\text { Cystic fibrosis } \\
\text { Systemic sclerosis } \\
\text { Systemic lupus erythematosus }\end{array}$ & Phase II trials & & \\
\hline $\begin{array}{l}\text { APD371 } \\
\text { (Olorinab) }\end{array}$ & Peripheral CB2 agonist & $\begin{array}{l}\text { Abdominal pain in Crohn's disease } \\
\text { Irritable bowel syndrome }\end{array}$ & Phase II trials & & $\begin{array}{l}{[339]} \\
\text { NCT03155945 } \\
\text { NCT04043455 }\end{array}$ \\
\hline $\begin{array}{l}\text { NEO1940 } \\
\text { (ART27.13) }\end{array}$ & Peripheral CB1 and CB2 agonist & Cancer related anorexia & Phase II trial planned & $\begin{array}{l}\text { Phase I trials showed desired } \\
\text { weight gain }\end{array}$ & [340] \\
\hline CRB-4001 & Peripheral CB1 inverse agonist & Nonalcoholic steatohepatitis & Phase I trials planned & & {$[341,342]$} \\
\hline ABX-1431 & MAGL inhibitor & $\begin{array}{l}\text { Tourette syndrome } \\
\text { Chronic motor tic disorder }\end{array}$ & Phase II trial & & $\begin{array}{l}{[343]} \\
\text { NCT03625453 }\end{array}$ \\
\hline NEO6860 & TRPV1 antagonist & Osteoarthritis pain & Phase II trial & $\begin{array}{l}\text { Phase I trials showed analgesic } \\
\text { activity without hyperthermia; } \\
\text { not effective in phase II trial }\end{array}$ & $\begin{array}{l}{[159,347]} \\
\text { NCT02712957 } \\
\text { NCT02337543 }\end{array}$ \\
\hline
\end{tabular}




\section{Discussion}

ECS is indisputably a complex system. Targeting it has a lot of potential for drug design. Possible diseases and disorders with specific ECS targets that were widely described in this review are concluded in Supplementary Table S1. However, there are some important difficulties, which we will highlight with the example of CB1, and gather in one place the risks that come with targeting this protein with the possible solutions, both of which we discussed in various parts of this review. As CB1 is the main receptor of ECS, a lot of studies were directed to understanding its action, and today it is the ECS protein we have the most comprehensive knowledge of. Firstly, the central activation of CB1 comes with the risk of cognitive impairment [75] and disrupting the ECS regulation of the reward system [76,77]. To avoid these adverse effects, peripheral CB1 agonists, CB1 positive allosteric modulators or indirect activation of CB1 via MAGL or FAAH inhibition are usually proposed. Additionally, the CB1 activation may be associated with weight gain [77], inflammation [201], and erectile dysfunctions [320]. Secondly, the CB1 inverse agonism affects in depression, anxiety [10], and nausea [308]. Possible solutions include: CB1 neutral antagonists, peripheral CB1 neutral antagonists or inverse agonists, and CB1 negative allosteric modulators.

In the case of many disorders, targeting CB2, GPR18, GPR55, GPR119 or TRPV1 instead of CB1 may be a valid strategy as well. However, these proteins are not yet as well understood as CB1. Therefore, targeting them comes with a risk of encountering unknown adverse effects. For example, one has to bear in mind the possible pro-seizure activity of FAAH inhibitors and TRPV1 agonists [93,94], although more research is needed here. This shows that the understanding of each protein of ECS is needed in order to rationally target them. More research is needed here. Nevertheless, we gather the available information regarding potential therapeutic indications for each target, along with adverse effects. These data are summarized in a simplified way for the main proteins in Table 3 and in detail in Supplementary Table S2.

Moreover, it is important to emphasize that ECS, as a complex biological system, does not act alone, but rather in crosstalk and sometimes with important interactions with other systems. The often mentioned here TRPV1 is a protein of endovanilloid system, although, due to its activation by AEA, it may be as well regarded as a member of ECS. Other notable examples of close cooperation include: prostanoid [198], dopaminergic [351], glutaminergic [352], GABAergic [353], serotoninergic [354], opioid [355], and noradrenergic [356] systems. These interactions may be an effect of forming heterodimers of two GPCRs from ECS and other system [351] or crossing metabolic pathways of their endogenous ligands [198]. While targeting ECS presents a great potential, it is important to consider full picture and take into account complex biological factors and understand the physiological environment of this system. Such approach will increase the chances of successfully targeting ECS in drug design. 
Table 3. Potential indications for activation or inhibition of the main proteins of ECS.

\begin{tabular}{|c|c|c|c|c|}
\hline Protein & Ligand Type & Indication & Risks & References \\
\hline \multirow{21}{*}{ CB1 } & \multirow{13}{*}{ Agonist } & Pain & \multirow{13}{*}{$\begin{array}{l}\text { Addiction } \\
\text { Cognitive impairment } \\
\text { Weight gain } \\
\text { Erectile dysfunction }\end{array}$} & {$[78,79]$} \\
\hline & & Seizures & & [91] \\
\hline & & Anxiety & & {$[111,115,118]$} \\
\hline & & Depression & & [121] \\
\hline & & Withdrawal syndrome & & [134] \\
\hline & & Neurodegenerative disorders & & {$[165,172,178]$} \\
\hline & & Spasticity in multiple sclerosis & & [336] \\
\hline & & Hypertension & & {$[246,247]$} \\
\hline & & Cancer & & {$[269,270]$} \\
\hline & & Asthma & & [296] \\
\hline & & Emesis and nausea & & {$[308,309]$} \\
\hline & & Anorexia and weight loss & & [327] \\
\hline & & Duchenne muscular dystrophy & & [325] \\
\hline & \multirow{8}{*}{ Antagonist } & Addiction & \multirow{8}{*}{$\begin{array}{l}\text { Anxiety } \\
\text { Depression } \\
\text { Nausea }\end{array}$} & {$[129,130]$} \\
\hline & & Cognitive impairment & & [146-148] \\
\hline & & Systemic sclerosis & & [211] \\
\hline & & Pulmonary fibrosis & & [212] \\
\hline & & Obesity & & {$[215,216,218,219,221]$} \\
\hline & & Diabetes & & {$[230,231]$} \\
\hline & & Nonalcoholic steatohepatitis & & [243] \\
\hline & & Atherosclerosis & & [257] \\
\hline \multirow{16}{*}{ CB2 } & \multirow{14}{*}{ Agonist } & Pain & & {$[80,81]$} \\
\hline & & Anxiety & & {$[111,118]$} \\
\hline & & Addiction & & {$[141,143]$} \\
\hline & & Neurodegenerative disorders & & [165] \\
\hline & & Inflammation & & {$[192,196,208]$} \\
\hline & & Rheumatoid arthritis & & [192] \\
\hline & & Atherosclerosis & & [255] \\
\hline & & Systemic sclerosis & & {$[210,211]$} \\
\hline & & Obesity & & [77] \\
\hline & & Diabetes & & {$[234,235]$} \\
\hline & & Cancer & & {$[268,269]$} \\
\hline & & Inflammatory bowel disease & & [305] \\
\hline & & Emesis and nausea & & {$[308,310]$} \\
\hline & & Osteoporosis & & [44] \\
\hline & \multirow{2}{*}{ Antagonist } & Immunoparalysis & & [197] \\
\hline & & Renal fibrosis & & [213] \\
\hline \multirow{9}{*}{ MAGL } & \multirow{9}{*}{ Inhibitor } & Pain & & {$[82,84]$} \\
\hline & & Seizures & & [92] \\
\hline & & Tourette syndrome & & [343] \\
\hline & & Anxiety & & [111] \\
\hline & & Depression & & [160] \\
\hline & & Cognitive impairment & & [156] \\
\hline & & Neurodegenerative disorders & & {$[176,183]$} \\
\hline & & Cancer & & {$[279,281-283]$} \\
\hline & & Inflammatory bowel disease & & [305] \\
\hline \multirow{9}{*}{ FAAH } & \multirow{9}{*}{ Inhibitor } & Pain & \multirow{9}{*}{$\begin{array}{l}\text { Seizures } \\
\text { Neurological disorder } \\
\text { Disbalance in the kidney redox system } \\
\text { Disbalance in phospholipid metabolism }\end{array}$} & [83] \\
\hline & & Anxiety & & {$[115,116]$} \\
\hline & & Depression & & {$[121,126]$} \\
\hline & & Cognitive impairment & & [158] \\
\hline & & Neurodegenerative disorders & & [179] \\
\hline & & Inflammation & & {$[168,204,205]$} \\
\hline & & Hypertension & & {$[250,251]$} \\
\hline & & Cancer & & {$[285,286]$} \\
\hline & & Inflammatory bowel disease & & [305] \\
\hline \multirow{8}{*}{ TRPV1 } & \multirow{6}{*}{ Agonist } & Anxiety & & [118] \\
\hline & & Neurodegenerative disorders & & [177] \\
\hline & & Hypertension & Seizures & {$[253,254]$} \\
\hline & & Cancer & Aggravating pulmonary & {$[275,285]$} \\
\hline & & Emesis and nausea & & [310] \\
\hline & & Osteoporosis & & [44] \\
\hline & Antagonist & Pain & Hyperthermia & {$[84,159]$} \\
\hline & Antagonist & Seizures & Hyperthermia & {$[92,93]$} \\
\hline
\end{tabular}


Supplementary Materials: The following are available online at http:/ / www.mdpi.com/1422-0067/21/8/2778/s1, Table S1: Diseases and disorders that could be treated by targeting ECS proteins., Table S2: Possible indications for activation or inhibition of the proteins of ECS.

Author Contributions: Conceptualization, A.S. and J.I.S.; writing-original draft preparation, A.S. and K.Z.; writing-review and editing, M.G., T.P., and J.I.S.; funding acquisition, J.I.S. All authors have read and agreed to the published version of the manuscript.

Funding: This research was funded by European Molecular Biology Organization installation Grant No. 2057 to J.I.S. and YIP EMBO to J.I.S.

Conflicts of Interest: The authors declare no conflict of interest.

\section{Abbreviations}

The following abbreviations are used in this manuscript:

2-AG 2-arachidonoylglycerol

5-HT 5-hydroxytryptamine (serotonin)

5-HT1A serotonin receptor $1 \mathrm{~A}$

5-HT2B serotonin receptor $2 \mathrm{~B}$

5-HT3 serotonin receptor 3

$\triangle$ 9-THC $\quad \Delta$ 9-tetrahydrocannabinol

AA arachidonic acid

ABHD6 $\alpha / \beta$ hydrolase domain 6

ABHD12 $\alpha / \beta$ hydrolase domain 12

AC adenylyl cyclase

ACE angiotensin-converting enzyme

AD Alzheimer disease

AEA N-arachidonoylethanolamine (anandamide)

AIDS acquired immunodeficiency syndrome

ALS amyotrophic lateral sclerosis

AM404 N-arachidonoylaminophenol

AMP adenosine monophosphate

AMPA $\quad \alpha$-amino-3-hydroxy-5-methyl-4-isoxazolepropionic acid

AMPK AMP-activated protein kinase

AMT anandamide membrane transporter

BLA basolateral complex of amygdala

BP blood pressure

cAMP cyclic adenosine monophosphate

CB cannabinoid

CB1 cannabinoid receptor type 1

CB2 cannabinoid receptor type 2

CBD cannabidiol

CBDV cannabidivarin

CBR cannabinoid receptor

CIPN chemotherapy-induced peripheral neuropathy

CNS central nervous system

COX cyclooxygenase

COX-2 cyclooxygenase 2

COX-3 cyclooxygenase 3

CXCR4 C-X-C chemokine receptor type 4

DA dopamine

DAG diacylglycerol

DAGL diacylglycerol lipase

DN diabetic neuropathy

DPP4 dipeptidyl peptidase 4

eCB endocannabinoid 


$\begin{array}{ll}\text { ECS } & \text { endocannabinoid system } \\ \text { ER } & \text { endoplasmic reticulum } \\ \text { ET } & \text { endotoxin tolerance } \\ \text { FAAH } & \text { fatty acid amide hydrolase } \\ \text { FABP } & \text { fatty-acid-binding protein } \\ \text { FCD } & \text { focal cortical dysplasia } \\ \text { FDA } & \text { Food and Drug Administration } \\ \text { GABA } & \gamma \text {-aminobutyric acid } \\ \text { GDP } & \text { guanosine diphosphate } \\ \text { GI } & \text { gastrointestinal } \\ \text { GIT } & \text { gastrointestinal tract } \\ \text { GLUT-2 } & \text { glucose transporter 2 } \\ \text { GPCR } & \text { G protein-coupled receptor } \\ \text { GPR18 } & \text { G protein-coupled receptor } 18 \\ \text { GPR55 } & \text { G protein-coupled receptor } 55 \\ \text { GPR119 } & \text { G protein-coupled receptor } 119 \\ \text { GTP } & \text { guanosine triphosphate }\end{array}$

HAND human immunodeficiency virus associated neurocognitive disorder

HER2 human epidermal growth factor receptor 2

HIV-1 human immunodeficiency virus 1

HPA hypothalamic-pituitary-adrenal axis

HPO hypothalamic-pituitary-ovarian axis

HSP70 $\quad 70$ kilodalton heat shock protein

IBD inflammatory bowel disease

IL-1 $\beta$ interleukin $1 \beta$

IL-6 interleukin 6

IL-18 interleukin 18

IMMA indomethacin morpholinamide

iNOS inducible nitric oxide synthase

IPAH idiopathic pulmonary arterial hypertension

$\mathrm{LHb} \quad$ lateral habenula

LPI lysophosphatidylinositol

LPS lipopolysaccharide (endotoxin)

MAGL monoacylglycerol lipase

MAPK mitogen activated protein kinase

MCP-1 monocyte chemoattractant protein 1

MI myocardial infraction

MOA mechanism of action

mTORC1 mammalian target of rapamycin complex 1

NAAA N-acylethanolamine acid amidase

NAFLD nonalcoholic fatty liver disease

NAM negative allosteric modulator

NAPE N-acylphosphatidylethanolamine

NAPE-PLD N-acylphosphatidylethanolamine-hydrolyzing phospholipase D

$\mathrm{NASH} \quad$ nonalcoholic steatohepatitis

NF- $\kappa$ B nuclear factor $-\kappa B$

NMDA N-methyl-D-aspartate

NOS nitric oxide synthase

NSAID nonsteroidal anti-inflammatory drug

NSC neural stem cell

OEA oleoylethanolamine

OXPKOS oxidative phosphorylation

PAM positive allosteric modulator

PEA palmitoylethanolamide

PG prostaglandin

PGE2 prostaglandin $\mathrm{E}_{2}$ 


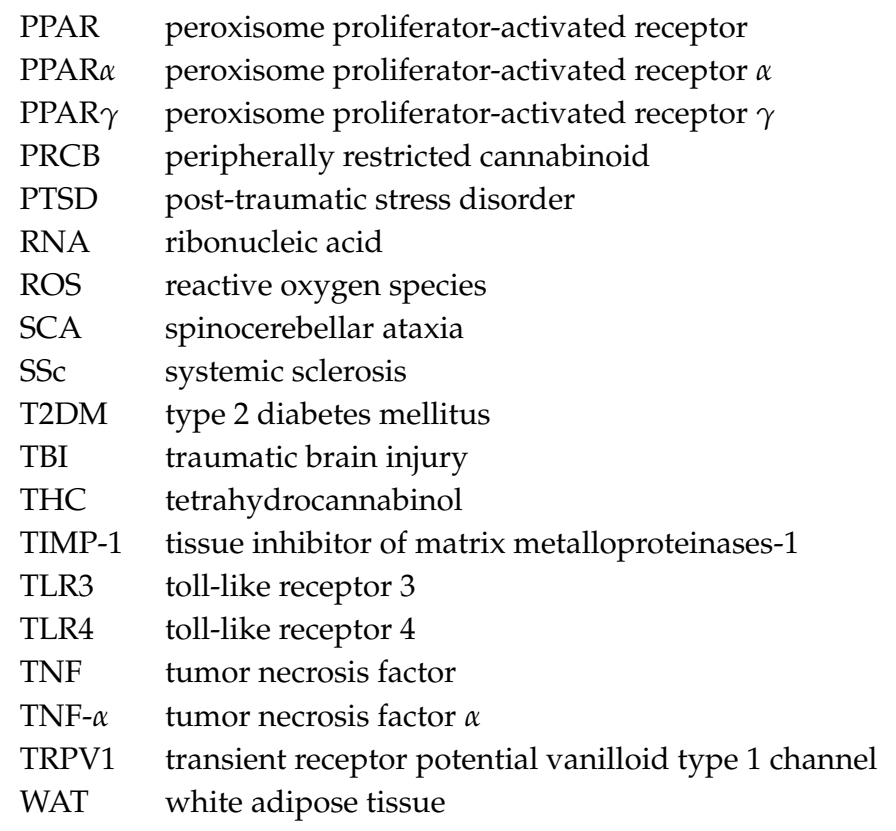

\section{References}

1. Wu, J. Cannabis, cannabinoid receptors, and endocannabinoid system: Yesterday, today, and tomorrow. Acta Pharmacol. Sin. 2019, 40, 297-299. [CrossRef]

2. Gaoni, Y.; Mechoulam, R. Isolation, structure, and partial synthesis of an active constituent of hashish. J. Am. Chem. Soc. 1964, 86, 1646-1647. [CrossRef]

3. Devane, W.A.; Dysarz, F.r.; Johnson, M.R.; Melvin, L.S.; Howlett, A.C. Determination and characterization of a cannabinoid receptor in rat brain. Mol. Pharmacol. 1988, 34, 605-613. [PubMed]

4. Matsuda, L.A.; Lolait, S.J.; Brownstein, M.J.; Young, A.C.; Bonner, T.I. Structure of a cannabinoid receptor and functional expression of the cloned cDNA. Nature 1990, 346, 561-564. [CrossRef] [PubMed]

5. Munro, S.; Thomas, K.L.; Abu-Shaar, M. Molecular characterization of a peripheral receptor for cannabinoids. Nature 1993, 365, 61-65. [CrossRef]

6. Devane, W.A.; Hanus, L.; Breuer, A.; Pertwee, R.G.; Stevenson, L.A.; Griffin, G.; Gibson, D.; Mandelbaum, A.; Etinger, A.; Mechoulam, R. Isolation and structure of a brain constituent that binds to the cannabinoid receptor. Science 1992, 258, 1946-1949. [CrossRef]

7. Ligumsky, M.; Kaminski, N.E.; Schatz, A.R.; Compton, D.R.; Pertwee, R.G.; Griffin, G.; Bayewitch, M.; Barg, J.; Vogel, Z. Identification of an endogenous 2-monoglyceride, present in canine gut that binds to cannabinoid receptors. Biochem. Pharmacol. 1995, 50, 83-90.

8. Busquets-Garcia, A.; Bains, J.; Marsicano, G. CB 1 receptor signaling in the brain: Extracting specificity from ubiquity. Neuropsychopharmacology 2018, 43, 4-20. [CrossRef]

9. Galiègue, S.; Mary, S.; Marchand, J.; Dussossoy, D.; Carrière, D.; Carayon, P.; Bouaboula, M.; Shire, D.; LE Fur, G.; Casellas, P. Expression of central and peripheral cannabinoid receptors in human immune tissues and leukocyte subpopulations. Eur. J. Biochem. 1995, 232, 54-61. [CrossRef]

10. Sam, A.H.; Salem, V.; Ghatei, M.A. Rimonabant: From RIO to ban. J. Obes. 2011, 2011, 432607. [CrossRef]

11. Navarro, M.; Hernández, E.; Muñoz, R.M.; del Arco, I.; Villanúa, M.A.; Carrera, M.R.A.; de Fonseca, F.R. Acute administration of the CB1 cannabinoid receptor antagonist SR 141716A induces anxiety-like responses in the rat. Neuroreport 1997, 8, 491-496. [CrossRef] [PubMed]

12. Bridgeman, M.B.; Abazia, D.T. Medicinal cannabis: History, pharmacology, and implications for the acute care setting. Pharm. Ther. 2017, 42, 180-188.

13. Aviram, J.; Samuelly-Leichtag, G. Efficacy of Cannabis-Based Medicines for Pain Management: A Systematic Review and Meta-Analysis of Randomized Controlled Trials. Pain Physician 2017, 20, E755-E796. [PubMed] 
14. Stockings, E.; Campbell, G.; Hall, W.D.; Nielsen, S.; Zagic, D.; Rahman, R.; Murnion, B.; Farrell, M.; Weier, M.; Degenhardt, L. Cannabis and cannabinoids for the treatment of people with chronic noncancer pain conditions: A systematic review and meta-analysis of controlled and observational studies. Pain 2018, 159, 1932-1954. [CrossRef] [PubMed]

15. Russo, E.B. Beyond cannabis: Plants and the endocannabinoid system. Trends Pharmacol. Sci. 2016, 37, 594-605. [CrossRef]

16. Green, K.; Drvota, V.; Vesterqvist, O. Pronounced reduction of in vivo prostacyclin synthesis in humans by acetaminophen (paracetamol). Prostaglandins 1989, 37, 311-315. [CrossRef]

17. Botting, R.M. Mechanism of action of acetaminophen: Is there a cyclooxygenase 3? Clin. Infect. Dis. 2000, 31, S202-S210. [CrossRef]

18. Ouellet, M.; Percival, M.D. Mechanism of acetaminophen inhibition of cyclooxygenase isoforms. Arch. Biochem. Biophys. 2001, 387, 273-280. [CrossRef]

19. Botting, R.; Ayoub, S.S. COX-3 and the mechanism of action of paracetamol/acetaminophen. Prostaglandins, Leukot. Essent. Fat. Acids 2005, 72, 85-87. [CrossRef]

20. Alloui, A.; Chassaing, C.; Schmidt, J.; Ardid, D.; Dubray, C.; Cloarec, A.; Eschalier, A. Paracetamol exerts a spinal, tropisetron-reversible, antinociceptive effect in an inflammatory pain model in rats. Eur. J. Pharmacol. 2002, 443, 71-77. [CrossRef]

21. Pickering, G.; Loriot, M.A.; Libert, F.; Eschalier, A.; Beaune, P.; Dubray, C. Analgesic effect of acetaminophen in humans: First, evidence of a central serotonergic mechanism. Clin. Pharmacol. Ther. 2006, 79, 371-378. [CrossRef] [PubMed]

22. Godfrey, L.; Bailey, I.; Toms, N.J.; Clarke, G.D.; Kitchen, I.; Hourani, S.M. Paracetamol inhibits nitric oxide synthesis in murine spinal cord slices. Eur. J. Pharmacol. 2007, 562, 68-71. [CrossRef] [PubMed]

23. Ottani, A.; Leone, S.; Sandrini, M.; Ferrari, A.; Bertolini, A. The analgesic activity of paracetamol is prevented by the blockade of cannabinoid CB1 receptors. Eur. J. Pharmacol. 2006, 531, 280-281. [CrossRef] [PubMed]

24. Sharma, C.V.; Long, J.H.; Shah, S.; Rahman, J.; Perrett, D.; Ayoub, S.S.; Mehta, V. First, evidence of the conversion of paracetamol to AM404 in human cerebrospinal fluid. J. Pain Res. 2017, 10, 2703-2709. [CrossRef]

25. Beltramo, M.; Stella, N.; Calignano, A.; Lin, S.; Makriyannis, A.; Piomelli, D. Functional role of high-affinity anandamide transport, as revealed by selective inhibition. Science 1997, 277, 1094-1097. [CrossRef]

26. Sinning, C.; Watzer, B.; Coste, O.; Nusing, R.M.; Ott, I.; Ligresti, A.; Marzo, V.D.; Imming, P. New analgesics synthetically derived from the paracetamol metabolite $\mathrm{N}$-(4-hydroxyphenyl)-(5 Z, $8 \mathrm{Z}, 11 \mathrm{Z}, 14 \mathrm{Z})$-icosatetra-5, 8, 11, 14-enamide. J. Med. Chem. 2008, 51, 7800-7805. [CrossRef]

27. Stueber, T.; Meyer, S.; Jangra, A.; Hage, A.; Eberhardt, M.; Leffler, A. Activation of the capsaicin-receptor TRPV1 by the acetaminophen metabolite N-arachidonoylaminophenol results in cytotoxicity. Life Sci. 2018, 194, 67-74. [CrossRef]

28. Rogosch, T.; Sinning, C.; Podlewski, A.; Watzer, B.; Schlosburg, J.; Lichtman, A.H.; Cascio, M.G.; Bisogno, T.; Di Marzo, V.; Nüsing, R.; et al. Novel bioactive metabolites of dipyrone (metamizol). Bioorganic Med. Chem. 2012, 20, 101-107. [CrossRef]

29. Crunfli, F.; Vilela, F.C.; Giusti-Paiva, A. Cannabinoid CB1 receptors mediate the effects of dipyrone. Clin. Exp. Pharmacol. Physiol. 2015, 42, 246-255. [CrossRef]

30. Priestley, R.S.; Nickolls, S.A.; Alexander, S.P.; Kendall, D.A. A potential role for cannabinoid receptors in the therapeutic action of fenofibrate. FASEB J. 2015, 29, 1446-1455. [CrossRef]

31. Hua, T.; Vemuri, K.; Pu, M.; Qu, L.; Han, G.W.; Wu, Y.; Zhao, S.; Shui, W.; Li, S.; Korde, A.; et al. Crystal structure of the human cannabinoid receptor CB1. Cell 2016, 167, 750-762. [CrossRef] [PubMed]

32. Li, X.; Hua, T.; Vemuri, K.; Ho, J.H.; Wu, Y.; Wu, L.; Popov, P.; Benchama, O.; Zvonok, N.; Qu, L.; et al. Crystal structure of the human cannabinoid receptor CB2. Cell 2019, 176, 459-467. [CrossRef] [PubMed]

33. Di Marzo, V. New approaches and challenges to targeting the endocannabinoid system. Nat. Rev. Drug Discov. 2018, 17, 623-639. [CrossRef] [PubMed]

34. Ligresti, A.; De Petrocellis, L.; Di Marzo, V. From phytocannabinoids to cannabinoid receptors and endocannabinoids: Pleiotropic physiological and pathological roles through complex pharmacology. Physiol. Rev. 2016, 96, 1593-1659. [CrossRef] [PubMed] 
35. Aizpurua-Olaizola, O.; Elezgarai, I.; Rico-Barrio, I.; Zarandona, I.; Etxebarria, N.; Usobiaga, A. Targeting the endocannabinoid system: Future therapeutic strategies. Drug Discov. Today 2017, 22, 105-110. [CrossRef] [PubMed]

36. Fezza, F.; Bari, M.; Florio, R.; Talamonti, E.; Feole, M.; Maccarrone, M. Endocannabinoids, related compounds and their metabolic routes. Molecules 2014, 19, 17078-17106. [CrossRef]

37. Murataeva, N.; Straiker, A.; Mackie, K. Parsing the players: 2-arachidonoylglycerol synthesis and degradation in the CNS. Br. J. Pharmacol. 2014, 171, 1379-1391. [CrossRef]

38. Maccarrone, M. Metabolism of the endocannabinoid anandamide: Open questions after 25 years. Front. Mol. Neurosci. 2017, 10, 166. [CrossRef]

39. McHugh, D.; Page, J.; Dunn, E.; Bradshaw, H.B. $\Delta$ 9-Tetrahydrocannabinol and N-arachidonyl glycine are full agonists at GPR18 receptors and induce migration in human endometrial HEC-1B cells. Br. J. Pharmacol. 2012, 165, 2414-2424. [CrossRef]

40. Ryberg, E.; Larsson, N.; Sjögren, S.; Hjorth, S.; Hermansson, N.O.; Leonova, J.; Elebring, T.; Nilsson, K.; Drmota, T.; Greasley, P. The orphan receptor GPR55 is a novel cannabinoid receptor. Br. J. Pharmacol. 2007, 152, 1092-1101. [CrossRef]

41. Godlewski, G.; Offertáler, L.; Wagner, J.A.; Kunos, G. Receptors for acylethanolamides—GPR55 and GPR119. Prostaglandins Other Lipid Mediat. 2009, 89, 105-111. [CrossRef] [PubMed]

42. Muller, C.; Morales, P.; Reggio, P.H. Cannabinoid ligands targeting TRP channels. Front. Mol. Neurosci. 2018, 11, 487. [CrossRef] [PubMed]

43. O'Sullivan, S.E. An update on PPAR activation by cannabinoids. Br. J. Pharmacol. 2016, 173, $1899-1910$. [CrossRef] [PubMed]

44. Rossi, F.; Tortora, C.; Punzo, F.; Bellini, G.; Argenziano, M.; Di Paola, A.; Torella, M.; Perrotta, S. The Endocannabinoid/Endovanilloid System in Bone: From Osteoporosis to Osteosarcoma. Int. J. Mol. Sci. 2019, 20, 1919. [CrossRef]

45. Zou, S.; Kumar, U. Cannabinoid receptors and the endocannabinoid system: Signaling and function in the central nervous system. Int. J. Mol. Sci. 2018, 19, 833.

46. Kind, L.; Kursula, P. Structural properties and role of the endocannabinoid lipases ABHD6 and ABHD12 in lipid signaling and disease. Amino Acids 2019, 51, 151-174. [CrossRef]

47. Yang, F.; Zheng, J. Understand spiciness: Mechanism of TRPV1 channel activation by capsaicin. Protein Cell 2017, 8, 169-177. [CrossRef]

48. Al-Zoubi, R.; Morales, P.; Reggio, P.H. Structural insights into CB1 receptor biased signaling. Int. J. Mol. Sci. 2019, 20, 1837. [CrossRef]

49. Bouaboula, M.; Perrachon, S.; Milligan, L.; Canat, X.; Rinaldi-Carmona, M.; Portier, M.; Barth, F.; Calandra, B.; Pecceu, F.; Lupker, J.; et al. A Selective Inverse Agonist for Central Cannabinoid Receptor Inhibits Mitogen-activated Protein Kinase Activation Stimulated by Insulin or Insulin-like Growth Factor 1. Evidence for a new model of receptor/ligand interactions. J. Biol. Chem. 1997, 272, 22330-22339. [CrossRef]

50. Console-Bram, L.; Marcu, J.; Abood, M.E. Cannabinoid receptors: Nomenclature and pharmacological principles. Prog. Neuro-Psychopharmacol. Biol. Psychiatry 2012, 38, 4-15. [CrossRef]

51. Meye, F.; Trezza, V.; Vanderschuren, L.J.; Ramakers, G.; Adan, R. Neutral antagonism at the cannabinoid 1 receptor: A safer treatment for obesity. Mol. Psychiatry 2013, 18, 1294-1301. [CrossRef] [PubMed]

52. Bosier, B.; Muccioli, G.G.; Hermans, E.; Lambert, D.M. Functionally selective cannabinoid receptor signaling: Therapeutic implications and opportunities. Biochem. Pharmacol. 2010, 80, 1-12. [CrossRef] [PubMed]

53. Ibsen, M.S.; Connor, M.; Glass, M. Cannabinoid CB1 and CB2 receptor signaling and bias. Cannabis Cannabinoid Res. 2017, 2, 48-60. [CrossRef] [PubMed]

54. Syrovatkina, V.; Alegre, K.O.; Dey, R.; Huang, X.Y. Regulation, signaling, and physiological functions of G-proteins. J. Mol. Biol. 2016, 428, 3850-3868. [CrossRef]

55. Ford, B.M.; Franks, L.N.; Tai, S.; Fantegrossi, W.E.; Stahl, E.L.; Berquist, M.D.; Cabanlong, C.V.; Wilson, C.D.; Penthala, N.R.; Crooks, P.A.; et al. Characterization of structurally novel G protein biased CB1 agonists: Implications for drug development. Pharmacol. Res. 2017, 125, 161-177. [CrossRef]

56. Shore, D.M.; Baillie, G.L.; Hurst, D.H.; Navas, F.; Seltzman, H.H.; Marcu, J.P.; Abood, M.E.; Ross, R.A.; Reggio, P.H. Allosteric modulation of a cannabinoid G protein-coupled receptor binding site elucidation and relationship to G protein signaling. J. Biol. Chem. 2014, 289, 5828-5845. [CrossRef] 
57. Shao, Z.; Yan, W.; Chapman, K.; Ramesh, K.; Ferrell, A.J.; Yin, J.; Wang, X.; Xu, Q.; Rosenbaum, D.M. Structure of an allosteric modulator bound to the CB1 cannabinoid receptor. Nat. Chem. Biol. 2019, 15, 1199-1205. [CrossRef]

58. Pandey, P.; Roy, K.K.; Doerksen, R.J. Negative allosteric modulators of cannabinoid receptor 2: Protein modeling, binding site identification and molecular dynamics simulations in the presence of an orthosteric agonist. J. Biomol. Struct. Dyn. 2020, 38, 32-47. [CrossRef]

59. Kenakin, T.; Miller, L.J. Seven transmembrane receptors as shapeshifting proteins: The impact of allosteric modulation and functional selectivity on new drug discovery. Pharmacol. Rev. 2010, 62, 265-304. [CrossRef]

60. May, L.T.; Leach, K.; Sexton, P.M.; Christopoulos, A. Allosteric modulation of G protein-coupled receptors. Annu. Rev. Pharmacol. Toxicol. 2007, 47, 1-51. [CrossRef]

61. Conn, P.J.; Christopoulos, A.; Lindsley, C.W. Allosteric modulators of GPCRs: A novel approach for the treatment of CNS disorders. Nat. Rev. Drug Discov. 2009, 8, 41-54. [CrossRef]

62. Nguyen, T.; Li, J.X.; Thomas, B.F.; Wiley, J.L.; Kenakin, T.P.; Zhang, Y. Allosteric modulation: An alternate approach targeting the cannabinoid CB1 receptor. Med. Res. Rev. 2017, 37, 441-474. [CrossRef]

63. Gado, F.; Meini, S.; Bertini, S.; Digiacomo, M.; Macchia, M.; Manera, C. Allosteric modulators targeting cannabinoid cb1 and cb2 receptors: implications for drug discovery. Future Med. Chem. 2019, 11, 2019-2037. [CrossRef] [PubMed]

64. Ahn, K.H.; Mahmoud, M.M.; Shim, J.Y.; Kendall, D.A. Distinct roles of $\beta$-arrestin 1 and $\beta$-arrestin 2 in ORG27569-induced biased signaling and internalization of the cannabinoid receptor 1 (CB1). J. Biol. Chem. 2013, 288, 9790-9800. [CrossRef] [PubMed]

65. Khurana, L.; Mackie, K.; Piomelli, D.; Kendall, D.A. Modulation of CB1 cannabinoid receptor by allosteric ligands: pharmacology and therapeutic opportunities. Neuropharmacology 2017, 124, 3-12. [CrossRef] [PubMed]

66. Gil-Ordóñez, A.; Martín-Fontecha, M.; Ortega-Gutiérrez, S.; López-Rodríguez, M.L. Monoacylglycerol lipase (MAGL) as a promising therapeutic target. Biochem. Pharmacol. 2018, 157, 18-32. [CrossRef]

67. Tripathi, R.K.P. A perspective review on fatty acid amide hydrolase (FAAH) inhibitors as potential therapeutic agents. Eur. J. Med. Chem. 2020, 188, 111953. [CrossRef]

68. Schlosburg, J.E.; Blankman, J.L.; Long, J.Z.; Nomura, D.K.; Pan, B.; Kinsey, S.G.; Nguyen, P.T.; Ramesh, D.; Booker, L.; Burston, J.J.; et al. Chronic monoacylglycerol lipase blockade causes functional antagonism of the endocannabinoid system. Nat. Neurosci. 2010, 13, 1113-1119. [CrossRef]

69. Dainese, E.; Oddi, S.; Simonetti, M.; Sabatucci, A.; Angelucci, C.B.; Ballone, A.; Dufrusine, B.; Fezza, F.; De Fabritiis, G.; Maccarrone, M. The endocannabinoid hydrolase FAAH is an allosteric enzyme. Sci. Rep. 2020, 10, 2292. [CrossRef]

70. Caterina, M.J.; Schumacher, M.A.; Tominaga, M.; Rosen, T.A.; Levine, J.D.; Julius, D. The capsaicin receptor: A heat-activated ion channel in the pain pathway. Nature 1997, 389, 816-824. [CrossRef]

71. Diaz-Franulic, I.; Poblete, H.; Miño-Galaz, G.; González, C.; Latorre, R. Allosterism and structure in thermally activated transient receptor potential channels. Annu. Rev. Biophys. 2016, 45, 371-398. [CrossRef] [PubMed]

72. Manzanares, J.; Julian, M.; Carrascosa, A. Role of the cannabinoid system in pain control and therapeutic implications for the management of acute and chronic pain episodes. Curr. Neuropharmacol. 2006, 4, 239-257. [CrossRef] [PubMed]

73. Guindon, J.; Hohmann, A.G. The endocannabinoid system and pain. CNS Neurol. Disord. Drug Targets 2009, 8, 403-421. [CrossRef] [PubMed]

74. Donvito, G.; Nass, S.R.; Wilkerson, J.L.; Curry, Z.A.; Schurman, L.D.; Kinsey, S.G.; Lichtman, A.H. The endogenous cannabinoid system: A budding source of targets for treating inflammatory and neuropathic pain. Neuropsychopharmacology 2018, 43, 52-79. [CrossRef]

75. Puighermanal, E.; Busquets-Garcia, A.; Maldonado, R.; Ozaita, A. Cellular and intracellular mechanisms involved in the cognitive impairment of cannabinoids. Philos. Trans. R. Soc. B: Biol. Sci. 2012, 367, 3254-3263. [CrossRef]

76. Wiskerke, J.; Pattij, T.; Schoffelmeer, A.N.; De Vries, T.J. The role of CB1 receptors in psychostimulant addiction. Addict. Biol. 2008, 13, 225-238. [CrossRef]

77. Parsons, L.H.; Hurd, Y.L. Endocannabinoid signaling in reward and addiction. Nat. Rev. Neurosci. 2015, 16, 579-594. [CrossRef] 
78. Mulpuri, Y.; Marty, V.N.; Munier, J.J.; Mackie, K.; Schmidt, B.L.; Seltzman, H.H.; Spigelman, I. Synthetic peripherally-restricted cannabinoid suppresses chemotherapy-induced peripheral neuropathy pain symptoms by CB1 receptor activation. Neuropharmacology 2018, 139, 85-97. [CrossRef]

79. Slivicki, R.A.; Xu, Z.; Kulkarni, P.M.; Pertwee, R.G.; Mackie, K.; Thakur, G.A.; Hohmann, A.G. Positive allosteric modulation of cannabinoid receptor type 1 suppresses pathological pain without producing tolerance or dependence. Biol. Psychiatry 2018, 84, 722-733. [CrossRef]

80. Nent, E.; Nozaki, C.; Schmöle, A.C.; Otte, D.; Zimmer, A. CB2 receptor deletion on myeloid cells enhanced mechanical allodynia in a mouse model of neuropathic pain. Sci. Rep. 2019, 9, 7468. [CrossRef]

81. Gado, F.; Di Cesare Mannelli, L.; Lucarini, E.; Bertini, S.; Cappelli, E.; Digiacomo, M.; Stevenson, L.A.; Macchia, M.; Tuccinardi, T.; Ghelardini, C.; et al. Identification of the first synthetic allosteric modulator of the CB2 receptors and evidence of its efficacy for neuropathic pain relief. J. Med. Chem. 2019, 62, $276-287$. [CrossRef] [PubMed]

82. Clapper, J.R.; Henry, C.L.; Niphakis, M.J.; Knize, A.M.; Coppola, A.R.; Simon, G.M.; Ngo, N.; Herbst, R.A.; Herbst, D.M.; Reed, A.W.; et al. Monoacylglycerol lipase inhibition in human and rodent systems supports clinical evaluation of endocannabinoid modulators. J. Pharmacol. Exp. Ther. 2018, 367, 494-508. [CrossRef] [PubMed]

83. Brindisi, M.; Borrelli, G.; Brogi, S.; Grillo, A.; Maramai, S.; Paolino, M.; Benedusi, M.; Pecorelli, A.; Valacchi, G.; Di Cesare Mannelli, L.; et al. Development of Potent Inhibitors of Fatty Acid Amide Hydrolase Useful for the Treatment of Neuropathic Pain. ChemMedChem 2018, 13, 2090-2103. [CrossRef] [PubMed]

84. Malek, N.; Starowicz, K. Dual-acting compounds targeting endocannabinoid and endovanilloid systems-A novel treatment option for chronic pain management. Front. Pharmacol. 2016, 7, 257. [CrossRef] [PubMed]

85. da Fonseca Pacheco, D.; Romero, T.R.L.; Duarte, I.D.G. Ketamine induces central antinociception mediated by endogenous cannabinoids and activation of CB1 receptors. Neurosci. Lett. 2019, 699, 140-144. [CrossRef] [PubMed]

86. Jones, M.; Wen, J.; Selvaraj, P.; Tanaka, M.; Moran, S.; Zhang, Y. Therapeutic effect of the substrate-selective COX-2 inhibitor IMMA in the animal model of chronic constriction injury. Front. Pharmacol. 2018, 9, 1481. [CrossRef]

87. Almeida-Santos, A.F.; Ferreira, R.C.; Duarte, I.D.; Aguiar, D.C.; Romero, T.R.; Moreira, F.A. The antipsychotic aripiprazole induces antinociceptive effects: Possible role of peripheral dopamine D2 and serotonin 5-HT1A receptors. Eur. J. Pharmacol. 2015, 765, 300-306. [CrossRef]

88. Ferreira, R.C.; Almeida-Santos, A.F.; Duarte, I.D.; Aguiar, D.C.; Moreira, F.A.; Romero, T.R. Role of Endocannabinoid System in the Peripheral Antinociceptive Action of Aripiprazole. Anesth. Analg. 2019, 129, 263-268. [CrossRef]

89. Fei, L.; Abrardi, L.; Mediati, R.D. Unexpected effect of aripiprazole on nociceptive pain. Ther. Adv. Psychopharmacol. 2012, 2, 211-212. [CrossRef]

90. Russo, E.B. Cannabis and epilepsy: An ancient treatment returns to the fore. Epilepsy Behav. 2017, 70, $292-297$. [CrossRef]

91. Colangeli, R.; Di Maio, R.; Pierucci, M.; Deidda, G.; Casarrubea, M.; Di Giovanni, G. Synergistic action of CB1 and 5-HT2B receptors in preventing pilocarpine-induced status epilepticus in rats. Neurobiol. Dis. 2019, 125, 135-145. [CrossRef] [PubMed]

92. Zareie, P.; Sadegh, M.; Palizvan, M.R.; Moradi-Chameh, H. Anticonvulsive effects of endocannabinoids; an investigation to determine the role of regulatory components of endocannabinoid metabolism in the Pentylenetetrazol induced tonic-clonic seizures. Metab. Brain Dis. 2018, 33, 939-948. [CrossRef] [PubMed]

93. Manna, S.S.; Umathe, S.N. Involvement of transient receptor potential vanilloid type 1 channels in the pro-convulsant effect of anandamide in pentylenetetrazole-induced seizures. Epilepsy Res. 2012, 100, 113-124. [CrossRef] [PubMed]

94. Starowicz, K.; Makuch, W.; Korostynski, M.; Malek, N.; Slezak, M.; Zychowska, M.; Petrosino, S.; De Petrocellis, L.; Cristino, L.; Przewlocka, B.; et al. Full inhibition of spinal FAAH leads to TRPV1-mediated analgesic effects in neuropathic rats and possible lipoxygenase-mediated remodeling of anandamide metabolism. PLoS ONE 2013, 8, e60040. [CrossRef] [PubMed]

95. Wei, M.; Zhang, J.; Jia, M.; Yang, C.; Pan, Y.; Li, S.; Luo, Y.; Zheng, J.; Ji, J.; Chen, J.; et al. $\alpha / \beta$-Hydrolase domain-containing 6 (ABHD6) negatively regulates the surface delivery and synaptic function of AMPA receptors. Proc. Natl. Acad. Sci. USA 2016, 113, E2695-E2704. [CrossRef] [PubMed] 
96. Deshpande, L.S.; DeLorenzo, R.J. Acetaminophen inhibits status epilepticus in cultured hippocampal neurons. Neuroreport 2011, 22, 15-18. [CrossRef]

97. Suemaru, K.; Yoshikawa, M.; Tanaka, A.; Araki, H.; Aso, H.; Watanabe, M. Anticonvulsant effects of acetaminophen in mice: Comparison with the effects of nonsteroidal anti-inflammatory drugs. Epilepsy Res. 2018, 140, 22-28. [CrossRef]

98. Suemaru, K.; Yoshikawa, M.; Aso, H.; Watanabe, M. TRPV1 mediates the anticonvulsant effects of acetaminophen in mice. Epilepsy Res. 2018, 145, 153-159. [CrossRef]

99. Whalley, B.J.; Lin, H.; Bell, L.; Hill, T.; Patel, A.; Gray, R.A.; Roberts, C.E.; Devinsky, O.; Bazelot, M.; Williams, C.M.; et al. Species-specific susceptibility to cannabis-induced convulsions. Br. J. Pharmacol. 2019, 176, 1506-1523. [CrossRef]

100. Greenwich Biosciences. EPIDIOLEX (cannabidiol) [drug label]. Revised June 2018. Available online: https:/ / www.accessdata.fda.gov/drugsatfda_docs/label/2018/210365lbl.pdf (accessed on 18 February 2020).

101. Bisogno, T.; Hanuš, L.; De Petrocellis, L.; Tchilibon, S.; Ponde, D.E.; Brandi, I.; Moriello, A.S.; Davis, J.B.; Mechoulam, R.; Di Marzo, V. Molecular targets for cannabidiol and its synthetic analogues: Effect on vanilloid VR1 receptors and on the cellular uptake and enzymatic hydrolysis of anandamide. Br. J. Pharmacol. 2001, 134, 845-852. [CrossRef]

102. Russo, E.B.; Burnett, A.; Hall, B.; Parker, K.K. Agonistic properties of cannabidiol at 5-HT1a receptors. Neurochem. Res. 2005, 30, 1037-1043. [CrossRef] [PubMed]

103. Laprairie, R.; Bagher, A.; Kelly, M.; Denovan-Wright, E. Cannabidiol is a negative allosteric modulator of the cannabinoid CB1 receptor. Br. J. Pharmacol. 2015, 172, 4790-4805. [CrossRef] [PubMed]

104. Bih, C.I.; Chen, T.; Nunn, A.V.; Bazelot, M.; Dallas, M.; Whalley, B.J. Molecular targets of cannabidiol in neurological disorders. Neurotherapeutics 2015, 12, 699-730.

105. Gaston, T.E.; Friedman, D. Pharmacology of cannabinoids in the treatment of epilepsy. Epilepsy Behav. 2017, 70, 313-318. [CrossRef]

106. Hill, M.N.; Gorzalka, B.B. The endocannabinoid system and the treatment of mood and anxiety disorders. CNS Neurol. Disord.-Drug Targets 2009, 8, 451-458. [CrossRef]

107. Jacob, W.; Yassouridis, A.; Marsicano, G.; Monory, K.; Lutz, B.; Wotjak, C. Endocannabinoids render exploratory behaviour largely independent of the test aversiveness: Role of glutamatergic transmission. Genes, Brain Behav. 2009, 8, 685-698. [CrossRef]

108. Moreira, F.A.; Grieb, M.; Lutz, B. Central side-effects of therapies based on CB1 cannabinoid receptor agonists and antagonists: Focus on anxiety and depression. Best Pract. Res. Clin. Endocrinol. Metab. 2009, 23, 133-144. [CrossRef]

109. Fraguas-Sánchez, A.I.; Torres-Suárez, A.I. Medical use of cannabinoids. Drugs 2018, 78, 1665-1703. [CrossRef]

110. Cohen, K.; Weizman, A.; Weinstein, A. Positive and negative effects of cannabis and cannabinoids on health. Clin. Pharmacol. Ther. 2019, 105, 1139-1147. [CrossRef]

111. Viana, T.G.; Bastos, J.R.; Costa, R.B.; Hott, S.C.; Mansur, F.S.; Coimbra, C.C.; Resstel, L.B.; Aguiar, D.C.; Moreira, F.A. Hypothalamic endocannabinoid signaling modulates aversive responses related to panic attacks. Neuropharmacology 2019, 148, 284-290. [CrossRef]

112. Zimmermann, T.; Bartsch, J.C.; Beer, A.; Lomazzo, E.; Guggenhuber, S.; Lange, M.D.; Bindila, L.; Pape, H.C.; Lutz, B. Impaired anandamide/palmitoylethanolamide signaling in hippocampal glutamatergic neurons alters synaptic plasticity, learning, and emotional responses. Neuropsychopharmacology 2019, 44, 1377-1388. [CrossRef] [PubMed]

113. Harris, B.N.; Hohman, Z.P.; Campbell, C.M.; King, K.S.; Tucker, C.A. FAAH genotype, CRFR1 genotype, and cortisol interact to predict anxiety in an aging, rural Hispanic population: A Project FRONTIER study. Neurobiol. Stress 2019, 10, 100154. [CrossRef] [PubMed]

114. Gärtner, A.; Dörfel, D.; Diers, K.; Witt, S.H.; Strobel, A.; Brocke, B. Impact of FAAH genetic variation on fronto-amygdala function during emotional processing. Eur. Arch. Psychiatry Clin. Neurosci. 2019, 269, 209-221. [CrossRef] [PubMed]

115. Danandeh, A.; Vozella, V.; Lim, J.; Oveisi, F.; Ramirez, G.L.; Mears, D.; Wynn, G.; Piomelli, D. Effects of fatty acid amide hydrolase inhibitor URB597 in a rat model of trauma-induced long-term anxiety. Psychopharmacology 2018, 235, 3211-3221. [CrossRef] 
116. Mayo, L.M.; Asratian, A.; Lindé, J.; Morena, M.; Haataja, R.; Hammar, V.; Augier, G.; Hill, M.N.; Heilig, M. Elevated anandamide, enhanced recall of fear extinction, and attenuated stress responses following inhibition of fatty acid amide hydrolase (FAAH): A randomized, controlled experimental medicine trial. Biol. Psychiatry 2019, 87, 538-547. [CrossRef]

117. Morena, M.; Aukema, R.J.; Leitl, K.D.; Rashid, A.J.; Vecchiarelli, H.A.; Josselyn, S.A.; Hill, M.N. Upregulation of Anandamide Hydrolysis in the Basolateral Complex of Amygdala Reduces Fear Memory Expression and Indices of Stress and Anxiety. J. Neurosci. 2019, 39, 1275-1292. [CrossRef]

118. Surkin, P.N.; Gallino, S.L.; Luce, V.; Correa, F.; Fernandez-Solari, J.; De Laurentiis, A. Pharmacological augmentation of endocannabinoid signaling reduces the neuroendocrine response to stress. Psychoneuroendocrinology 2018, 87, 131-140. [CrossRef]

119. Berger, A.L.; Henricks, A.M.; Lugo, J.M.; Wright, H.R.; Warrick, C.R.; Sticht, M.A.; Morena, M.; Bonilla, I.; Laredo, S.A.; Craft, R.M.; et al. The lateral habenula directs coping styles under conditions of stress via recruitment of the endocannabinoid system. Biol. Psychiatry 2018, 84, 611-623. [CrossRef]

120. Poleszak, E.; Wośko, S.; Sławińska, K.; Szopa, A.; Wróbel, A.; Serefko, A. Cannabinoids in depressive disorders. Life Sci. 2018, 213, 18-24. [CrossRef]

121. Burstein, O.; Shoshan, N.; Doron, R.; Akirav, I. Cannabinoids prevent depressive-like symptoms and alterations in BDNF expression in a rat model of PTSD. Prog. Neuro-Psychopharmacol. Biol. Psychiatry 2018, 84, 129-139. [CrossRef]

122. Liu, Q.R.; Canseco-Alba, A.; Zhang, H.Y.; Tagliaferro, P.; Chung, M.; Dennis, E.; Sanabria, B.; Schanz, N.; Escosteguy-Neto, J.C.; Ishiguro, H.; et al. Cannabinoid type 2 receptors in dopamine neurons inhibits psychomotor behaviors, alters anxiety, depression and alcohol preference. Sci. Rep. 2017, 7, 17410. [CrossRef] [PubMed]

123. Khakpai, F.; Ebrahimi-Ghiri, M.; Alijanpour, S.; Zarrindast, M.R. Ketamine-induced antidepressant like effects in mice: A possible involvement of cannabinoid system. Biomed. Pharmacother. 2019, 112, 108717. [CrossRef] [PubMed]

124. Shearman, L.; Rosko, K.; Fleischer, R.; Wang, J.; Xu, S.; Tong, X.; Rocha, B.A. Antidepressant-like and anorectic effects of the cannabinoid CB1 receptor inverse agonist AM251 in mice. Behav. Pharmacol. 2003, 14, 573-582. [CrossRef] [PubMed]

125. Beyer, C.E.; Dwyer, J.M.; Piesla, M.J.; Platt, B.J.; Shen, R.; Rahman, Z.; Chan, K.; Manners, M.T.; Samad, T.A.; Kennedy, J.D.; et al. Depression-like phenotype following chronic CB1 receptor antagonism. Neurobiol. Dis. 2010, 39, 148-155. [CrossRef] [PubMed]

126. Wang, Y.; Zhang, X. FAAH inhibition produces antidepressant-like efforts of mice to acute stress via synaptic long-term depression. Behav. Brain Res. 2017, 324, 138-145. [CrossRef]

127. Panlilio, L.V.; Goldberg, S.R.; Justinova, Z. Cannabinoid abuse and addiction: Clinical and preclinical findings. Clin. Pharmacol. Ther. 2015, 97, 616-627. [CrossRef]

128. Maldonado, R.; Berrendero, F.; Ozaita, A.; Robledo, P. Neurochemical basis of cannabis addiction. Neuroscience 2011, 181, 1-17. [CrossRef]

129. He, X.h.; Jordan, C.J.; Vemuri, K.; Bi, G.h.; Zhan, J.; Gardner, E.L.; Makriyannis, A.; Wang, Y.l.; Xi, Z.X. Cannabinoid CB 1 receptor neutral antagonist AM4113 inhibits heroin self-administration without depressive side effects in rats. Acta Pharmacol. Sin. 2019, 40, 365-373. [CrossRef]

130. Balla, A.; Dong, B.; Shilpa, B.M.; Vemuri, K.; Makriyannis, A.; Pandey, S.C.; Sershen, H.; Suckow, R.F.; Vinod, K.Y. Cannabinoid-1 receptor neutral antagonist reduces binge-like alcohol consumption and alcohol-induced accumbal dopaminergic signaling. Neuropharmacology 2018, 131, 200-208. [CrossRef]

131. Jing, L.; Qiu, Y.; Zhang, Y.; Li, J.X. Effects of the cannabinoid CB1 receptor allosteric modulator ORG 27569 on reinstatement of cocaine-and methamphetamine-seeking behavior in rats. Drug Alcohol Depend. 2014, 143, 251-256. [CrossRef]

132. Gamage, T.F.; Ignatowska-Jankowska, B.M.; Wiley, J.L.; Abdelrahman, M.; Trembleau, L.; Greig, I.R.; Thakur, G.A.; Tichkule, R.; Poklis, J.; Ross, R.A.; et al. In-vivo pharmacological evaluation of the CB1-receptor allosteric modulator Org-27569. Behav. Pharmacol. 2014, 25, 182-185. [CrossRef] [PubMed]

133. Godlewski, G.; Cinar, R.; Coffey, N.J.; Liu, J.; Jourdan, T.; Mukhopadhyay, B.; Chedester, L.; Liu, Z.; Osei-Hyiaman, D.; Iyer, M.R.; et al. Targeting Peripheral CB1 Receptors Reduces Ethanol Intake via a Gut-Brain Axis. Cell Metab. 2019, 29, 1320-1333. [CrossRef] [PubMed] 
134. Ferreira, J.V.; Chaves, G.A.; Marino, B.L.; Sousa, K.P.; Souza, L.R.; Brito, M.F.; Teixeira, H.R.; da Silva, C.H.; Santos, C.B.; Hage-Melim, L.I. Cannabinoid type 1 receptor (CB1) ligands with therapeutic potential for withdrawal syndrome in chemical dependents of Cannabis sativa. ChemMedChem 2017, 12, 1408-1416. [CrossRef] [PubMed]

135. Trexler, K.; Eckard, M.; Kinsey, S. CB1 positive allosteric modulation attenuates $\triangle 9$-THC withdrawal and NSAID-induced gastric inflammation. Pharmacol. Biochem. Behav. 2019, 177, 27-33. [CrossRef]

136. Centanni, S.W.; Morris, B.D.; Luchsinger, J.R.; Bedse, G.; Fetterly, T.L.; Patel, S.; Winder, D.G. Endocannabinoid control of the insular-bed nucleus of the stria terminalis circuit regulates negative affective behavior associated with alcohol abstinence. Neuropsychopharmacology 2019, 44, 526-537. [CrossRef]

137. Raichlen, D.A.; Foster, A.D.; Gerdeman, G.L.; Seillier, A.; Giuffrida, A. Wired to run: Exercise-induced endocannabinoid signaling in humans and cursorial mammals with implications for the 'runner's high'. J. Exp. Biol. 2012, 215, 1331-1336. [CrossRef]

138. Stone, N.L.; Millar, S.A.; Herrod, P.J.; Barrett, D.A.; Ortori, C.A.; Mellon, V.A.; O'Sullivan, S.E. An analysis of endocannabinoid concentrations and mood following singing and exercise in healthy volunteers. Front. Behav. Neurosci. 2018, 12, 269. [CrossRef]

139. Onaivi, E.S.; Ishiguro, H.; GONG, J.P.; Patel, S.; Perchuk, A.; Meozzi, P.A.; Myers, L.; Mora, Z.; Tagliaferro, P.; Gardner, E.; et al. Discovery of the presence and functional expression of cannabinoid CB2 receptors in brain. Ann. New York Acad. Sci. 2006, 1074, 514-536. [CrossRef]

140. Zhang, H.Y.; Gao, M.; Liu, Q.R.; Bi, G.H.; Li, X.; Yang, H.J.; Gardner, E.L.; Wu, J.; Xi, Z.X. Cannabinoid CB2 receptors modulate midbrain dopamine neuronal activity and dopamine-related behavior in mice. Proc. Natl. Acad. Sci. USA 2014, 111, E5007-E5015. [CrossRef]

141. Navarrete, F.; García-Gutiérrez, M.S.; Manzanares, J. Pharmacological regulation of cannabinoid CB2 receptor modulates the reinforcing and motivational actions of ethanol. Biochem. Pharmacol. 2018, 157, 227-234. [CrossRef]

142. Gobira, P.H.; Oliveira, A.C.; Gomes, J.S.; da Silveira, V.T.; Asth, L.; Bastos, J.R.; Batista, E.M.; Issy, A.C.; Okine, B.N.; de Oliveira, A.C.; et al. Opposing roles of CB1 and CB2 cannabinoid receptors in the stimulant and rewarding effects of cocaine. Br. J. Pharmacol. 2019, 176, 1541-1551. [CrossRef] [PubMed]

143. Martín-Sánchez, A.; Warnault, V.; Montagud-Romero, S.; Pastor, A.; Mondragón, N.; De La Torre, R.; Valverde, $\mathrm{O}$. Alcohol-induced conditioned place preference is modulated by CB2 cannabinoid receptors and modifies levels of endocannabinoids in the mesocorticolimbic system. Pharmacol. Biochem. Behav. 2019, 183, 22-31. [CrossRef] [PubMed]

144. Carlini, E.; Hamaoui, A.; Bieniek, D.; Korte, F. Effects of $(-)^{\Delta}$ 9-trans-Tetrahydrocannabinol and a Synthetic Derivative on Maze Performance of Rats. Pharmacology 1970, 4, 359-368. [CrossRef] [PubMed]

145. Terranova, J.P.; Storme, J.J.; Lafon, N.; Perio, A.; Rinaldi-Carmona, M.; Le Fur, G.; Soubrie, P. Improvement of memory in rodents by the selective CB1 cannabinoid receptor antagonist, SR 141716. Psychopharmacology 1996, 126, 165-172. [CrossRef]

146. Xu, X.; Jiang, S.; Xu, E.; Wu, X.; Zhao, R. Inhibition of CB1 receptor ameliorates spatial learning and memory impairment in mice with traumatic brain injury. Neurosci. Lett. 2019, 696, 127-131. [CrossRef]

147. Rabbani, M.; Vaseghi, G.; Hajhashemi, V. AM281, Cannabinoid Antagonist/Inverse agonist, ameliorates scopolamine-induced cognitive deficit. Iran. J. Basic Med Sci. 2012, 15, 1106-1110.

148. Navarro-Romero, A.; Vázquez-Oliver, A.; Gomis-González, M.; Garzón-Montesinos, C.; Falcón-Moya, R.; Pastor, A.; Martín-García, E.; Pizarro, N.; Busquets-Garcia, A.; Revest, J.M.; et al. Cannabinoid type-1 receptor blockade restores neurological phenotypes in two models for Down syndrome. Neurobiol. Dis. 2019, 125, 92-106. [CrossRef]

149. Vallée, M.; Vitiello, S.; Bellocchio, L.; Hébert-Chatelain, E.; Monlezun, S.; Martin-Garcia, E.; Kasanetz, F.; Baillie, G.L.; Panin, F.; Cathala, A.; et al. Pregnenolone can protect the brain from cannabis intoxication. Science 2014, 343, 94-98. [CrossRef]

150. Bilkei-Gorzo, A.; Albayram, O.; Draffehn, A.; Michel, K.; Piyanova, A.; Oppenheimer, H.; Dvir-Ginzberg, M.; Rácz, I.; Ulas, T.; Imbeault, S.; et al. A chronic low dose of $\Delta$ 9-tetrahydrocannabinol (THC) restores cognitive function in old mice. Nat. Med. 2017, 23, 782-787. [CrossRef]

151. Gruber, S.A.; Sagar, K.A.; Dahlgren, M.K.; Gonenc, A.; Smith, R.T.; Lambros, A.M.; Cabrera, K.B.; Lukas, S.E. The grass might be greener: Medical marijuana patients exhibit altered brain activity and improved executive function after 3 months of treatment. Front. Pharmacol. 2018, 8, 983. [CrossRef] 
152. Sun, L.; Dong, R.; Xu, X.; Yang, X.; Peng, M. Activation of cannabinoid receptor type 2 attenuates surgery-induced cognitive impairment in mice through anti-inflammatory activity. J. Neuroinflammation 2017, 14, 138. [CrossRef] [PubMed]

153. Campolongo, P.; Morena, M.; Scaccianoce, S.; Trezza, V.; Chiarotti, F.; Schelling, G.; Cuomo, V.; Roozendaal, B. Novelty-induced emotional arousal modulates cannabinoid effects on recognition memory and adrenocortical activity. Neuropsychopharmacology 2013, 38, 1276-1286. [CrossRef]

154. Morena, M.; Roozendaal, B.; Trezza, V.; Ratano, P.; Peloso, A.; Hauer, D.; Atsak, P.; Trabace, L.; Cuomo, V.; McGaugh, J.L.; et al. Endogenous cannabinoid release within prefrontal-limbic pathways affects memory consolidation of emotional training. Proc. Natl. Acad. Sci. USA 2014, 111, 18333-18338. [CrossRef] [PubMed]

155. Morena, M.; Campolongo, P. The endocannabinoid system: An emotional buffer in the modulation of memory function. Neurobiol. Learn. Mem. 2014, 112, 30-43. [CrossRef] [PubMed]

156. Ratano, P.; Petrella, C.; Forti, F.; Passeri, P.P.; Morena, M.; Palmery, M.; Trezza, V.; Severini, C.; Campolongo, $\mathrm{P}$. Pharmacological inhibition of 2-arachidonoilglycerol hydrolysis enhances memory consolidation in rats through CB2 receptor activation and mTOR signaling modulation. Neuropharmacology 2018, 138, 210-218. [CrossRef] [PubMed]

157. Rivera, P.; del Mar Fernández-Arjona, M.; Silva-Peña, D.; Blanco, E.; Vargas, A.; López-Ávalos, M.D.; Grondona, J.M.; Serrano, A.; Pavón, F.J.; de Fonseca, F.R.; et al. Pharmacological blockade of fatty acid amide hydrolase (FAAH) by URB597 improves memory and changes the phenotype of hippocampal microglia despite ethanol exposure. Biochem. Pharmacol. 2018, 157, 244-257. [CrossRef]

158. Contarini, G.; Ferretti, V.; Papaleo, F. Acute administration of URB597 fatty acid amide hydrolase (FAAH) inhibitor prevents attentional impairments by distractors in adolescent mice. Front. Pharmacol. 2019, 10, 787. [CrossRef]

159. Brown, W.; Leff, R.L.; Griffin, A.; Hossack, S.; Aubray, R.; Walker, P.; Chiche, D.A. Safety, pharmacokinetics, and pharmacodynamics study in healthy subjects of oral NEO6860, a modality selective transient receptor potential vanilloid subtype 1 antagonist. J. Pain 2017, 18, 726-738. [CrossRef]

160. Zhong, P.; Wang, W.; Pan, B.; Liu, X.; Zhang, Z.; Long, J.Z.; Zhang, H.T.; Cravatt, B.F.; Liu, Q.S. Monoacylglycerol lipase inhibition blocks chronic stress-induced depressive-like behaviors via activation of mTOR signaling. Neuropsychopharmacology 2014, 39, 1763-1776. [CrossRef]

161. Garcia-Arencibia, M.; Molina-Holgado, E.; Molina-Holgado, F. Effect of endocannabinoid signaling on cell fate: Life, death, differentiation and proliferation of brain cells. Br. J. Pharmacol. 2019, 176, 1361-1369. [CrossRef]

162. Hill, J.D.; Zuluaga-Ramirez, V.; Gajghate, S.; Winfield, M.; Persidsky, Y. Activation of GPR55 increases neural stem cell proliferation and promotes early adult hippocampal neurogenesis. Br. J. Pharmacol. 2018, 175, 3407-3421. [CrossRef] [PubMed]

163. Zimmermann, T.; Maroso, M.; Beer, A.; Baddenhausen, S.; Ludewig, S.; Fan, W.; Vennin, C.; Loch, S.; Berninger, B.; Hofmann, C.; et al. Neural stem cell lineage-specific cannabinoid type-1 receptor regulates neurogenesis and plasticity in the adult mouse hippocampus. Cereb. Cortex 2018, 28, 4454-4471. [CrossRef] [PubMed]

164. de Oliveira, R.W.; Oliveira, C.L.; Guimarães, F.S.; Campos, A.C. Cannabinoid signaling in embryonic and adult neurogenesis: Possible implications for psychiatric and neurological disorders. Acta Neuropsychiatr. 2019, 31, 1-16. [CrossRef] [PubMed]

165. Sanchez-Rodriguez, M.A.; Gomez, O.; Esteban, P.F.; Garcia-Ovejero, D.; Molina-Holgado, E. The endocannabinoid 2-arachidonoylglycerol regulates oligodendrocyte progenitor cell migration. Biochem. Pharmacol. 2018, 157, 180-188. [CrossRef]

166. Bilkei-Gorzo, A.; Albayram, O.; Ativie, F.; Chasan, S.; Zimmer, T.; Bach, K.; Zimmer, A. Cannabinoid 1 receptor signaling on GABAergic neurons influences astrocytes in the ageing brain. PLoS ONE 2018, 13, e0202566. [CrossRef] [PubMed]

167. Ativie, F.; Komorowska, J.A.; Beins, E.; Albayram, Ö.; Zimmer, T.; Zimmer, A.; Tejera, D.; Heneka, M.; Bilkei-Gorzo, A. Cannabinoid 1 Receptor Signaling on Hippocampal GABAergic Neurons Influences Microglial Activity. Front. Mol. Neurosci. 2018, 11, 295. [CrossRef] [PubMed]

168. Flannery, L.E.; Kerr, D.M.; Finn, D.P.; Roche, M. FAAH inhibition attenuates TLR3-mediated hyperthermia, nociceptive-and anxiety-like behaviour in female rats. Behav. Brain Res. 2018, 353, 11-20. [CrossRef] 
169. Aguilera-Portillo, G.; Rangel-López, E.; Villeda-Hernández, J.; Chavarría, A.; Castellanos, P.; Elmazoglu, Z.; Karasu, Ç.; Túnez, I.; Pedraza, G.; Königsberg, M.; et al. The pharmacological inhibition of fatty acid amide hydrolase prevents excitotoxic damage in the rat striatum: Possible involvement of CB1 receptors regulation. Mol. Neurobiol. 2019, 56, 844-856. [CrossRef]

170. Saliba, S.W.; Jauch, H.; Gargouri, B.; Keil, A.; Hurrle, T.; Volz, N.; Mohr, F.; van der Stelt, M.; Bräse, S.; Fiebich, B.L. Anti-neuroinflammatory effects of GPR55 antagonists in LPS-activated primary microglial cells. J. Neuroinflammation 2018, 15, 322. [CrossRef]

171. Aso, E.; Andrés-Benito, P.; Ferrer, I. Genetic deletion of CB1 cannabinoid receptors exacerbates the Alzheimer-like symptoms in a transgenic animal model. Biochem. Pharmacol. 2018, 157, 210-216. [CrossRef]

172. Crunfli, F.; Vrechi, T.A.; Costa, A.P.; Torrão, A.S. Cannabinoid Receptor Type 1 Agonist ACEA Improves Cognitive Deficit on STZ-Induced Neurotoxicity Through Apoptosis Pathway and NO Modulation. Neurotox. Res. 2019, 35, 516-529. [CrossRef] [PubMed]

173. Pamplona, F.A.; Ferreira, J.; de Lima, O.M.; Duarte, F.S.; Bento, A.F.; Forner, S.; Villarinho, J.G.; Bellocchio, L.; Wotjak, C.T.; Lerner, R.; et al. Anti-inflammatory lipoxin A4 is an endogenous allosteric enhancer of CB1 cannabinoid receptor. Proc. Natl. Acad. Sci. USA 2012, 109, 21134-21139. [CrossRef] [PubMed]

174. Fernández-Ruiz, J.; Romero, J.; Velasco, G.; Tolón, R.M.; Ramos, J.A.; Guzmán, M. Cannabinoid CB2 receptor: A new target for controlling neural cell survival? Trends Pharmacol. Sci. 2007, 28, 39-45. [CrossRef] [PubMed]

175. Reyes-Resina, I.; Navarro, G.; Aguinaga, D.; Canela, E.I.; Schoeder, C.T.; Załuski, M.; Kieć-Kononowicz, K.; Saura, C.A.; Müller, C.E.; Franco, R. Molecular and functional interaction between GPR18 and cannabinoid CB2 G-protein-coupled receptors. Relevance in neurodegenerative diseases. Biochem. Pharmacol. 2018, 157, 169-179. [CrossRef] [PubMed]

176. Chen, L.; Yan, Y.; Chen, T.; Zhang, L.; Gao, X.; Du, C.; Du, H. Forsythiaside prevents $\beta$-amyloid-induced hippocampal slice injury by upregulating 2-arachidonoylglycerol via cannabinoid receptor 1-dependent NF- $\kappa$ B pathway. Neurochem. Int. 2019, 125, 57-66. [CrossRef]

177. Balleza-Tapia, H.; Crux, S.; Andrade-Talavera, Y.; Dolz-Gaiton, P.; Papadia, D.; Chen, G.; Johansson, J.; Fisahn, A. TrpV1 receptor activation rescues neuronal function and network gamma oscillations from A $\beta$-induced impairment in mouse hippocampus in vitro. eLife 2018, 7, e37703. [CrossRef]

178. Martínez-Pinilla, E.; Aguinaga, D.; Navarro, G.; Rico, A.J.; Oyarzábal, J.; Sánchez-Arias, J.A.; Lanciego, J.L.; Franco, R. Targeting CB 1 and GPR55 Endocannabinoid Receptors as a Potential Neuroprotective Approach for Parkinson's Disease. Mol. Neurobiol. 2019, 56, 5900-5910. [CrossRef]

179. Viveros-Paredes, J.; Gonzalez-Castañeda, R.; Escalante-Castañeda, A.; Tejeda-Martínez, A.; Castañeda-Achutiguí, F.; Flores-Soto, M. Effect of inhibition of fatty acid amide hydrolase on MPTP-induced dopaminergic neuronal damage. Neurología 2019, 34, 143-152. [CrossRef]

180. Horne, E.A.; Coy, J.; Swinney, K.; Fung, S.; Cherry, A.E.; Marrs, W.R.; Naydenov, A.V.; Lin, Y.H.; Sun, X.; Dirk Keene, C.; et al. Downregulation of cannabinoid receptor 1 from neuropeptide $Y$ interneurons in the basal ganglia of patients with Huntington's disease and mouse models. Eur. J. Neurosci. 2013, 37, 429-440. [CrossRef]

181. Holley, S.M.; Galvan, L.; Kamdjou, T.; Dong, A.; Levine, M.S.; Cepeda, C. Major contribution of somatostatin-expressing interneurons and cannabinoid receptors to increased GABA synaptic activity in the striatum of Huntington's disease mice. Front. Synaptic Neurosci. 2019, 11, 14. [CrossRef]

182. Laprairie, R.B.; Bagher, A.M.; Rourke, J.L.; Zrein, A.; Cairns, E.A.; Kelly, M.E.; Sinal, C.J.; Kulkarni, P.M.; Thakur, G.A.; Denovan-Wright, E.M. Positive allosteric modulation of the type 1 cannabinoid receptor reduces the signs and symptoms of Huntington's disease in the R6/2 mouse model. Neuropharmacology 2019, 151, 1-12. [CrossRef] [PubMed]

183. Covey, D.P.; Dantrassy, H.M.; Yohn, S.E.; Castro, A.; Conn, P.J.; Mateo, Y.; Cheer, J.F. Inhibition of endocannabinoid degradation rectifies motivational and dopaminergic deficits in the Q175 mouse model of Huntington's disease. Neuropsychopharmacology 2018, 43, 2056--2063. [CrossRef] [PubMed]

184. Fernández-Ruiz, J.; Moro, M.A.; Martínez-Orgado, J. Cannabinoids in neurodegenerative disorders and stroke/brain trauma: from preclinical models to clinical applications. Neurotherapeutics 2015, 12, 793-806. [CrossRef]

185. DeSanty, K.; Dar, M.S. Cannabinoid-induced motor incoordination through the cerebellar CB1 receptor in mice. Pharmacol. Biochem. Behav. 2001, 69, 251-259. [CrossRef] 
186. Patel, S.; Hillard, C.J. Cannabinoid CB1 receptor agonists produce cerebellar dysfunction in mice. J. Pharmacol. Exp. Ther. 2001, 297, 629-637.

187. Gómez-Ruiz, M.; Rodriguez-Cueto, C.; Luna-Piñel, E.; Hernández-Gálvez, M.; Fernández-Ruiz, J. Endocannabinoid system in spinocerebellar ataxia type-3 and other autosomal-dominant cerebellar ataxias: Potential role in pathogenesis and expected relevance as neuroprotective targets. Front. Mol. Neurosci. 2019, 12, 94. [CrossRef]

188. Hermes, D.J.; Xu, C.; Poklis, J.L.; Niphakis, M.J.; Cravatt, B.F.; Mackie, K.; Lichtman, A.H.; Ignatowska-Jankowska, B.M.; Fitting, S. Neuroprotective effects of fatty acid amide hydrolase catabolic enzyme inhibition in a HIV-1 Tat model of neuroAIDS. Neuropharmacology 2018, 141, 55-65. [CrossRef] [PubMed]

189. García-Rincón, D.; Díaz-Alonso, J.; Ortega, Z.; de Salas-Quiroga, A.; Paraíso-Luna, J.; Aguareles, J.; Jou, C.; De Prada, I.; Martinez Cerdeño, V.; Aronica, E.; et al. Contribution of altered endocannabinoid system to overactive mTORC1 signaling in focal cortical dysplasia. Front. Pharmacol. 2018, 9, 1508. [CrossRef]

190. Parlar, A.; Arslan, S.O.; Doğan, M.F.; Çam, S.A.; Yalçin, A.; Elibol, E.; Özer, M.K.; Üçkardeş, F.; Kara, H. The exogenous administration of CB2 specific agonist, GW405833, inhibits inflammation by reducing cytokine production and oxidative stress. Exp. Ther. Med. 2018, 16, 4900-4908. [CrossRef]

191. Gonçalves, E.D.; Dutra, R.C. Cannabinoid receptors as therapeutic targets for autoimmune diseases: Where do we stand? Drug Discov. Today 2019, 24, 1845-1853. [CrossRef]

192. Turcotte, C.; Blanchet, M.R.; Laviolette, M.; Flamand, N. The CB 2 receptor and its role as a regulator of inflammation. Cell. Mol. Life Sci. 2016, 73, 4449-4470. [CrossRef]

193. Vara, D.; Salazar, M.; Olea-Herrero, N.; Guzman, M.; Velasco, G.; Diaz-Laviada, I. Anti-tumoral action of cannabinoids on hepatocellular carcinoma: Role of AMPK-dependent activation of autophagy. Cell Death Differ. 2011, 18, 1099-1111. [CrossRef] [PubMed]

194. Steinberg, G.R.; Schertzer, J.D. AMPK promotes macrophage fatty acid oxidative metabolism to mitigate inflammation: Implications for diabetes and cardiovascular disease. Immunol. Cell Biol. 2014, 92, 340-345. [CrossRef] [PubMed]

195. van Niekerk, G.; Mabin, T.; Engelbrecht, A.M. Anti-inflammatory mechanisms of cannabinoids: An immunometabolic perspective. Inflammopharmacology 2019, 27, 39-46. [CrossRef] [PubMed]

196. Toguri, J.; Leishman, E.; Szczesniak, A.; Laprairie, R.; Oehler, O.; Straiker, A.; Kelly, M.; Bradshaw, H. Inflammation and CB2 signaling drive novel changes in the ocular lipidome and regulate immune cell activity in the eye. Prostaglandins Other Lipid Mediat. 2018, 139, 54-62. [CrossRef] [PubMed]

197. Espinosa-Riquer, Z.P.; Ibarra-Sánchez, A.; Vibhushan, S.; Bratti, M.; Charles, N.; Blank, U.; Rodríguez-Manzo, G.; González-Espinosa, C. TLR4 Receptor Induces 2-AG-Dependent Tolerance to Lipopolysaccharide and Trafficking of CB2 Receptor in Mast Cells. J. Immunol. 2019, 202, 2360-2371. [CrossRef]

198. Buisseret, B.; Alhouayek, M.; Guillemot-Legris, O.; Muccioli, G.G. Endocannabinoid and Prostanoid Crosstalk in Pain. Trends Mol. Med. 2019, 25, 882-896. [CrossRef]

199. Turcotte, C.; Chouinard, F.; Lefebvre, J.S.; Flamand, N. Regulation of inflammation by cannabinoids, the endocannabinoids 2-arachidonoyl-glycerol and arachidonoyl-ethanolamide, and their metabolites. J. Leukoc. Biol. 2015, 97, 1049-1070. [CrossRef]

200. Chiurchiù, V.; Leuti, A.; Maccarrone, M. Bioactive lipids and chronic inflammation: Managing the fire within. Front. Immunol. 2018, 9, 38. [CrossRef]

201. Ambrożewicz, E.; Wójcik, P.; Wroński, A.; Łuczaj, W.; Jastrząb, A.; Žarković, N.; Skrzydlewska, E. Pathophysiological Alterations of Redox Signaling and Endocannabinoid System in Granulocytes and Plasma of Psoriatic Patients. Cells 2018, 7, 159. [CrossRef]

202. Nam, G.; Jeong, S.K.; Park, B.M.; Lee, S.H.; Kim, H.J.; Hong, S.P.; Kim, B.; Kim, B.W. Selective cannabinoid receptor-1 agonists regulate mast cell activation in an oxazolone-induced atopic dermatitis model. Ann. Dermatol. 2016, 28, 22-29. [CrossRef] [PubMed]

203. Rahmani, M.R.; Shamsizadeh, A.; Moghadam-Ahmadi, A.; Bazmandegan, G.; Allahtavakoli, M. JZL184, as a monoacylglycerol lipase inhibitor, down-regulates inflammation in a cannabinoid pathway dependent manner. Biomed. Pharmacother. 2018, 103, 1720-1726. [CrossRef]

204. Chen, H.J.C.; Spiers, J.G.; Sernia, C.; Lavidis, N.A. Inhibition of fatty acid amide hydrolase by PF-3845 alleviates the nitrergic and proinflammatory response in rat hippocampus following acute stress. Int. J. Neuropsychopharmacol. 2018, 21, 786-795. [CrossRef] [PubMed] 
205. Tanaka, M.; Yagyu, K.; Sackett, S.; Zhang, Y. Anti-Inflammatory Effects by Pharmacological Inhibition or Knockdown of Fatty Acid Amide Hydrolase in BV2 Microglial Cells. Cells 2019, 8, 491. [CrossRef] [PubMed]

206. Kim, J.H. The Emerging Role of TRPV1 in Airway Inflammation. Allergy, Asthma Immunol. Res. 2018, 10, 187-188. [CrossRef] [PubMed]

207. Tsuji, F.; Aono, H. Role of transient receptor potential vanilloid 1 in inflammation and autoimmune diseases. Pharmaceuticals 2012, 5, 837-852. [CrossRef]

208. Cruz, S.L.; Sánchez-Miranda, E.; Castillo-Arellano, J.I.; Cervantes-Villagrana, R.D.; Ibarra-Sánchez, A.; González-Espinosa, C. Anandamide inhibits FceRI-dependent degranulation and cytokine synthesis in mast cells through CB2 and GPR55 receptor activation. Possible involvement of CB2-GPR55 heteromers. Int. Immunopharmacol. 2018, 64, 298-307. [CrossRef]

209. Motwani, M.P.; Bennett, F.; Norris, P.C.; Maini, A.A.; George, M.J.; Newson, J.; Henderson, A.; Hobbs, A.J.; Tepper, M.; White, B.; et al. Potent anti-inflammatory and pro-resolving effects of anabasum in a human model of self-resolving acute inflammation. Clin. Pharmacol. Ther. 2018, 104, 675-686. [CrossRef]

210. García-Martín, A.; Garrido-Rodríguez, M.; Navarrete, C.; Caprioglio, D.; Palomares, B.; DeMesa, J.; Rollland, A.; Appendino, G.; Muñoz, E. Cannabinoid derivatives acting as dual PPAR $\gamma / \mathrm{CB} 2$ agonists as therapeutic agents for systemic sclerosis. Biochem. Pharmacol. 2019, 163, 321-334. [CrossRef]

211. del Rio, C.; Cantarero, I.; Palomares, B.; Gómez-Cañas, M.; Fernández-Ruiz, J.; Pavicic, C.; García-Martín, A.; Luz Bellido, M.; Ortega-Castro, R.; Pérez-Sánchez, C.; et al. VCE-004.3, a cannabidiol aminoquinone derivative, prevents bleomycin-induced skin fibrosis and inflammation through PPAR $\gamma$-and CB2 receptor-dependent pathways. Br. J. Pharmacol. 2018, 175, 3813-3831. [CrossRef]

212. Cinar, R.; Gochuico, B.R.; Iyer, M.R.; Jourdan, T.; Yokoyama, T.; Park, J.K.; Coffey, N.J.; Pri-Chen, H.; Szanda, G.; Liu, Z.; et al. Cannabinoid CB1 receptor overactivity contributes to the pathogenesis of idiopathic pulmonary fibrosis. JCI Insight 2017, 2, 92281. [CrossRef] [PubMed]

213. Zhou, L.; Zhou, S.; Yang, P.; Tian, Y.; Feng, Z.; Xie, X.Q.; Liu, Y. Targeted inhibition of the type 2 cannabinoid receptor is a novel approach to reduce renal fibrosis. Kidney Int. 2018, 94, 756-772. [CrossRef] [PubMed]

214. Rossi, F.; Punzo, F.; Umano, G.R.; Argenziano, M.; Miraglia Del Giudice, E. Role of cannabinoids in obesity. Int. J. Mol. Sci. 2018, 19, 2690. [CrossRef] [PubMed]

215. de Azua, I.R.; Lutz, B. Multiple endocannabinoid-mediated mechanisms in the regulation of energy homeostasis in brain and peripheral tissues. Cell. Mol. Life Sci. 2019, 76, 1341-1363. [CrossRef]

216. Ogden, S.B.; Malamas, M.S.; Makriyannis, A.; Eckel, L.A. The novel cannabinoid 1 receptor agonist AM11101 increases food intake in female rats. Br. J. Pharmacol. 2019, 176, 3972-3982. [CrossRef]

217. Scheen, A.J.; Finer, N.; Hollander, P.; Jensen, M.D.; Van Gaal, L.F.; RIO-Diabetes Study Group. Efficacy and tolerability of rimonabant in overweight or obese patients with type 2 diabetes: A randomised controlled study. Lancet 2006, 368, 1660-1672. [CrossRef]

218. Chorvat, R.J. Peripherally restricted CB1 receptor blockers. Bioorganic Med. Chem. Lett. 2013, 23, 4751-4760. [CrossRef]

219. Han, J.H.; Shin, H.; Park, J.Y.; Rho, J.G.; Son, D.H.; Kim, K.W.; Seong, J.K.; Yoon, S.H.; Kim, W. A novel peripheral cannabinoid 1 receptor antagonist, AJ5012, improves metabolic outcomes and suppresses adipose tissue inflammation in obese mice. FASEB J. 2019, 33, 4314-4326. [CrossRef]

220. Han, J.H.; Shin, H.; Rho, J.G.; Kim, J.E.; Son, D.H.; Yoon, J.; Lee, Y.J.; Park, J.H.; Song, B.J.; Choi, C.S.; et al. Peripheral cannabinoid 1 receptor blockade mitigates adipose tissue inflammation via NLRP3 inflammasome in mouse models of obesity. Diabetes, Obes. Metab. 2018, 20, 2179-2189. [CrossRef]

221. Seltzman, H.H.; Maitra, R.; Bortoff, K.; Henson, J.; Reggio, P.H.; Wesley, D.; Tam, J. Metabolic profiling of CB1 neutral antagonists. Methods Enzymol. 2017, 593, 199-215.

222. Horswill, J.; Bali, U.; Shaaban, S.; Keily, J.; Jeevaratnam, P.; Babbs, A.; Reynet, C.; Wong Kai In, P. PSNCBAM-1, a novel allosteric antagonist at cannabinoid CB1 receptors with hypophagic effects in rats. Br. J. Pharmacol. 2007, 152, 805-814. [CrossRef] [PubMed]

223. Ding, Y.; Qiu, Y.; Jing, L.; Thorn, D.A.; Zhang, Y.; Li, J.X. Behavioral effects of the cannabinoid CB1 receptor allosteric modulator ORG27569 in rats. Pharmacol. Res. Perspect. 2014, 2, e00069. [CrossRef] [PubMed]

224. Lipina, C.; Walsh, S.K.; Mitchell, S.E.; Speakman, J.R.; Wainwright, C.L.; Hundal, H.S. GPR55 deficiency is associated with increased adiposity and impaired insulin signaling in peripheral metabolic tissues. FASEB J. 2019, 33, 1299-1312. [CrossRef] 
225. Simcocks, A.; Jenkin, K.; O’keefe, L.; Samuel, C.; Mathai, M.; McAinch, A.; Hryciw, D. Atypical cannabinoid ligands O-1602 and O-1918 administered chronically in diet-induced obesity. Endocr. Connect. 2019, 8, 203-216. [CrossRef]

226. Di Marzo, V. The endocannabinoid system in obesity and type 2 diabetes. Diabetologia 2008, 51, $1356-1367$. [CrossRef]

227. Gruden, G.; Barutta, F.; Kunos, G.; Pacher, P. Role of the endocannabinoid system in diabetes and diabetic complications. Br. J. Pharmacol. 2016, 173, 1116-1127. [CrossRef]

228. Grunewald, Z.I.; Lee, S.; Kirkland, R.; Ross, M.; Claire, B. Cannabinoid receptor type-1 partially mediates metabolic endotoxemia-induced inflammation and insulin resistance. Physiol. Behav. 2019, 199, 282-291. [CrossRef]

229. González-Mariscal, I.; Egan, J.M. Endocannabinoids in the Islets of Langerhans: The ugly, the bad, and the good facts. Am. J. Physiol.-Endocrinol. Metab. 2018, 315, E174-E179. [CrossRef]

230. Hinden, L.; Udi, S.; Drori, A.; Gammal, A.; Nemirovski, A.; Hadar, R.; Baraghithy, S.; Permyakova, A.; Geron, M.; Cohen, M.; et al. Modulation of renal GLUT2 by the cannabinoid-1 receptor: Implications for the treatment of diabetic nephropathy. J. Am. Soc. Nephrol. 2018, 29, 434-448. [CrossRef]

231. Hinden, L.; Tam, J. Do Endocannabinoids Regulate Glucose Reabsorption in the Kidney? Nephron 2019, 143, 24-27. [CrossRef]

232. Barutta, F.; Bellini, S.; Mastrocola, R.; Gambino, R.; Piscitelli, F.; di Marzo, V.; Corbetta, B.; Vemuri, V.; Makriyannis, A.; Annaratone, L.; et al. Reversal of albuminuria by combined AM6545 and perindopril therapy in experimental diabetic nephropathy. Br. J. Pharmacol. 2018, 175, 4371-4385. [CrossRef] [PubMed]

233. Tung, C.W.; Ho, C.; Hsu, Y.C.; Huang, S.C.; Shih, Y.H.; Lin, C.L. MicroRNA-29a attenuates diabetic glomerular injury through modulating cannabinoid receptor 1 signaling. Molecules 2019, 24, 264. [CrossRef] [PubMed]

234. Kumawat, V.S.; Kaur, G. Therapeutic potential of cannabinoid receptor 2 in the treatment of diabetes mellitus and its complications. Eur. J. Pharmacol. 2019, 862, 172628. [CrossRef] [PubMed]

235. Wu, A.; Hu, P.; Lin, J.; Xia, W.; Zhang, R. Activating cannabinoid receptor 2 protects against diabetic cardiomyopathy through autophagy induction. Front. Pharmacol. 2018, 9, 1292. [CrossRef] [PubMed]

236. Vong, C.T.; Tseng, H.H.L.; Kwan, Y.W.; Lee, S.M.Y.; Hoi, M.P.M. Novel protective effect of O-1602 and abnormal cannabidiol, GPR55 agonists, on ER stress-induced apoptosis in pancreatic $\beta$-cells. Biomed. Pharmacother. 2019, 111, 1176-1186. [CrossRef] [PubMed]

237. Soga, T.; Ohishi, T.; Matsui, T.; Saito, T.; Matsumoto, M.; Takasaki, J.; Matsumoto, S.i.; Kamohara, M.; Hiyama, H.; Yoshida, S.; et al. Lysophosphatidylcholine enhances glucose-dependent insulin secretion via an orphan G-protein-coupled receptor. Biochem. Biophys. Res. Commun. 2005, 326, 744-751. [CrossRef]

238. Chu, Z.L.; Carroll, C.; Alfonso, J.; Gutierrez, V.; He, H.; Lucman, A.; Pedraza, M.; Mondala, H.; Gao, H.; Bagnol, D.; et al. A role for intestinal endocrine cell-expressed g protein-coupled receptor 119 in glycemic control by enhancing glucagon-like Peptide-1 and glucose-dependent insulinotropic Peptide release. Endocrinology 2008, 149, 2038-2047. [CrossRef]

239. Gendaszewska-Darmach, E.; Drzazga, A.; Koziołkiewicz, M. Targeting GPCRs Activated by Fatty Acid-Derived Lipids in Type 2 Diabetes. Trends Mol. Med. 2019, 25, 915-929. [CrossRef]

240. Huan, Y.; Jiang, Q.; Li, G.; Bai, G.; Zhou, T.; Liu, S.; Li, C.; Liu, Q.; Sun, S.; Yang, M.; et al. The dual DPP4 inhibitor and GPR119 agonist HBK001 regulates glycemic control and beta cell function ex and in vivo. Sci. Rep. 2017, 7, 4351. [CrossRef]

241. Bazwinsky-Wutschke, I.; Zipprich, A.; Dehghani, F. Endocannabinoid System in Hepatic Glucose Metabolism, Fatty Liver Disease, and Cirrhosis. Int. J. Mol. Sci. 2019, 20, 2516. [CrossRef]

242. Jorgačević, B.; Vučević, D.; Vesković, M.; Mladenović, D.; Vukićević, D.; Vukićević, R.J.; Todorović, V.; Radosavljević, T. The effect of cannabinoid receptor 1 blockade on adipokine and proinflammatory cytokine concentration in adipose and hepatic tissue in mice with nonalcoholic fatty liver disease. Can. J. Physiol. Pharmacol. 2019, 97, 120-129. [CrossRef] [PubMed]

243. Chang, E.; Kim, D.H.; Yang, H.; Lee, D.H.; Bae, S.H.; Park, C.Y. CB1 receptor blockade ameliorates hepatic fat infiltration and inflammation and increases Nrf2-AMPK pathway in a rat model of severely uncontrolled diabetes. PLoS ONE 2018, 13, e0206152. [CrossRef] [PubMed] 
244. Bahirat, U.A.; Shenoy, R.R.; Goel, R.N.; Nemmani, K.V. APD668, a G protein-coupled receptor 119 agonist improves fat tolerance and attenuates fatty liver in high-trans fat diet induced steatohepatitis model in C57BL/ 6 mice. Eur. J. Pharmacol. 2017, 801, 35-45. [CrossRef] [PubMed]

245. Sánchez, A.A.; Awan, A.; Karl, M.; Santini, A. Cardiovascular effects of cannabis (marijuana): A timely update. Phytother. Res. PTR 2019, 33, 1592-1594. [CrossRef] [PubMed]

246. Sierra, S.; Luquin, N.; Navarro-Otano, J. The endocannabinoid system in cardiovascular function: Novel insights and clinical implications. Clin. Auton. Res. 2018, 28, 35-52. [CrossRef]

247. Malinowska, B.; Toczek, M.; Pędzińska-Betiuk, A.; Schlicker, E. Cannabinoids in arterial, pulmonary and portal hypertension-mechanisms of action and potential therapeutic significance. Br. J. Pharmacol. 2019, 176, 1395-1411. [CrossRef]

248. Bermudez, A.M.; Visina, J.M.; Walker, L.A. Differential effects of cannabinoid receptor stimulation in smooth muscle. FASEB J. 2017, 31, 690-694.

249. Giménez, V.M.M.; Díaz-Rodríguez, P.; Sanz, R.L.; Vivero-Lopez, M.; Concheiro, A.; Diez, E.; Prado, N.; Kassuha, D.E.; Alvarez-Lorenzo, C.; Manucha, W. Anandamide-nanoformulation obtained by electrospraying for cardiovascular therapy. Int. J. Pharm. 2019, 566, 1-10. [CrossRef]

250. Ahmad, A.; Dempsey, S.K.; Daneva, Z.; Li, N.; Poklis, J.L.; Li, P.L.; Ritter, J.K. Modulation of mean arterial pressure and diuresis by renomedullary infusion of a selective inhibitor of fatty acid amide hydrolase. Am. J. Physiol.-Ren. Physiol. 2018, 315, F967-F976. [CrossRef]

251. Toczek, M.; Baranowska-Kuczko, M.; Grzęda, E.; Pędzińska-Betiuk, A.; Weresa, J.; Malinowska, B. Age-specific influences of chronic administration of the fatty acid amide hydrolase inhibitor URB597 on cardiovascular parameters and organ hypertrophy in DOCA-salt hypertensive rats. Pharmacol. Rep. 2016, 68, 363-369. [CrossRef]

252. Biernacki, M.; Ambrożewicz, E.; Geggotek, A.; Toczek, M.; Bielawska, K.; Skrzydlewska, E. Redox system and phospholipid metabolism in the kidney of hypertensive rats after FAAH inhibitor URB597 administration. Redox Biol. 2018, 15, 41-50. [CrossRef] [PubMed]

253. Lagatta, D.C.; Kuntze, L.B.; Ferreira-Junior, N.C.; Resstel, L.B. Medial prefrontal cortex TRPV1 and CB1 receptors modulate cardiac baroreflex activity by regulating the NMDA receptor/nitric oxide pathway. Pflügers Arch.-Eur. J. Physiol. 2018, 470, 1521-1542. [CrossRef] [PubMed]

254. Song, S.; Ayon, R.J.; Yamamura, A.; Yamamura, H.; Dash, S.; Babicheva, A.; Tang, H.; Sun, X.; Cordery, A.G.; Khalpey, Z.; et al. Capsaicin-induced Ca2+ signaling is enhanced via upregulated TRPV1 channels in pulmonary artery smooth muscle cells from patients with idiopathic PAH. Am. J. Physiol.-Lung Cell. Mol. Physiol. 2017, 312, L309-L325. [CrossRef] [PubMed]

255. Guillamat-Prats, R.; Rami, M.; Herzig, S.; Steffens, S. Endocannabinoid signaling in atherosclerosis and related metabolic complications. Thromb. Haemost. 2019, 119, 567-575.

256. Rajesh, M.; Mukhopadhyay, P.; Haskó, G.; Liaudet, L.; Mackie, K.; Pacher, P. Cannabinoid-1 receptor activation induces reactive oxygen species-dependent and-independent mitogen-activated protein kinase activation and cell death in human coronary artery endothelial cells. Br. J. Pharmacol. 2010, 160, 688-700. [CrossRef]

257. Sugamura, K.; Sugiyama, S.; Fujiwara, Y.; Matsubara, J.; Akiyama, E.; Maeda, H.; Ohba, K.; Matsuzawa, Y.; Konishi, M.; Nozaki, T.; et al. Cannabinoid 1 receptor blockade reduces atherosclerosis with enhances reverse cholesterol transport. J. Atheroscler. Thromb. 2010, 17, 141-147. [CrossRef]

258. Prats, R.G.; Rami, M.; Ring, L.; Rinne, P.; Lauer, E.; Lenglet, S.; Thomas, A.; Pagano, S.; Vuilleumier, N.; Cravatt, B.F.; et al. Deficiency of monoacylglycerol lipase enhances IgM plasma levels and limits atherogenesis in a CB2-dependent manner. Thromb. Haemost. 2019, 119, 348-351.

259. Rinne, P.; Guillamat-Prats, R.; Rami, M.; Bindila, L.; Ring, L.; Lyytikäinen, L.P.; Raitoharju, E.; Oksala, N.; Lehtimäki, T.; Weber, C.; et al. Palmitoylethanolamide promotes a proresolving macrophage phenotype and attenuates atherosclerotic plaque formation. Arterioscler. Thromb. Vasc. Biol. 2018, 38, 2562-2575. [CrossRef]

260. Montecucco, F.; Bondarenko, A.I.; Lenglet, S.; Burger, F.; Piscitelli, F.; Carbone, F.; Roth, A.; Liberale, L.; Dallegri, F.; Brandt, K.J.; et al. Treatment with the GPR55 antagonist CID16020046 increases neutrophil activation in mouse atherogenesis. Thromb. Haemost. 2016, 116, 987-997.

261. Schloss, M.J.; Horckmans, M.; Guillamat-Prats, R.; Hering, D.; Lauer, E.; Lenglet, S.; Weber, C.; Thomas, A.; Steffens, S. 2-Arachidonoylglycerol mobilizes myeloid cells and worsens heart function after acute myocardial infarction. Cardiovasc. Res. 2019, 115, 602-613. [CrossRef] 
262. Duerr, G.D.; Heinemann, J.C.; Kley, J.; Eichhorn, L.; Frede, S.; Weisheit, C.; Wehner, S.; Bindila, L.; Lutz, B.; Zimmer, A.; et al. Myocardial maladaptation to pressure overload in CB2 receptor-deficient mice. J. Mol. Cell. Cardiol. 2019, 133, 86-98. [CrossRef]

263. Hai, K.; Chen, G.; Gou, X.; Jang, H.; Gong, D.; Cheng, Y.; Gong, C.; Li, X.; Liu, Y.; Li, H.; et al. Monoacylglycerol Lipase Inactivation by Using URB602 Mitigates Myocardial Damage in a Rat Model of Cardiac Arrest. Crit. Care Med. 2019, 47, e144-e151. [CrossRef]

264. Vago, R.; Bettiga, A.; Salonia, A.; Ciuffreda, P.; Ottria, R. Development of new inhibitors for $\mathrm{N}$-acylethanolamine-hydrolyzing acid amidase as promising tool against bladder cancer. Bioorganic Med. Chem. 2017, 25, 1242-1249. [CrossRef] [PubMed]

265. Coke, C.J.; Scarlett, K.A.; Chetram, M.A.; Jones, K.J.; Sandifer, B.J.; Davis, A.S.; Marcus, A.I.; Hinton, C.V. Simultaneous activation of induced heterodimerization between CXCR4 chemokine receptor and cannabinoid receptor 2 (CB2) reveals a mechanism for regulation of tumor progression. J. Biol. Chem. 2016, 291, 9991-10005. [CrossRef] [PubMed]

266. Moreno, E.; Cavic, M.; Krivokuca, A.; Casadó, V.; Canela Campos, E.I. The endocannabinoid system as a target in cancer diseases: Are we there yet? Front. Pharmacol. 2019, 10, 339. [CrossRef] [PubMed]

267. Morales, P.; Jagerovic, N. Antitumor cannabinoid chemotypes: Structural insights. Front. Pharmacol. 2019, 10, 621. [CrossRef] [PubMed]

268. Capozzi, A.; Mattei, V.; Martellucci, S.; Manganelli, V.; Saccomanni, G.; Garofalo, T.; Sorice, M.; Manera, C.; Misasi, R. Anti-Proliferative Properties and Proapoptotic Function of New CB2 Selective Cannabinoid Receptor Agonist in Jurkat Leukemia Cells. Int. J. Mol. Sci. 2018, 19, 1958. [CrossRef]

269. Khan, M.I.; Sobocińska, A.A.; Brodaczewska, K.K.; Zielniok, K.; Gajewska, M.; Kieda, C.; Czarnecka, A.M.; Szczylik, C. Involvement of the CB 2 cannabinoid receptor in cell growth inhibition and G0/G1 cell cycle arrest via the cannabinoid agonist WIN 55,212-2 in renal cell carcinoma. BMC Cancer 2018, 18, 583. [CrossRef]

270. Youssif, B.G.; Mohamed, A.M.; Osman, E.E.A.; Abou-Ghadir, O.F.; Elnaggar, D.H.; Abdelrahman, M.H.; Treamblu, L.; Gomaa, H.A. 5-Chlorobenzofuran-2-carboxamides: From allosteric CB1 modulators to potential apoptotic antitumor agents. Eur. J. Med. Chem. 2019, 177, 1-11. [CrossRef]

271. Carpi, S.; Fogli, S.; Polini, B.; Montagnani, V.; Podestà, A.; Breschi, M.C.; Romanini, A.; Stecca, B.; Nieri, P. Tumor-promoting effects of cannabinoid receptor type 1 in human melanoma cells. Toxicol. Vitr. 2017, 40, 272-279. [CrossRef]

272. Yang, J.; Tian, Y.; Zheng, R.; Li, L.; Qiu, F. Endocannabinoid system and the expression of endogenous ceramides in human hepatocellular carcinoma. Oncol. Lett. 2019, 18, 1530-1538. [CrossRef] [PubMed]

273. Winkler, K.; Ramer, R.; Dithmer, S.; Ivanov, I.; Merkord, J.; Hinz, B. Fatty acid amide hydrolase inhibitors confer anti-invasive and antimetastatic effects on lung cancer cells. Oncotarget 2016, 7, 15047-15064. [CrossRef] [PubMed]

274. Soliman, E.; Van Dross, R. Anandamide-induced endoplasmic reticulum stress and apoptosis are mediated by oxidative stress in non-melanoma skin cancer: Receptor-independent endocannabinoid signaling. Mol. Carcinog. 2016, 55, 1807-1821. [CrossRef] [PubMed]

275. Fonseca, B.M.; Correia-da Silva, G.; Teixeira, N. Cannabinoid-induced cell death in endometrial cancer cells: involvement of TRPV1 receptors in apoptosis. J. Physiol. Biochem. 2018, 74, 261-272. [CrossRef] [PubMed]

276. Qiu, C.; Yang, L.; Wang, B.; Cui, L.; Li, C.; Zhuo, Y.; Zhang, L.; Zhang, S.; Zhang, Q.; Wang, X. The role of 2-arachidonoylglycerol in the regulation of the tumor-immune microenvironment in murine models of pancreatic cancer. Biomed. Pharmacother. 2019, 115, 108952. [CrossRef] [PubMed]

277. Baba, Y.; Funakoshi, T.; Mori, M.; Emoto, K.; Masugi, Y.; Ekmekcioglu, S.; Amagai, M.; Tanese, K. Expression of monoacylglycerol lipase as a marker of tumour invasion and progression in malignant melanoma. J. Eur. Acad. Dermatol. Venereol. 2017, 31, 2038-2045. [CrossRef]

278. Hu, W.R.; Lian, Y.F.; Peng, L.X.; Lei, J.J.; Deng, C.C.; Xu, M.; Feng, Q.S.; Chen, L.Z.; Bei, J.X.; Zeng, Y.X. Monoacylglycerol lipase promotes metastases in nasopharyngeal carcinoma. Int. J. Clin. Exp. Pathol. 2014, 7, 3704-3713.

279. Li, X.; Gao, S.; Li, W.; Liu, Z.; Shi, Z.; Qiu, C.; Jiang, J. Effect of monoacylglycerol lipase on the tumor growth in endometrial cancer. J. Obstet. Gynaecol. Res. 2019, 45, 2043-2054. [CrossRef]

280. Mulvihill, M.M.; Nomura, D.K. Therapeutic potential of monoacylglycerol lipase inhibitors. Life Sci. 2013, 92, 492-497. [CrossRef] 
281. Granchi, C.; Lapillo, M.; Glasmacher, S.; Bononi, G.; Licari, C.; Poli, G.; El Boustani, M.; Caligiuri, I.; Rizzolio, F.; Gertsch, J.; et al. Optimization of a benzoylpiperidine class identifies a highly potent and selective reversible monoacylglycerol lipase (MAGL) inhibitor. J. Med. Chem. 2019, 62, 1932-1958. [CrossRef]

282. Ma, M.; Bai, J.; Ling, Y.; Chang, W.; Xie, G.; Li, R.; Wang, G.; Tao, K. Monoacylglycerol lipase inhibitor JZL184 regulates apoptosis and migration of colorectal cancer cells. Mol. Med. Rep. 2016, 13, 2850-2856. [CrossRef] [PubMed]

283. Marino, S.; de Ridder, D.; Bishop, R.T.; Renema, N.; Ponzetti, M.; Sophocleous, A.; Capulli, M.; Aljeffery, A.; Carrasco, G.; Gens, M.D.; et al. Paradoxical effects of JZL184, an inhibitor of monoacylglycerol lipase, on bone remodelling in healthy and cancer-bearing mice. EBioMedicine 2019, 44, 452-466. [CrossRef] [PubMed]

284. Pagano, E.; Borrelli, F.; Orlando, P.; Romano, B.; Monti, M.; Morbidelli, L.; Aviello, G.; Imperatore, R.; Capasso, R.; Piscitelli, F.; et al. Pharmacological inhibition of MAGL attenuates experimental colon carcinogenesis. Pharmacol. Res. 2017, 119, 227-236. [CrossRef] [PubMed]

285. Ramer, R.; Schwarz, R.; Hinz, B. Modulation of the Endocannabinoid System as a Potential Anticancer Strategy. Front. Pharmacol. 2019, 10, 430. [CrossRef]

286. Brunetti, L.; Loiodice, F.; Piemontese, L.; Tortorella, P.; Laghezza, A. New Approaches to Cancer Therapy: Combining Fatty Acid Amide Hydrolase (FAAH) Inhibition with Peroxisome Proliferator-Activated Receptors (PPARs) Activation: Miniperspective. J. Med. Chem. 2019, 62, 10995-11003. [CrossRef]

287. Chicca, A.; Arena, C.; Bertini, S.; Gado, F.; Ciaglia, E.; Abate, M.; Digiacomo, M.; Lapillo, M.; Poli, G.; Bifulco, M.; et al. Polypharmacological profile of 1, 2-dihydro-2-oxo-pyridine-3-carboxamides in the endocannabinoid system. Eur. J. Med. Chem. 2018, 154, 155-171. [CrossRef]

288. Kargl, J.; Andersen, L.; Hasenöhrl, C.; Feuersinger, D.; Stančić, A.; Fauland, A.; Magnes, C.; El-Heliebi, A.; Lax, S.; Uranitsch, S.; et al. GPR55 promotes migration and adhesion of colon cancer cells indicating a role in metastasis. Br. J. Pharmacol. 2016, 173, 142-154. [CrossRef]

289. Hasenoehrl, C.; Feuersinger, D.; Sturm, E.M.; Bärnthaler, T.; Heitzer, E.; Graf, R.; Grill, M.; Pichler, M.; Beck, S.; Butcher, L.; et al. G protein-coupled receptor GPR55 promotes colorectal cancer and has opposing effects to cannabinoid receptor 1. Int. J. Cancer 2018, 142, 121-132. [CrossRef]

290. Zhou, X.1.; Guo, X.; Song, Y.p.; Zhu, C.y.; Zou, W. The LPI/GPR55 axis enhances human breast cancer cell migration via HBXIP and p-MLC signaling. Acta Pharmacol. Sin. 2018, 39, 459-471. [CrossRef]

291. Andradas, C.; Blasco-Benito, S.; Castillo-Lluva, S.; Dillenburg-Pilla, P.; Diez-Alarcia, R.; Juanes-García, A.; García-Taboada, E.; Hernando-Llorente, R.; Soriano, J.; Hamann, S.; et al. Activation of the orphan receptor GPR55 by lysophosphatidylinositol promotes metastasis in triple-negative breast cancer. Oncotarget 2016, 7, 47565-47575. [CrossRef]

292. Brown, A.J.; Castellano-Pellicena, I.; Haslam, C.P.; Nichols, P.L.; Dowell, S.J. Structure-Activity Relationship of the GPR55 Antagonist, CID16020046. Pharmacology 2018, 102, 324-331. [CrossRef] [PubMed]

293. Hinz, B.; Ramer, R. Anti-tumour actions of cannabinoids. Br. J. Pharmacol. 2019, 176, 1384-1394. [CrossRef] [PubMed]

294. Zhang, J.; Zhang, S.; Liu, Y.; Su, M.; Ling, X.; Liu, F.; Ge, Y.; Bai, M. Combined CB2 receptor agonist and photodynamic therapy synergistically inhibit tumor growth in triple negative breast cancer. Photodiagnosis Photodyn. Ther. 2018, 24, 185-191. [CrossRef] [PubMed]

295. Chatkin, J.; Zani-Silva, L.; Ferreira, I.; Zamel, N. Cannabis-associated asthma and allergies. Clin. Rev. Allergy Immunol. 2019, 56, 196-206. [CrossRef]

296. Ashton, J.C.; Hancox, R.J. The Case for Cannabinoid CB1 Receptors as a Target for Bronchodilator Therapy for $\beta$-agonist Resistant Asthma. Curr. Drug Targets 2018, 19, 1344-1349. [CrossRef] [PubMed]

297. Bozkurt, T.E.; Kaya, Y.; Durlu-Kandilci, N.T.; Onder, S.; Sahin-Erdemli, I. The effect of cannabinoids on dinitrofluorobenzene-induced experimental asthma in mice. Respir. Physiol. Neurobiol. 2016, 231, 7-13. [CrossRef]

298. Vuolo, F.; Abreu, S.C.; Michels, M.; Xisto, D.G.; Blanco, N.G.; Hallak, J.E.; Zuardi, A.W.; Crippa, J.A.; Reis, C.; Bahl, M.; et al. Cannabidiol reduces airway inflammation and fibrosis in experimental allergic asthma. Eur. J. Pharmacol. 2019, 843, 251-259. [CrossRef]

299. Park, J.; Yokoyama, T.; Jourdan, T.; Malicdan, M.; Coffey, N.; Gahl, W.; Kunos, G.; Cinar, R. Cannabinoid Receptor 1 (cb1r) Activation Induces Alveolar Macrophages To Acquire A Proinflammatory In addition, Profibrotic Phenotype In Pulmonary Fibrosis. In American Thoracic Society International Conference Abstracts; American Thoracic Society: Washington, DC, USA, 2017; p. A7065. 
300. Coffey, N.; Park, J.; Jourdan, T.; Yokoyama, T.; Gahl, W.; Malicdan, M.; Cinar, R.; Kunos, G. Deletion of Cannabinoid Receptor 1 (CB1R) in Myeloid Cells Prevents the Progression of Bleomycin-Induced Pulmonary Fibrosis in Mice. In American Thoracic Society International Conference Abstracts; American Thoracic Society: San Diego, CA, USA, 2018; p. A1051.

301. Cinar, R.; Yokoyama, T.; Coffey, N.; Park, J.; Iyer, M.; Gochuico, B.; Gahl, W.; Malicdan, M.; Kunos, G. The Endocannabinoid/CB1R System Is Overactive in Bleomycin-Induced Pulmonary Fibrosis in Pale Ear (HPS1) Mice. In American Thoracic Society International Conference Abstracts; American Thoracic Society: San Diego, CA, USA, 2018; p. A5757.

302. Wawryk-Gawda, E.; Chłapek, K.; Zarobkiewicz, M.K.; Lis-Sochocka, M.; Chylińska-Wrzos, P.; Boguszewska-Czubara, A.; Sławiński, M.A.; Franczak, A.; Jodłowska-Jędrych, B.; Biała, G. CB2R agonist prevents nicotine induced lung fibrosis. Exp. Lung Res. 2018, 44, 344-351. [CrossRef]

303. Pesce, M.; D'Alessandro, A.; Borrelli, O.; Gigli, S.; Seguella, L.; Cuomo, R.; Esposito, G.; Sarnelli, G. Endocannabinoid-related compounds in gastrointestinal diseases. J. Cell. Mol. Med. 2018, 22, 706-715. [CrossRef]

304. Grill, M.; Högenauer, C.; Blesl, A.; Haybaeck, J.; Golob-Schwarzl, N.; Ferreirós, N.; Thomas, D.; Gurke, R.; Trötzmüller, M.; Köfeler, H.C.; et al. Members of the endocannabinoid system are distinctly regulated in inflammatory bowel disease and colorectal cancer. Sci. Rep. 2019, 9, 2358. [CrossRef]

305. Ambrose, T.; Simmons, A. Cannabis, cannabinoids, and the endocannabinoid system-is there therapeutic potential for inflammatory bowel disease? J. Crohn's Colitis 2019, 13, 525-535. [CrossRef] [PubMed]

306. Salaga, M.; Binienda, A.; Tichkule, R.B.; Thakur, G.A.; Makriyannis, A.; Storr, M.; Fichna, J. The novel peripherally active cannabinoid type 1 and serotonin type 3 receptor agonist AM9405 inhibits gastrointestinal motility and reduces abdominal pain in mouse models mimicking irritable bowel syndrome. Eur. J. Pharmacol. 2018, 836, 34-43. [CrossRef] [PubMed]

307. Pellesi, L.; Verga, M.C.; De Maria, N.; Villa, E.; Pini, L.A.; Guerzoni, S. Nabilone administration in refractory chronic diarrhea: A case series. BMC Gastroenterol. 2019, 19, 105. [CrossRef] [PubMed]

308. Sharkey, K.A.; Darmani, N.A.; Parker, L.A. Regulation of nausea and vomiting by cannabinoids and the endocannabinoid system. Eur. J. Pharmacol. 2014, 722, 134-146. [CrossRef]

309. May, M.B.; Glode, A.E. Dronabinol for chemotherapy-induced nausea and vomiting unresponsive to antiemetics. Cancer Manag. Res. 2016, 8, 49-55.

310. Darmani, N.A.; Chebolu, S.; Zhong, W.; Trinh, C.; McClanahan, B.; Brar, R.S. Additive antiemetic efficacy of low-doses of the cannabinoid CB1/2 receptor agonist $\triangle 9$-THC with ultralow-doses of the vanilloid TRPV1 receptor agonist resiniferatoxin in the least shrew (Cryptotis parva). Eur. J. Pharmacol. 2014, 722, 147-155. [CrossRef]

311. Jiang, H.; Wu, Y.; Valverde, P.; Murray, D.; Tang, J.; Yao, Q.; Han, Q.; Zhang, J.; Zhang, L.; Sui, L.; et al. Central adiponectin induces trabecular bone mass partly through epigenetic downregulation of cannabinoid receptor CB1. J. Cell. Physiol. 2019, 234, 7062-7069. [CrossRef]

312. Samir, S.; Malek, H. Effect of cannabinoid receptors 1 modulation on osteoporosis in a rat model of different ages. J. Physiol. Pharmacol. 2014, 65, 687-694.

313. Smoum, R.; Baraghithy, S.; Chourasia, M.; Breuer, A.; Mussai, N.; Attar-Namdar, M.; Kogan, N.M.; Raphael, B.; Bolognini, D.; Cascio, M.G.; et al. CB2 cannabinoid receptor agonist enantiomers HU-433 and HU-308: An inverse relationship between binding affinity and biological potency. Proc. Natl. Acad. Sci. USA 2015, 112, 8774-8779. [CrossRef]

314. More, K.N.; Lee, Y.J.; Kim, K.J.; Suh, Y.G.; Son, Y.J.; Chang, D.J. Effect of TRPV1 Antagonist SC0030, a Potent Painkiller, on RANKL-mediated Osteoclast Differentiation Involved in Bone Resorption. Bull. Korean Chem. Soc. 2020. [CrossRef]

315. Walker, O.S.; Holloway, A.C.; Raha, S. The role of the endocannabinoid system in female reproductive tissues. J. Ovarian Res. 2019, 12, 3. [CrossRef] [PubMed]

316. Cui, N.; Feng, X.; Zhao, Z.; Zhang, J.; Xu, Y.; Wang, L.; Hao, G. Restored plasma anandamide and endometrial expression of fatty acid amide hydrolase in women with polycystic ovary syndrome by the combination use of Diane-35 and metformin. Clin. Ther. 2017, 39, 751-758. [CrossRef] [PubMed]

317. Shen, X.; Duan, H.; Wang, S.; Gan, L.; Xu, Q.; Li, J.J. Decreased Expression of Cannabinoid Receptors in the Eutopic and Ectopic Endometrium of Patients with Adenomyosis. BioMed Res. Int. 2019, 2019, 5468954. [CrossRef] [PubMed] 
318. Clemenza, S.; Sorbi, F.; Noci, I.; Capezzuoli, T.; Turrini, I.; Carriero, C.; Buffi, N.; Fambrini, M.; Petraglia, F. From pathogenesis to clinical practice: Emerging medical treatments for endometriosis. Best Pract. Res. Clin. Obstet. Gynaecol. 2018, 51, 92-101. [CrossRef]

319. Gratzke, C.; Christ, G.J.; Stief, C.G.; Andersson, K.E.; Hedlund, P. Localization and function of cannabinoid receptors in the corpus cavernosum: Basis for modulation of nitric oxide synthase nerve activity. Eur. Urol. 2010, 57, 342-348. [CrossRef]

320. Shamloul, R.; Bella, A.J. Impact of cannabis use on male sexual health. J. Sex. Med. 2011, 8, 971-975. [CrossRef]

321. Castelli, M.; Piras, A.; Melis, T.; Succu, S.; Sanna, F.; Melis, M.; Collu, S.; Ennas, M.G.; Diaz, G.; Mackie, K.; et al. Cannabinoid CB1 receptors in the paraventricular nucleus and central control of penile erection: Immunocytochemistry, autoradiography and behavioral studies. Neuroscience 2007, 147, 197-206. [CrossRef]

322. Milando, R.; Friedman, A. Cannabinoids: Potential Role in Inflammatory and Neoplastic Skin Diseases. Am. J. Clin. Dermatol. 2019, 20, 167-180. [CrossRef]

323. Tóth, K.F.; Ádám, D.; Bíró, T.; Oláh, A. Cannabinoid Signaling in the Skin: Therapeutic Potential of the “C(ut)annabinoid" System. Molecules 2019, 24, 918. [CrossRef]

324. Zákány, N.; Oláh, A.; Markovics, A.; Takács, E.; Aranyász, A.; Nicolussi, S.; Piscitelli, F.; Allarà, M.; Pór, Á.; Kovács, I.; et al. Endocannabinoid Tone Regulates Human Sebocyte Biology. J. Investig. Dermatol. 2018, 138, 1699-1706. [CrossRef]

325. Iannotti, F.A.; Pagano, E.; Guardiola, O.; Adinolfi, S.; Saccone, V.; Consalvi, S.; Piscitelli, F.; Gazzerro, E.; Busetto, G.; Carrella, D.; et al. Genetic and pharmacological regulation of the endocannabinoid CB1 receptor in Duchenne muscular dystrophy. Nat. Commun. 2018, 9, 3950. [CrossRef] [PubMed]

326. Iannotti, F.A. Pharmacological Actions and Potential Therapeutic Use of Cannabinoids in Duchenne's Muscular Dystrophy. In Muscular Dystrophies; Sakuma, K., Ed.; IntechOpen: London, UK, 2019.

327. Beal, J.E.; Olson, R.; Laubenstein, L.; Morales, J.O.; Bellman, P.; Yangco, B.; Lefkowitz, L.; Plasse, T.F.; Shepard, K.V. Dronabinol as a treatment for anorexia associated with weight loss in patients with AIDS. J. Pain Symptom Manag. 1995, 10, 89-97. [CrossRef]

328. AbbVie. MARINOL (dronabinol) [drug label]. US Food and Drug Administration. Revised August 2017. Available online: https:/ / www.accessdata.fda.gov /drugsatfda_docs/label/2017/018651s029lbl.pdf (accessed on 18 February 2020).

329. Badowski, M.E.; Yanful, P.K. Dronabinol oral solution in the management of anorexia and weight loss in AIDS and cancer. Ther. Clin. Risk Manag. 2018, 14, 643-651. [CrossRef] [PubMed]

330. Valeant Pharmaceuticals International. Cesamet (nabilone) [drug label]. US Food and Drug Administration. Revised May 2006. Available online: https://www.accessdata.fda.gov/drugsatfda_docs/label/2006/ 018677s011lbl.pdf (accessed on 18 February 2020).

331. Pergolizzi, J.V.; Taylor, R.; LeQuang, J.A.; Zampogna, G.; Raffa, R.B. Concise review of the management of iatrogenic emesis using cannabinoids: Emphasis on nabilone for chemotherapy-induced nausea and vomiting. Cancer Chemother. Pharmacol. 2017, 79, 467-477. [CrossRef] [PubMed]

332. Badowski, M.E. A review of oral cannabinoids and medical marijuana for the treatment of chemotherapy-induced nausea and vomiting: A focus on pharmacokinetic variability and pharmacodynamics. Cancer Chemother. Pharmacol. 2017, 80, 441-449. [CrossRef] [PubMed]

333. Englund, A.; Morrison, P.D.; Nottage, J.; Hague, D.; Kane, F.; Bonaccorso, S.; Stone, J.M.; Reichenberg, A.; Brenneisen, R.; Holt, D.; et al. Cannabidiol inhibits THC-elicited paranoid symptoms and hippocampal-dependent memory impairment. J. Psychopharmacol. 2013, 27, 19-27. [CrossRef]

334. Schubart, C.D.; Sommer, I.E.; van Gastel, W.A.; Goetgebuer, R.L.; Kahn, R.S.; Boks, M.P. Cannabis with high cannabidiol content is associated with fewer psychotic experiences. Schizophr. Res. 2011, 130, $216-221$. [CrossRef]

335. Robson, P. Abuse potential and psychoactive effects of $\delta$-9-tetrahydrocannabinol and cannabidiol oromucosal spray (Sativex), a new cannabinoid medicine. Expert Opin. Drug Saf. 2011, 10, 675-685. [CrossRef]

336. Podda, G.; Constantinescu, C.S. Nabiximols in the treatment of spasticity, pain and urinary symptoms due to multiple sclerosis. Expert Opin. Biol. Ther. 2012, 12, 1517-1531. [CrossRef] 
337. Werth, V.; Oddis, C.V.; Lundberg, I.E.; Fiorentino, D.; Cornwall, C.; Dgetluck, N.; Constantine, S.; White, B. SAT0303 design of phase 3 study of lenabasum for the treatment of dermatomyositis. Ann. Rheum. Dis. 2019, 78, 1228-1228.

338. Corbus Pharmaceuticals. Lenabasum [Corbus Pharmaceuticals Pipeline]. Corbus Pharmaceuticals. Available online: https: / www.corbuspharma.com/our-science/lenabasum (accessed on 18 February 2020).

339. Arena Pharmaceuticals. Olorinab (APD371) [Arena Pharmaceuticals Pipeline]. Arena Pharmaceuticals. Available online: https:/ / www.arenapharm.com/pipeline/apd371/ (accessed on 18 February 2020).

340. Artelo Biosciences. ART27.13 [Artelo Development Pipeline]. Artelo Development. Available online: Http:/ / artelobio.com/pipeline (accessed on 18 February 2020).

341. Kale, V.P.; Gibbs, S.; Taylor, J.A.; Zmarowski, A.; Novak, J.; Patton, K.; Sparrow, B.; Gorospe, J.; Anand, S.; Cinar, R.; et al. Preclinical toxicity evaluation of JD5037, a peripherally restricted CB1 receptor inverse agonist, in rats and dogs for treatment of nonalcoholic steatohepatitis. Regul. Toxicol. Pharmacol. 2019, 109, 104483. [CrossRef] [PubMed]

342. Corbus Pharmaceuticals. CRB-4001 [Corbus Pharmaceuticals Pipeline]. Corbus Pharmaceuticals. Available online: https: / /www.corbuspharma.com/our-science/crb-4001 (accessed on 18 February 2020).

343. Deng, H.; Li, W. Monoacylglycerol Lipase Inhibitors: Modulators for Lipid Metabolism in Cancer Malignancy, Neurological and Metabolic Disorders. Acta Pharm. Sin. B 2019. [CrossRef]

344. Huggins, J.P.; Smart, T.S.; Langman, S.; Taylor, L.; Young, T. An efficient randomised, placebo-controlled clinical trial with the irreversible fatty acid amide hydrolase-1 inhibitor PF-04457845, which modulates endocannabinoids but fails to induce effective analgesia in patients with pain due to osteoarthritis of the knee. Pain 2012, 153, 1837-1846. [PubMed]

345. Postnov, A.; Schmidt, M.E.; Pemberton, D.J.; de Hoon, J.; Van Hecken, A.; van den Boer, M.; Zannikos, P.; van der Ark, P.; Palmer, J.A.; Rassnick, S.; et al. Fatty acid amide hydrolase inhibition by JNJ-42165279: A multiple-ascending dose and a positron emission tomography study in healthy volunteers. Clin. Transl. Sci. 2018, 11, 397-404. [CrossRef] [PubMed]

346. Kerbrat, A.; Ferré, J.C.; Fillatre, P.; Ronzière, T.; Vannier, S.; Carsin-Nicol, B.; Lavoué, S.; Vérin, M.; Gauvrit, J.Y.; Le Tulzo, Y.; et al. Acute neurologic disorder from an inhibitor of fatty acid amide hydrolase. New Engl. J. Med. 2016, 375, 1717-1725. [CrossRef]

347. Arsenault, P.; Chiche, D.; Brown, W.; Miller, J.; Treister, R.; Leff, R.; Walker, P.; Katz, N. NEO6860, modality-selective TRPV1 antagonist: A randomized, controlled, proof-of-concept trial in patients with osteoarthritis knee pain. Pain Rep. 2018, 3, e696. [CrossRef] [PubMed]

348. Gavva, N.R.; Treanor, J.J.; Garami, A.; Fang, L.; Surapaneni, S.; Akrami, A.; Alvarez, F.; Bak, A.; Darling, M.; Gore, A.; et al. Pharmacological blockade of the vanilloid receptor TRPV1 elicits marked hyperthermia in humans. Pain 2008, 136, 202-210. [CrossRef]

349. Werth, V.; Hejazi, E.; Pena, S.; Haber, J.; Okawa, J.; Feng, R.; Gabre, K.; Concha, J.; Cornwall, C.; Dgetluck, N.; et al. FRI0470 A phase 2 study of safety and efficacy of lenabasum (JBT-101), a cannabinoid receptor type 2 agonist, in refractory skin-predominant dermatomyositis. Ann. Rheum. Dis. 2018, 77, 763-764.

350. Spiera, R.; Hummers, L.; Chung, L.; Frech, T.; Domsic, R.; Hsu, V.; Furst, D.; Gordon, J.; Mayes, M.; Simms, R.; et al. OP0006 Safety and efficacy of lenabasum (JBT-101) in diffuse cutaneous systemic sclerosis subjects treated for one year in an open-label extension of trial jbt101-ssc-001. Ann. Rheum. Dis. 2018, 77, 52.

351. Marcellino, D.; Carriba, P.; Filip, M.; Borgkvist, A.; Frankowska, M.; Bellido, I.; Tanganelli, S.; Müller, C.E.; Fisone, G.; Lluis, C.; et al. Antagonistic cannabinoid CB1/dopamine D2 receptor interactions in striatal CB1/D2 heteromers. A combined neurochemical and behavioral analysis. Neuropharmacology 2008, 54, 815-823. [CrossRef]

352. Rodríguez-Muñoz, M.; Sánchez-Blázquez, P.; Merlos, M.; Garzón-Niño, J. Endocannabinoid control of glutamate NMDA receptors: The therapeutic potential and consequences of dysfunction. Oncotarget 2016, 7, 55840-55862. [CrossRef] [PubMed]

353. Musella, A.; Fresegna, D.; Rizzo, F.; Gentile, A.; Bullitta, S.; De Vito, F.; Guadalupi, L.; Centonze, D.; Mandolesi, G. A novel crosstalk within the endocannabinoid system controls GABA transmission in the striatum. Sci. Rep. 2017, 7, 7363. [CrossRef] [PubMed]

354. Haj-Dahmane, S.; Shen, R.Y. Modulation of the serotonin system by endocannabinoid signaling. Neuropharmacology 2011, 61, 414-420. [CrossRef] [PubMed] 
355. Befort, K. Interactions of the opioid and cannabinoid systems in reward: Insights from knockout studies. Front. Pharmacol. 2015, 6, 6. [PubMed]

356. Carvalho, A.F.; Van Bockstaele, E.J. Cannabinoid modulation of noradrenergic circuits: Implications for psychiatric disorders. Prog. Neuro-Psychopharmacol. Biol. Psychiatry 2012, 38, 59-67. [CrossRef] [PubMed]

(C) 2020 by the authors. Licensee MDPI, Basel, Switzerland. This article is an open access article distributed under the terms and conditions of the Creative Commons Attribution (CC BY) license (http://creativecommons.org/licenses/by/4.0/). 